Florida International University FIU Digital Commons

12-9-2009

\title{
Resource, Strategies, Location Determinants, And Host Country Location Choice By Emerging Market Firms
}

Naveen K. Jain

Florida International University, njain001@fiu.edu

DOI: $10.25148 /$ etd.FI10041615

Follow this and additional works at: https://digitalcommons.fiu.edu/etd

\section{Recommended Citation}

Jain, Naveen K., "Resource, Strategies, Location Determinants, And Host Country Location Choice By Emerging Market Firms" (2009). FIU Electronic Theses and Dissertations. 147.

https://digitalcommons.fiu.edu/etd/147 


\section{FLORIDA INTERNATIONAL UNIVERSITY}

Miami, Florida

RESOURCES, STRATEGIES, LOCATION DETERMINANTS, AND HOST COUNTRY LOCATION CHOICE BY EMERGING MARKET FIRMS

A dissertation submitted in partial fulfillment of the

requirements for the degree of

DOCTOR OF PHILOSOPHY

in

BUSINESS ADMINISTRATION

by

Naveen Kumar Jain

2010 
To: Dean Joyce Elam

College of Business Administration

This dissertation, written by Naveen Kumar Jain, and entitled Resources, Strategies, Location Determinants, and Host Country Location Choice by Emerging Market Firms, having been approved in respect to style and intellectual content, is referred to you for judgment.

We have read this dissertation and recommend that it be approved.

Juan Sanchez

William Newburry

Kaushik Dutta

Torben Pedersen

Sumit K. Kundu, Major Professor

Date of Defense: December 9, 2009

This dissertation of Naveen Kumar Jain is approved.

Dean Joyce Elam College of Business Administration

Dean George Walker University Graduate School

Florida International University, 2010 


\section{DEDICATION}

I dedicate this thesis to my parents, Lal Chand Jain and Sheela Jain; my sister Niti Jain; and my wife, Shefali Jain. Without their patience, understanding, support, and most of all love, the completion of this work would not have been possible. 


\section{ACKNOWLEDGMENTS}

I wish to thank the members of my committee for their support, patience, and good humor. Their gentle but firm direction has been most appreciated. Dr. Juan Sanchez, Dr. William Newburry, Dr. Torben Pedersen were particularly helpful in guiding me towards theory-building and qualitative methodology. Dr. Kaushik Dutta provided me software industry specific guidance that helped me in data collection. Dr. James Jaccard helped me with methodology. Finally, I would like to thank my major professor, Dr. Sumit K. Kundu. From the beginning, he had confidence in my abilities to not only complete a degree, but to complete it with excellence.

I have found my coursework throughout the Curriculum and Instruction program to be stimulating and thoughtful, providing me with the tools with which to explore both past and present ideas and issues. 


\title{
ABSTRACT OF THE DISSERTATION \\ RESOURCES, STRATEGIES, LOCATION DETERMINANTS, AND HOST COUNTRY LOCATION CHOICE BY EMERGING MARKET FIRMS
}

by

\author{
Naveen Kumar Jain
}

Florida International University, 2010

Miami, Florida

Professor Sumit K. Kundu, Major Professor

The extant literature had studied the determinants of the firms' location decisions with help of host country characteristics and distances between home and host countries. Firm resources and its internationalization strategies had found limited attention in this literature. To address this gap, the research question in this dissertation was whether and how firms' resources and internationalization strategies impacted the international location decisions of emerging market firms.

To explore the research question, data were hand-collected from Indian software firms on their location decisions taken between April 2000 and March 2009. To analyze the multi-level longitudinal dataset, hierarchical linear modeling was used. The results showed that the internationalization strategies, namely market-seeking or labor-seeking had direct impact on firms' location decision. This direct relationship was moderated by firm resource which, in case of Indian software firms, was the appraisal at CMMI level-5. Indian software firms located in developed countries with a market-seeking strategy and in emerging markets with a labor-seeking strategy. However, software firms with resource such as CMMI level-5 appraisal, when in a labor-seeking mode, were more likely to locate in a developed country over emerging market than firms without the appraisal. Software firms with CMMI level-5 appraisal, when in market-seeking mode, were more likely to locate in a developed country over an emerging market than firms without the appraisal.

It was concluded that the internationalization strategies and resources of companies predicted their location choices, over and above the variables studied in the theoretical field of location determinants. 
TABLE OF CONTENTS

$\begin{array}{ll}\text { CHAPTER } & \text { PAGE }\end{array}$

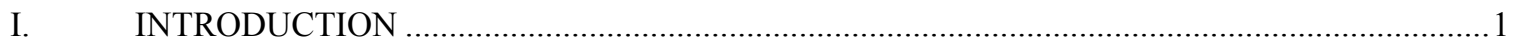

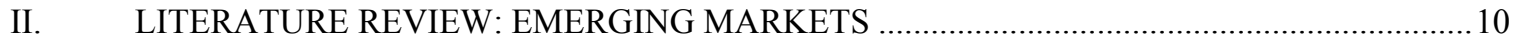

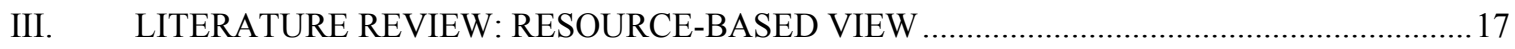

IV. LITERATURE REVIEW: INTERNATIONALIZATION STRATEGIES ...................................29

V. LITERATURE REVIEW: DETERMINANTS OF HOST COUNTRY

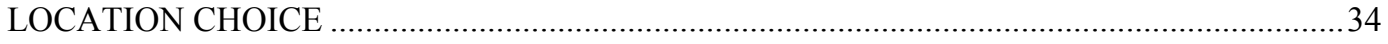

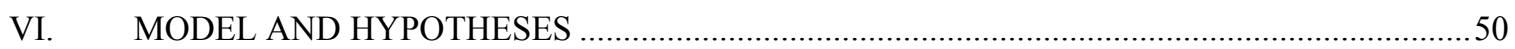

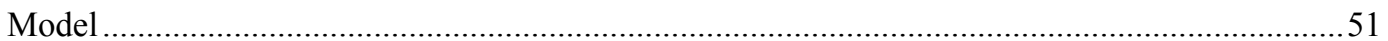

Internationalization Strategies and Location Choice of Indian Software Firms...............................53

Electronic Knowledge Sharing Database as a Resource and Location Choice ................................56

Low Cost of Software Production as a Resource and Location Choice ...........................................58

Process Improvement Implementation as a Resource and Location Choice ...................................60

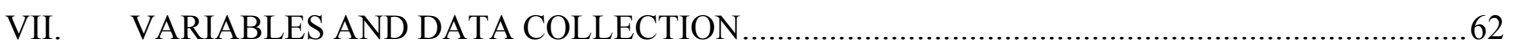

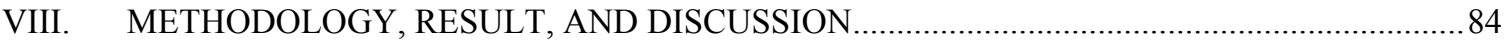

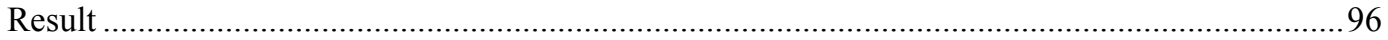

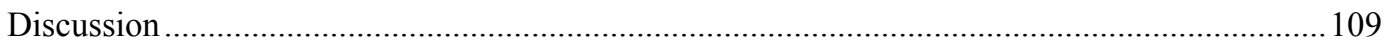

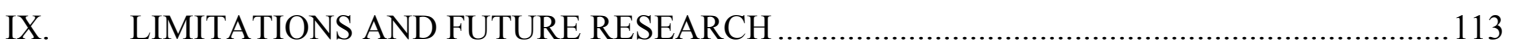

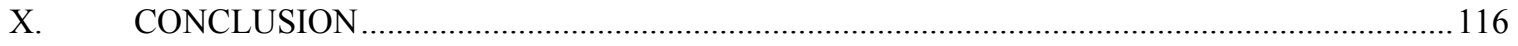

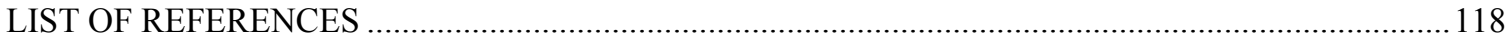

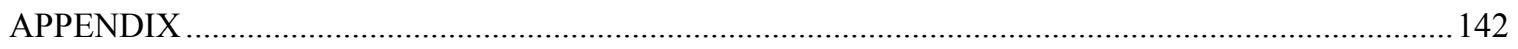

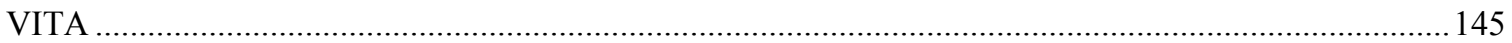




\section{LIST OF TABLES}

TABLE

PAGE

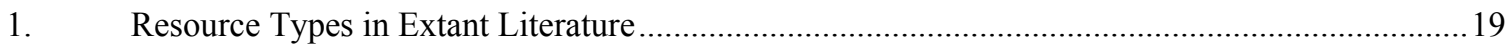

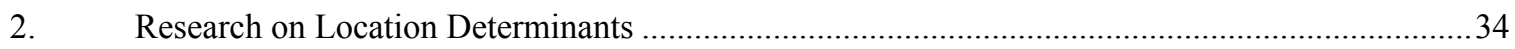

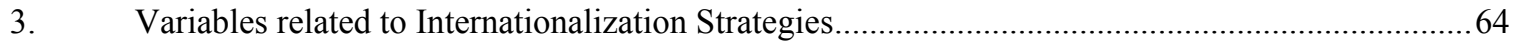

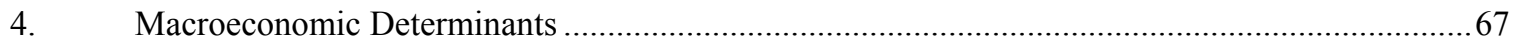

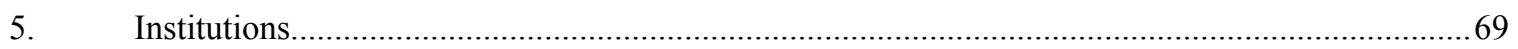

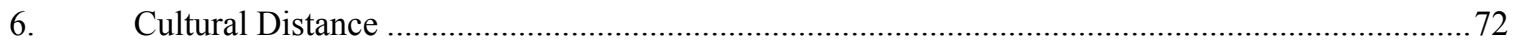

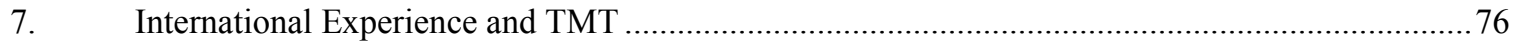

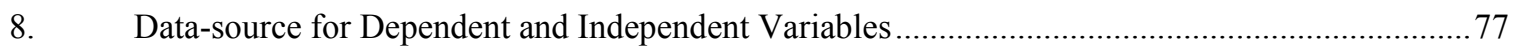

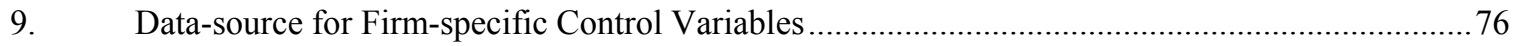

10. Data-source for Host Country-specific Control Variables ........................................................... 76

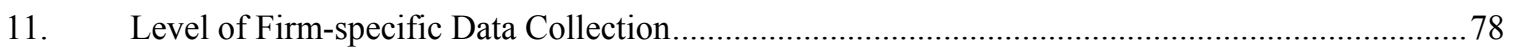

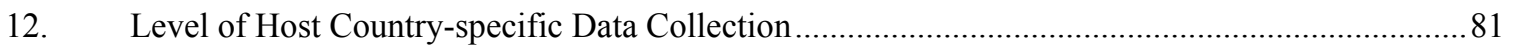

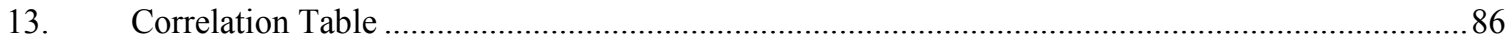

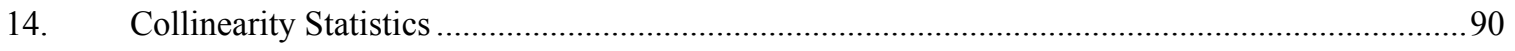

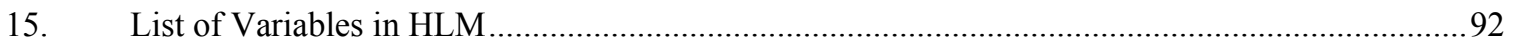

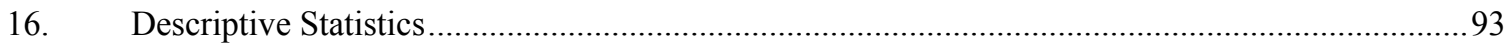

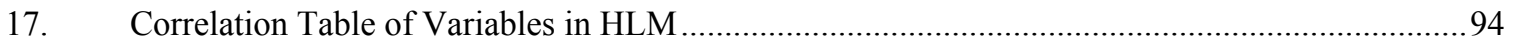

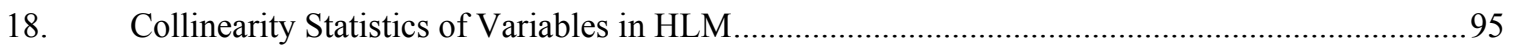

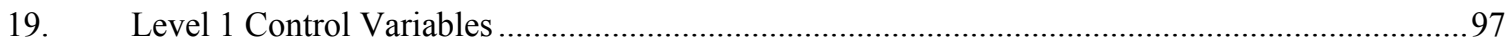

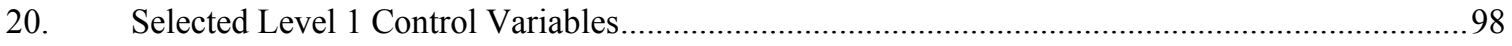

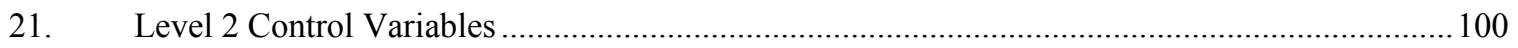

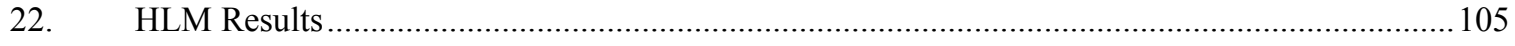

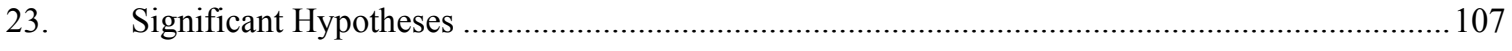




\section{CHAPTER I}

\section{INTRODUCTION}

As multinational firms engage in two-way knowledge flows between parents and subsidiaries in order to enhance their competitive advantage, subsidiary location choice is gaining managerial attention (Dunning, 1998, 2009). Multinational firms no longer consider a location merely as a financial risk reduction tool (Dunning, 2009; Rugman, 1979), but use it as an asset sourcing means capable of enhancing their competitive advantage by creating a coherent set of locations that fit well with each other (Dunning, 2009; Ghemawat, 2001; Ricart, Enright, Ghemawat, Hart, \& Khanna, 2004). Location, as a factor, affects multinationals' market valuations (Pantzalis, 2001). It is not surprising that the multinational managers, equipped with information made available to them by advanced communication and technological tools (Ricart et al., 2004), are making sophisticated decisions about slicing the activities of firms more finely and spreading them more thinly to international locations more apt to undertake these activities (Buckley \& Ghauri, 2004; Ricart et al., 2004). Although location choice seems to be an important strategic decision, it still remains an under-studied area in field of International Business (IB) (Buckley, Devinney, \& Louviere, 2007; Cantwell, 2009; Dunning, 1998; Dunning, 2009; Mudambi \& Navarra, 2003).

Location, though a central point of discussion in IB literature in the 1960's (for example, Vernon's Product Life Cycle theory in 1966), lost ground as scholars shifted their attention to the firm and its strategies in the 1970's and 1980's. Location reemerged as a factor to consider in the 1990's in a changed world order that includes increasing globalization, increased competition, interconnectedness of activities, alliance capitalism, technological breakthroughs, and use of intellectual property as a central resource for internationalization (Dunning, 2009). Realizing this, scholars began to study country effects and showed them to positively contribute towards the growth and profitability of a multinational's affiliate above and beyond the effects of firm, business unit and industry (Brouthers, 1998; Christman, Day, \& Yip, 1999; Makino, Isobe, \& Chan, 2004, Tong, Alessandri, Reuer, \& Chintakananda, 2008).

For an emerging market firm (EMF) which, in general, possesses limited resources compared to its developed country brethrens, choice of host country locations may be part of an important strategy because the country and industry effects are shown to be even more salient than the firm and business unit 
effects in case of EMFs (Makino, Isobe, \& Chan, 2004). Consequently, an optimum host country location may enhance an EMF's resource base, competitive advantage and profitability (Perez-Batres \& Eden, 2008; Vermeulen \& Barkema, 2002). Thus, it becomes important to study the location choices of EMFs which have been internationalizing at a rapid pace; and are posed to internationalize further, as institutional reforms unfold in emerging markets (Child \& Tse, 2001). In recent times, outward FDI from developing and transition economies reached a record high of US\$ 304 billion (UNCTAD, 2008). At the same time, international sales from emerging markets aggregated to approximately US\$ 1.9 trillion with worldwide employment increasing to 6 million people (UNCTAD, 2006). Despite these advances by EMFs, knowledge about management outside North America is still lacking in both quality and quantity (Tsui, 2007; Werner, 2002).

The research question, namely location choices of EMFs, raised in this dissertation assumes importance because of manifold reasons. First, scholars have started to investigate only recently as to why and when firms from developing and newly-industrialized countries invest in other countries (Chen \& Chen, 1998; Lecraw, 1993), and how their location determinants differ from those of the developed country firms (Kimura \& Lee, 1998). However, consensus on these issues is still elusive and requires systematic conceptual and empirical investigations (Makino, Lau, \& Yeh, 2002). Second, the theories developed in North America vary in degree of their applicability to emerging markets and require significant adjustments before they can be used to study and interpret the processes of EMFs due to differences in social, cultural, political, legal and economic systems in the two sets of countries (Hofstede, 2007; Li, 2004; Shenkar \& Von Glinow, 1994). Third, the resource advantages and internationalization processes of EMFs differ from those of developed country firms (Curevo-Cazurra, 2008; Dunning, 2000).

The impact of a firm's resources on its international location decision does not seem to be wellexplored, though there exists a well-developed literature on host country location choice; and though, firm resources have long been shown to contribute towards the internationalization of both traditional and virtual firms initially or subsequently in a host country (Bogner, Thomas, \& McGee, 1996; Dunning, 1980; Hitt, Bierman, Shimizu, \& Kochhar, 2001; Hymer, 1976; Kotha, Rindova, \& Rothaermel, 2001). The relationship between firm's resources and internationalization has been observed for EMFs as well 
(Chittoor, Sarkar, Ray, \& Aulakh, 2009). However, we know only a little about the relationship between specific resource types and their impact on firms' internationalization (Hitt, Bierman, Uhlenbruck, \& Shimizu, 2006). One such relationship between resources and internationalization that we are aware of is that different types of resources impact differently the international performance of a multinational, with human resources positively moderating the relationship between internationalization and firm performance, while foreign government relational resources negatively moderating the relationship in case of services firms (Hitt et al., 2006).

The resource-based view of the firm states that firms are heterogeneously endowed with different resources. Since different types of resources impart different exploitative abilities to firms and since different resources are fungible to varying degrees when applied to a different environment (Miller \& Shamsie, 1996; Ricart et al. 2004), it is highly likely that a diverse set of firm's resources may differentially affect its international location choices because a host country may have a set of economic, institutional, social, and competitive environments that are different from the home country of the firm. Given differences in factor endowments, demand conditions and competition levels between home and host country; a firm's resources can become either advantageous or disadvantageous in a host country (CurevoCazurra et al., 2007; Caves, 1996; Dunning, 1995; Itaki, 1991; Teece, 1977; Zaheer, 1995) because the advantages provided by resources are relative to the competitive environment in which the firm operates (Amit \& Schoemaker, 1993; Miller \& Shamsie, 1996; Tallman, 1991). This indicates that resources may be important determinants of firms' location decisions. For example, Japanese firms that developed resources such as engineering and sourcing capabilities stayed in Taiwan and Singapore when wage hikes occurred in these two countries, while others that did not possess these resources had to relocate to Malaysia and Thailand (Song, 2002). Similarly, the U.S. firms that had higher R\&D intensity and a greater proportion of overseas sales located in Israel while others that did not have these specific resources chose to locate in other parts of Middle-East (Fiegenbaum, Shaver, \& Yeung, 1997).

Moreover, a firm's resources lead it to adopt certain strategies (Prahalad \& Hamel, 1990) and an optimum combination of resources and strategies generates sustainable competitive advantage for a firm (Barney \& Arikan, 2001). A firm endowed with different resources may adopt different international 
strategies to match the environment in a country and be more competitive there (Kraatz \& Zajac, 2001). Thus, a firm may locate in different host countries with different international strategies. Hence, it is probable that a firm's international strategy, besides its resources impacts its location decision. To understand the impact of an EMF's resource-types and international strategies on its international location decision, this dissertation makes a preliminary effort to identify, segment and categorize various types of resources possessed by EMFs and in the process, makes yet another contribution to the present literature. The dissertation makes several other contributions as discussed below.

First, the study seeks to fill a gap in the IB literature by combining the literature on MNC's resources and strategies with the literature on IB location choice. Scholars such as Werner (2002) and Ricart et al. (2004) identify MNC's strategies as an area of future research in IB. Peng (2001) reviewed the use of resource-based view, one of the key developments in the area of strategy, in the field of IB between years 1991- 2000 and found five IB areas, namely strategic alliance, market entry, international entrepreneurship, emerging market strategies, and multinational management, where resource-based view has been used. Peng's (2001) study highlights the lack of work in integrating the strategy with location literature. In fact, in my limited literature review, I came across only a few scholarly pieces, for example, Xu and Shenkar (2002) and Makino et al. (2002) that examine the joint impact of resource type and internationalization strategies on location choice of emerging market multinational firms. Henisz and Macher (2004) suggest that the levels of firms' technological capabilities affect their host country location decisions. Yang, Jiang, Kang, and Ke (2009) conduct case studies of a Japanese (Matsushita) and a Chinese (Haier) firm to study the joint impact of firm's resources, industrial characteristics, and institutional environments on internationalization of these two firms. In another study, Tseng, Tansuhaj, Hallagan, and McCullough (2007) study how knowledge and property-based resources lead to different patterns of growth in multinationality. Thus, it is not puzzling that combining strategy with IB is a potential area of future research, at the least in location literature. Adopting the same approach as past scholars (had) who combined strategy with IB field with help of resource-based view (Peng, 2001), this dissertation also uses resource-based view to combine the two fields. Combining IB and strategy fields in the context of emerging markets has been recognized as a prospective research area (Peng, 2001). 
Second, the question of host country location choice, given an EMF's resource base and possible strategies, assumes both scholarly and managerial significance because the performance of EMFs in host country depends upon how well they are able to transfer their competences from the home base (Child, Chung, \& Davies, 2003). A hostile foreign environment may dissipate the already scant resources of an EMF and render it non-competitive in the market-place.

Third, by combining country factors with firm resources and strategies, the dissertation makes an attempt to integrate different levels of analyses in line with the suggestions made to study location related research by adopting a multilevel approach (Enright, 2002; Ricart et al., 2004). In general, multilevel research is recommended in order to enrich the future research in field of IB (Arregle, Hebert, \& Beamish, 2006; Hitt, Tihanyi, Miller, \& Connelly, 2006) and management at large (Hitt, Beamish, Jackson, \& Mathieu, 2007).

Fourth, a multilevel approach has potential to generate a comprehensive model of location choice. A comprehensive model would enhance our understanding of the location literature because there are several competing theories explaining a number of plausible determinants considered by firms in making a location decisions, for example Agglomeration externalities (Almeida, 1996; Porter, 2000; Saxenian, 1996; Smith \& Florida, 1994), Institutional and Political Distance (Delios \& Henisz, 2000; Henisz, 2000; Hillman, 2005; Nigh, 1985; Tallman, 1988;), Internationalization Process (IP) model (Johanson \& Vahlne, 1977; Johanson \& Weidersheim-Paul, 1975), Network Linkages (Bandelj, 2002; Chen, Chen, \& Ku, 2004; Filatotchev, Strange, Piesse, \& Lien, 2007; Johanson \& Vahlne, 1990), OLI paradigm (Dunning, 1988), and Oligopolistic Reaction (Flowers, 1976; Knickerbocker, 1973; Yu \& Ito, 1988). Besides these theories, the firm resources (Dunning, 1983; Hymer, 1976) and firm strategies (Dunning, 1983) are also said to impact the internationalization process of multinational firms. However, there is no framework which makes an attempt to simultaneously study these competing but plausible explanations.

Fifth, a comprehensive model that is able to combine at least some of these different viewpoints to study the host country location choice by the emerging market multinational firms will have beneficial implications for managers because these above-mentioned competing viewpoints may guide them to choose different host country locations. In the process, the managers may end up making a sub-optimal 
location choice and may detrimentally spread the firm's resources too thin. For example, if managers use the theories put forth in the field of economic geography to guide the firm's location decision, they may like to augment the EMF's limited resources (when compared with their developed country counterparts) by venturing out to those geographic locations that provide network externalities irrespective of the distance between their home country and the geographic clusters in the host country. At the same time, an examination grounded in Network Linkages may suggest them that the firms should follow the IP model, as ethnic community which is a very important source of network linkage, largely, remains concentrated in areas bordering the home country of firms (Chen \& Chen, 1998). On the contrary, an analysis of location decisions of firms based on Institutional Distance may provide mixed support, contingent upon the extent of government regulations in the industry of internationalizing firms (Canal-Garcia \& Guillen, 2008). The IP-model and the OLI paradigm will also expect managers to make different country choices and may create a dilemma in reconciling the guidance of the two models (Curevo-Cazurra, 2008). No wonder, Buckley et. al (2007) found that the managers appeared to follow fairly rational rules and fundamental operational factors in creating sets of location alternatives but their final choice aligned more with countryspecific factors and less with traditional theoretical models.

Sixth, there have been calls by scholars to conduct further empirical research in the resource-based view (Armstrong \& Shimizu, 2007). This empirical dissertation indirectly fills that gap by drawing upon the resource-based view to understand the location choice of EMFs.

Last but not the least; the dissertation indirectly examines, by studying the location patterns of EMFs, whether an internationalizing EMF is constrained by "distance" while selecting a host country. Distance is said to be one of the important location determinants considered by multinationals while making their location decisions (Johanson \& Vahlne, 1977). EMFs are said to be less risk-averse and less guided by psychic, cultural, geographic and economic distances (Bonaglia, Goldstein, \& Mathews, 2007; Luo \& Tung, 2007). A cursory look at the location choices of many EMFs from China, Mexico, Brazil, or India suggests, though, a mixed support for the distance paradigm, indicating a need for further investigations to explain the location choices of EMFs. There are only limited empirical studies exploring this issue in context of EMFs which are in their initial stage of internationalization process, and hence 
provide an interesting natural setting to test the distance paradigm proposed by Johanson and Vahlne (1977). This insight would gain further importance as Dunning (2009) observes that location is now a more complex decision than the one proposed in IP model.

To explore the research question raised here, an extensive review of literature on emerging markets, resource-based view, internationalization strategies, and determinants of location choice is undertaken to study the relationship between an emerging market firm's resources and strategies, and its international location choice. The dissertation combines these theories by employing the eclectic paradigm of international production (Dunning \& Lundan, 2008). This framework has been employed to study similar research questions such as the choice of location by multilatinas (Cazzura, 2008). The eclectic paradigm of international production combines MNC's various international strategies such as marketseeking, asset-seeking, efficiency-seeking, and resource-seeking with the OLI paradigm to explain reasons for international production. The emphasis of the OLI paradigm, though, is to explain why a firm becomes multinational. The paradigm explicates that when a firm internalizes its ownership-specific advantages (which are both resources of a multinational firm and its transaction-specific advantages) and interacts them with the location-specific advantages of a host country, it becomes multinational (Dunning \& Lundan, 2008). Because the eclectic paradigm of international production incorporates the interaction of all independent variables used in this dissertation, namely firm's unique resources (which mean only assetspecific and not transaction-specific advantages in the dissertation), its international strategies, and location determinants, the framework is suitable to study this dissertation topic.

Another choice, to analyze the research question, may be the contingency based approach. As per contingency theorists such as Lawrence and Lorsch (1967), Donaldson (2001), Drazin and Van de ven (1985), and Miller (1981); a fit among resources, strategies and country selection is necessary to result in a superior firm performance. Contingency theory emphasizes the role of firm resources, managerial strategies, and environment towards firm performance. Though, the roles of environment, firm strategies and a fit between the two have been validated in context of emerging markets (Child et. al, 2003); the emphasis of the contingency approach is on superior firm performance as a dependent variable. Since the 
dependent variable in this dissertation is host country location, the eclectic paradigm of international production is better suited to explain the model proposed in the dissertation.

IP model is yet another frequently used model to explain the host country location decisions. But its emphasis is more on distance as a location determinant. As the dissertation incorporates various levels of analysis and makes an attempt to present a comprehensive model, the choice of IP model is not very suitable for the research question raised in the dissertation.

Figure 1 summarizes the conceptual model proposed in the dissertation. In the model, it can be observed that resource types of EMFs determine its internationalization strategies, which in turn, affect location decision of EMFs, after controlling for other host country location determinants. The direct relationship between the internationalization strategies and international location choice is proposed to be moderated by the resource types of EMFs.

Figure 1: Conceptual Model

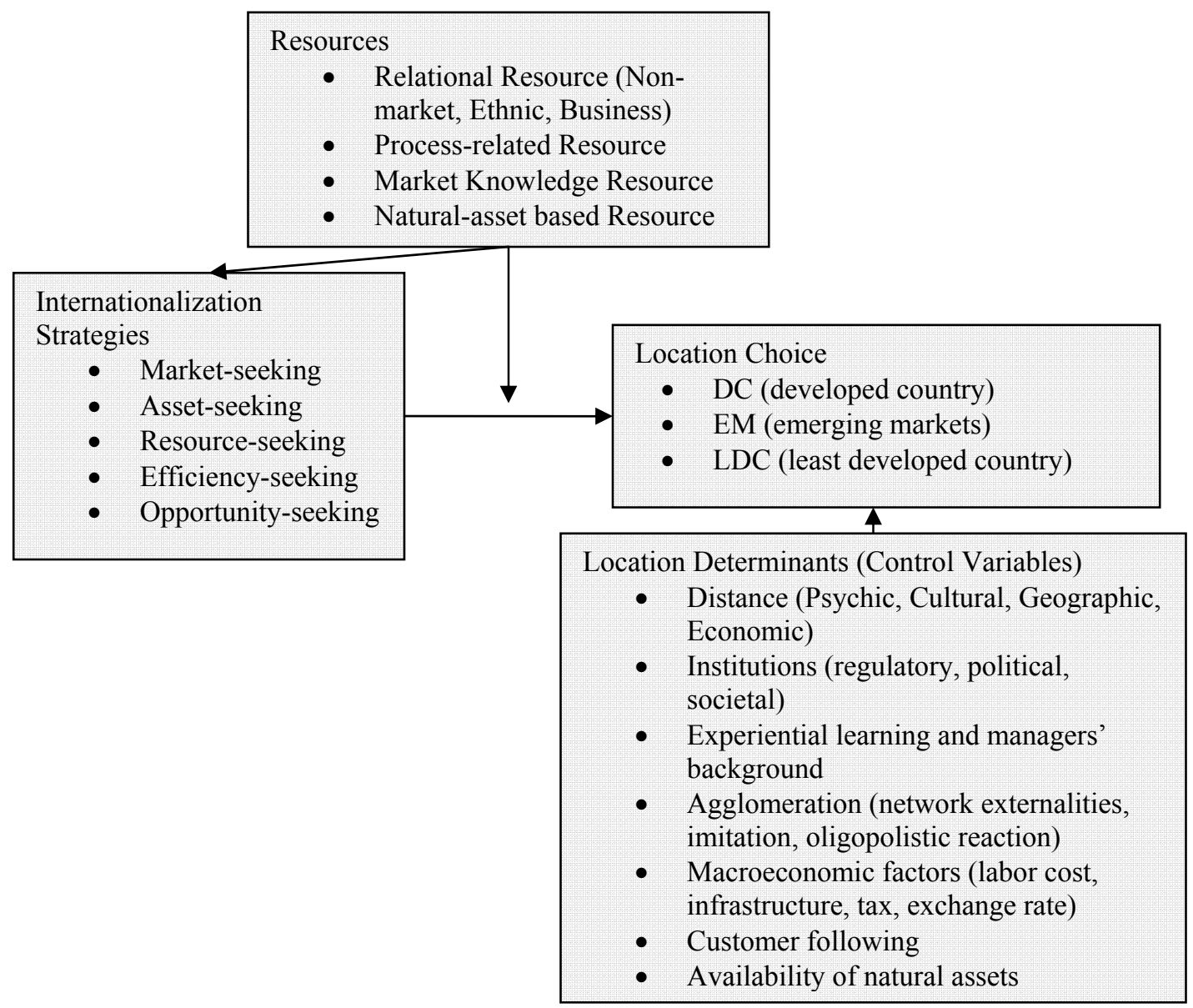


The dissertation draws upon survey-based and archival data from Indian software firms to examine the proposed model. The emphasis by Indian government on education has created a large supply of highlyskilled labor force available at rather cost-competitive rates. Some Indian firms, especially the software firms, have used this country-created asset to internationalize by developing process-based resources. The high quality of the talent has led these firms to offer low-cost process-related solutions to their customers and have helped the former go international. So, the dissertation studies how process-related resources and the internationalization strategies of firms affect their location choices and empirically examines this relationship in context of Indian software firms.

Given the overall model, I carry out a review of the literature that has bearing upon the model. The literature review is divided into chapters 2-5. In chapter 2, a review of the literature on emerging markets and EMFs is conducted. In chapter 3, a literature on Resource-based-view is detailed. In chapter 4, a review of internationalization strategies is carried out; and chapter 5 makes an effort to explain the scholarly work on host country location determinants. 


\section{CHAPTER II}

\section{LITERATURE REVIEW: EMERGING MARKETS}

A review of literature on emerging market is necessitated as the context of the dissertation is set in an emerging market, namely India. As western theories have limited applications in emerging markets (Shenkar \& Von Glinow, 1994), it is important to review this literature to understand the nuances of emerging markets and how these affect EMFs.

The term “emerging markets" has been brought to surface by the World Bank in 1980's (Wikipedia). As per the literature, the defining characteristics of emerging markets are as follows:

- low-income but rapid economic growth coming from liberalization of their economies (Luo, 2002; Meyer, 2004), offering local firms a high-risk but high-return business environment (Makino, Beamish, \& Zhao, 2004);

- evolving regulatory, political and societal institutions on an already existing base of some institutions that promote commerce (Gelbuda, Meyer, \& Delios, 2008; Khanna \& Palepu, 1997);

- $\quad$ an economic environment, which is hostile (i.e. importance and deterrence of environmental factors), dynamic (i.e. predictability and variability of environmental factors), and complex (i.e. diversity and heterogeneity of environmental factors) (Luo \& Peng, 1999; Tan \& Litschert, 1994);

- $\quad$ volatile economic policies with a gradual move towards paring down of government intervention in the economy with an aim to move towards free market economic system;

- unstable political scenario that has increased industrial and strategic uncertainties for local and foreign firms (Hoskison, Eden, Lau, \& Wright, 2000; Luo, 2002; May, Stewart, \& Sweo, 2000; Peng \& Luo, 2000) and slowed inward FDI (Petersen \& Pedersen, 1999);

- weak legal framework resulting in high measurement and enforcement costs leading to high transaction costs (Choi, Lee, \& Kim, 1999; Hoskisson et al., 2000; Khanna \& Palepu, 1997; Xin \& Pearce, 1996);

- $\quad$ coexistence of both market mechanism (i.e. allocation of resources by market forces) and redistributive mechanism (i.e. allocation of resources by the government) (Zhou, 2000);

- $\quad$ missing well-defined property rights resulting in less competitive firms (Makino et. al, 2004); 
- rampant corruption, bribery, rent-shifting and opportunism (Hoskisson et al., 2000; Nelson, Tilley, \& Walker, 1998;), making enforcement of laws a big concern even when laws have been enacted and government connections are pursued (Choi et. al, 1999; Hoskisson et al., 2000; Khanna \& Palepu, 1997); and hence turning the competitive environment dysfunctional in emerging markets (Li \& Zhang, 2007);

- less competitive and smaller market-size with fewer resource-endowed firms (Aulakh, Kotabe, \& Teegen, 2000; Ghemawat \& Khanna, 1998; Sol \& Kogan, 2007);

- fewer location advantages based on created assets such as infrastructure and human capital (Hoskisson et al. 2000, Narula \& Dunning, 2000; Meyer, 2004) but more location advantages based on natural assets (Dawar \& Frost, 1999; Aulakh et al., 2000);

- less developed intermediaries like thin capital markets, shortages of skilled labor, underdeveloped factor and product markets, and infrastructural bottlenecks resulting in high financial and transformation costs for firms (Hong, 2004; Liu \& Li, 2002; Khanna \& Palepu, 1997; Meyer, 2004; Tan \& Litschert, 1994; Wan, 2005; Wright, Filatotchev, Hoskisson, \& Peng, 2005; Xin \& Pearce, 1996);

- less mature financial markets making firms escape with inadequate disclosures, weak corporate governance and control (Khanna \& Palepu, 2000), and leading to a longer sustenance of poorly performing firms (Chacar \& Vissa, 2005) than in efficient capital markets of developed countries where poorly performing firms are weeded out (Wan, 2005);

- stronger societal influences and relationship-oriented culture (Hong, 2004; Hoskisson et al., 2000; Luo \& Peng, 1999); making managerial networking important in emerging markets but using it to overcome fundamental threats such as extortion or expropriation rather than to obtain customers, market information or secure credits as in developed markets (Henisz \& Zelner, 1999; Xin \& Pearce, 1996);

- General suspicion of stakeholders such as government, suppliers and customers towards foreign firms (Hoskisson et al., 2000) requiring foreign firms to have a long presence (Child, 1997; Luo \& Peng, 1999) or local community involvement (Gifford \& Kestler, 2008) to gain legitimacy. 
Based on these characteristics; it may be suggested that the emerging markets lie somewhere in between the least developed economies and the developed economies. Hoskisson et al. (2000) identify a total of sixty-four emerging markets (appendix 1) categorized into two groups - fifty one developing economies in Africa, Asia, Latin America, Middle East (the same as identified by International Finance Corporation - IFC); and thirteen transition economies in erstwhile USSR block and China. However, all these countries do not form a homogeneous set. There are differences among emerging markets due to different pace of their economic and institutional reforms (Wright et al. 2005), and social cultures. For example, institutions are changing slowly in Gulf Cooperation Council economies (Kshetri \& Ajami, 2008). Consequently, even the gains from the economic and institutional changes have not been uniform across emerging markets (Hoskisson et al., 2000). For example, inward FDI and organizational learning in different emerging markets have varied from a high level in countries such as China, India to a low level in countries such as Baltic States and Russia (Hitt, Ahlstrom, Dacin, Levitas, \& Svobodina, 2004; Jansson \& Sandberg, 2008).

Asian countries of Hong-Kong and Singapore, which are normally termed as Newly Industrialized Countries (NICs) are categorized as developed countries in the dissertation. NICs have high created asset environments or advanced institutional environments (Wan, 2005), which may have led to differences between EMFs and NIC firms. For example, the developed institutions in NICs have resulted in fewer business groups, but more market-oriented and less diversified firms (Chakrabarti, Singh, \& Mahmood, 2007; Guillen, 2000; Lee \& Slater, 2007; Pananond, 2007; Wan, 2005). NIC firms depend more on ethnic ties than EMFs in their internationalization efforts (Chen, 2003; Mathews, 2002). Hence, it is appropriate to club NICs together with developed countries than emerging markets.

The literature on emerging markets can be divided into two phases with a first wave developed around the early 1980's by scholars such as Fagre and Wells (1982), Kumar \& McLeod (1981), Lall (1983), and Lecraw (1983), among others. These scholars used the term developing countries, though, and not emerging markets. The second phase began in late 1990's and continues to date. In between these two phases, there were occasional scholarly pieces in the early 1990's (Cantwell, 1989; Erramilli, 1992; Hu, 
1995; Kumar, 1994; Lecraw, 1993; Lee \& Beamish, 1995; Tan \& Litschert, 1994; Tolentino, 1993; Woodward \& Rolfe, 1993).

Fagre and Wells (1982) linked various characteristics of a USA, European or Japanese transnational corporation (TNC) such as size, intrafirm transfers, advertising, R\&D intensity, and product diversity to their extent of equity ownership in their affiliates in the developing countries. Lecraw (1983) extended the literature by suggesting that the host developing countries too possessed some bargaining power vis-à-vis TNCs and conducted an empirical study of USA, European and Japanese firms' investment in five ASEAN (Indonesia, Thailand, Malaysia, Singapore, Philippines) host countries. He proposed that the characteristics of the host country and those of a TNC influence the TNC's ownership percentage in its subsidiaries (Lecraw, 1983). He found that the bargaining power of these host countries came from the possession of scarce resources or the ability to control access to their markets. On the contrary, a TNC gained advantage over the host country and entered through an FDI route if the TNC had a big brand name, high marketing or management skills, technological products or could provide its subsidiary with inexpensive financial capital. Lecraw (1983) found a J-shaped relationship between a TNC's equity ownership in its affiliate and the TNC's perception of its affiliate's success. Lall (1983) proposed that developing country firms internationalized by exporting their products to other developing countries and the least developed countries, but did not export to developed countries. These exporting firms possessed low cost advantage and had developed efficient mass production technologies (Lall, 1983).

The first phase of the literature on internationalization of EMFs developed in pre-globalization era, but the second phase of the literature development coincided with the globalization era which represents a different phenomenon altogether, and which also changed the determinants of host country selection (Dunning, 1998). Globalization era saw many countries liberalizing their economies, firms forming crossborder alliances, and information flowing without asymmetry (Dunning, 2009). No wonder, scholars such as Luo and Tung (2007) suggest that the analysis of the internationalization of EMFs in globalization era requires a new perspective different from the pre-globalization era since the emerging market multinationals of today are much less path-dependent and much more risk-taking than the third world MNCs of 1980's, though still sharing some basic strengths like cost advantages and weaknesses like 
limited knowledge of international markets. The internationalization of EMFs in the globalization era is driven less by cost factors; and more by search for markets and technological innovations to compete successfully globally. These firms utilize pull factors and connections to accelerate internationalization (Mathews, 2006). Moreover, the determinants of host country location choice seem to be changing with some factors like population becoming more salient in 2000 than in 1980 (Flores \& Aguilera, 2007). Consequently, this dissertation utilizes more the literature in the second phase written after mid 90's.

The literature witnessed a spurt of scholarly interest in emerging markets (especially in China) in the second phase. There have been many dedicated sessions on emerging markets in leading journals such as Academy of Management Journal (2000), Journal of Management Studies (2005), Journal of International Business Studies (2007) and Journal of International Management (2007), to name a few. Most of the studies in these dedicated volumes have used institutional theory, transaction cost economics or resource based view or their combination to understand the nuances of emerging markets and how these idiosyncrasies affect the economic, institutional, societal and resource environments in emerging markets and their impact on development, operations and survival of local firms and foreign firms (Luo \& Peng, 1999; Peng \& Heath, 1996; Shenkar \& Von Glinow, 1994; Suhomlinova, 2006). Further detailing is given in the following paragraphs.

The constrained local environment replete with institutional voids and high transaction costs in emerging markets has led some EMFs to develop unique hybrid organizational structures such as business groups and interfirm networks (Hoskisson et al., 2000; Khanna \& Palepu, 1997; Peng \& Heath, 1996).

Other ownership types in emerging markets are state-owned-enterprises (SOEs), privatized firms, entrepreneurial-led firms and foreign entrants (Peng, 2003). Business groups, themselves, can be of three types, namely family-owned, widely-held, and state-owned (Curevo-Cazurra, 2006).

Business groups and network-based structures help these EMFs overcome weaker legal institutions by promoting trust-based transactions among member firms or using network resources to enforce a contract, thereby arresting the fear of opportunistic attempt in a transaction (Guillen, 2000; Khanna \& Palepu, 1997). Other usages of membership are access to intangible and financial resources residing within the group or network (Chang \& Hong, 2000; Khanna \& Palepu, 1997; Makhija, 2004) or with its foreign partners who 
team with the business group or network to access the governments or market-specific knowledge in emerging markets (Lee \& Beamish, 1995; Leff, 1978; Khanna \& Palepu, 2000; Meyer \& Nguyen, 2005). These groups or networks develop reputational capital and become attractive partners for foreign multinationals desirous of launching their operations in an emerging market (Lu \& Ma, 2008; Pan \& Chi, 1999), thereby gaining access to the superior technological and managerial skills of their multinational partners (Leff, 1978; Luo \& Tung, 2007; Khanna \& Palepu, 2000). Foreign firms, despite contributing critical resources, are willing to maintain a balance in management control, in order to enhance the survival of the venture in emerging economies (Karhunen, Lofgren, \& Kosonen, 2008; Lee, Chen, \& Kao, 1998; Steensma \& Lyles, 2000).

But with more market-oriented economic and institutional reforms sweeping through in emerging markets, many business group or network affiliated EMFs face obsolescence in their resource set as what was important earlier may not be so important under the more market-oriented environment (Wright et al., 2005). Business groups are observed to loose their advantage over other competitors (Hoskisson et al., 2000), and even as joint venture partners procuring scarce resources for foreign multinational firms (Khanna \& Rivkin, 2006; Meyer, Estrik, Bhaumik, \& Peng, 2008). The impact of managerial non-market resources on business performance is contingent upon intensity of competition, growth rate and structural uncertainty in the business environment, with a weaker influence on performance under competitive and growing environment with decreasing structural uncertainty (Li, Poppo, \& Zhou, 2008; Peng, 2003; Peng \& Luo, 2000) because networking benefits firms with market expansion and competitive positioning, but does not enhance their internal operations (Park \& Luo, 2001).

A recent study by Li and Zhang (2007) illustrates that the relationship between firm's political networking and new venture performance grew weaker under strong institutional environment; but the firm's functional experience in sales/marketing, finance, administration, $R \& D$ and manufacturing was positively related to the new venture performance in high-tech industry in emerging market in a low dysfunctional environment characterized by high property rights protection and ability to enforce contracts (Li \& Zhang, 2007) Another study by Li, Zhou, and Shao (2009) shows that the political ties impede 
whereas business ties strengthen the positive relationship between foreign firm's differentiation strategy and profitability in China.

In the changed scenario, SOEs, networks and business groups, among others, are likely to persist (Carney, 2008; Chang, 2006) but are transforming their personalized non-market resources into more transparent and formal ties aimed at transferring to them the technological and managerial knowledge from their multinational partners (Pananond, 2007); or are undergoing restructuring (Hoskisson, Johnson, Tihanyi, \& White, 2005; Kedia, Mukerjee, \& Lahiri, 2006); or creating strategic flexibility (Uhlenbruck, Meyer, \& Hitt, 2003) in order to attain higher performance in the evolving environment. In fact, outward FDI from China, though in its initial stage, is dominated by SOEs (Morck, Yeung, \& Zhao, 2008).

The economic and institutional reforms in emerging markets have provided proper incentives to many other EMFs to bring changes in their corporate culture that has enabled these firms to undertake equity-raising with more corporate disclosures; put in effort to improve industry-specific technological capabilities, build brands, launch more value-added and improved products suitable for the conditions prevalent in emerging markets (Aulakh \& Kotabe, 2008; Hooley, Cox, Shipley, Fahy, Beracs, \& Kolos, 1996; Hoskisson et al., 2000; Newman, 2000; Pananond, 2007), enhance their contracting abilities (Toulan, 2002), and acquire managerial knowledge more appropriate for the changes taking place in the environment (Soulsby \& Clark, 1996).

From the literature review, it can be concluded that emerging markets have a different institutional, economic, societal and resource environments than a developed country. However, EMFs, in general, are making endeavors to develop their resources even under the constrained environment of their home countries. EMFs are no longer depending solely on their non-market resources to tap the evolving opportunities presented to them by the growing home country economies. But the institutional constraints in emerging markets impact the resource-base of EMFs (North, 1990). The literature review in this chapter presents a setting for studying the resource base of EMFs. Hence, in the next chapter, a literature review of Resource-based-view is carried out in order to examine the resource-base of EMFs. 


\section{CHAPTER III}

\section{LITERATURE REVIEW: RESOURCE-BASED VIEW}

The resources of a firm have gained prominent position in IB field. Early IB scholars such as Caves (1971), Dunning (1983), and Hymer (1976) considered resources of a firm as drivers of its FDI. These scholars, though, used a different term, namely ownership-specific advantage, instead of resource. Dunning (1983) distinguishes between two kinds of ownership-specific advantages of a multinational firm, namely asset-specific ownership advantages $\left(\mathrm{O}_{\mathrm{A}}\right)$ and transaction-specific ownership advantages $\left(\mathrm{O}_{\mathrm{T}}\right)$. The model in the dissertation is concerned with EMF's asset-specific ownership advantages, which are similar to the term 'resources' in the resource-based view of firm. A literature review of resource-based view may help us understand and categorize EMFs' resource types, which form an important constituent of the conceptual model presented in the dissertation.

The resource-based view of firm states that a firm's internal resources, and not its external environment, give the firm a sustained competitive advantage in the marketplace. Firm resources include all assets, capabilities, organizational processes, firm attributes, information, knowledge etc. controlled by the firm that enable it to conceive of and implement strategies that improve its efficiency and effectiveness (Barney, 1991). Resources are heterogeneously distributed among different firms and provide competitive advantage to those firms that have a portfolio of valuable, rare, inimitable and non-substitutable resources (Amit \& Schoemaker, 1993; Barney, 1991; Crook, Ketchen, Combs, \& Todd, 2008; Grant, 1991; Peteraf, 1993; Wernerfelt, 1984). These advantage-generating resources cannot be purchased in factor market (Dierickx \& Cool, 1989). Resources such as technological abilities, reputation and brand name, management skills, size, and international experience etc. have long been recognized as one of the key drivers of a firm's internationalization (Caves, 1971; Dunning, 1983; Hymer, 1976; Yeung, 1994) because resources help an entrant firm to overcome disadvantages (Beamish, 1984), knowledge gaps (Petersen, Pedersen, \& Lyles, 2008) and liability of foreignness (Zaheer, 1995; Zaheer \& Mosakowski, 1997) in a host country.

It is highly likely that resource-base of firms from different countries may differ from each other because firms develop unique resources to meet the idiosyncratic requirements of their home countries' 
heterogeneous resource environments (Miller \& Shamsie, 1996; Priem \& Butler, 2001; Wan, 2005) that determine the relative competitive advantages of home country firms (Chan, Isobe, \& Makino, 2008; Fagre \& Wells, 1982). Moreover, the heterogeneity in economic and institutional conditions, that shape the transformational and transactional capabilities of firms (North, 1990), determines whether the local firms would be motivated to invest in path-breaking inventions and develop technological resources. This suggests that the developed country firms may have different resource-base than EMFs because the two sets of countries differ in their country-specific advantages.

The resource, economic and institutional environments in developed countries are such that the local firms invest in path-breaking technologies and develop tangible property-based and intangible knowledge-based resources (Khanna \& Palepu, 1997). Such firms grow big and erect high entry barriers on strength of efficient process and innovative product transformational technologies since firms in the developed country environment are made available cheap finances and skilled labor (Wan, 2005).

On the contrary, EMFs have limited incentive to develop innovative path-breaking technologies or develop superior managerial skills as property rights regime is weaker in emerging markets, restricting the growth of these firms (Peng \& Heath, 1996; Wan, 2005). The unpredictable government policies also stymie the growth of firms (Khanna \& Palepu, 1997). EMFs incur high transaction cost to access resources at home (Chittoor \& Ray, 2007; Xin \& Pearce, 1996). Lack of infrastructure in emerging markets hampers the brand-building efforts of EMFs (Khanna \& Palepu, 1997), which do not possess international brands and are perceived as producers of low-quality goods by consumers in developed countries (Cordell, 1993). Thus, EMFs, in general, do not possess as strong physical, value-generating, or proprietary knowledge resources such as size, experience, proprietary innovative technologies, superior human capital, reputation or world-recognized brands as are possessed by the developed country firms (Barney \& Arikan, 2001;

Craig \& Douglas, 1997; Erramilli, Agarwal, \& Kim, 1997; Sol \& Kogan, 2007).

The distinctions between the resource-base of two sets of firms may be better understood if an attempt is made to categorize the various types of firm resources. The extant literature provides some categorizations of firm's resources. Some of the resource types are given in Table 1: 
Table 1: Resource Types in Extant Literature.

\begin{tabular}{|c|c|c|}
\hline Resource Type & $\begin{array}{c}\text { Author and } \\
\text { Year }\end{array}$ & Explanation of Resource Type \\
\hline $\begin{array}{l}\text { Tangible / intangible } \\
\text { resources }\end{array}$ & $\begin{array}{l}\text { Wernerfelt, } \\
1984\end{array}$ & $\begin{array}{l}\text { Tangible resources: financial and production-related assets } \\
\text { like machine capacity; } \\
\text { Intangible resources: know-how, reputation, networks, } \\
\text { organizational culture, patents and licenses. }\end{array}$ \\
\hline $\begin{array}{l}\text { Human / } \\
\text { organizational / } \\
\text { physical resources }\end{array}$ & Barney, 1991 & $\begin{array}{l}\text { Human resources: training, experience and relationships of } \\
\text { managers and workers inside a firm; } \\
\text { Organizational resources: reporting system, planning, } \\
\text { coordination etc.; } \\
\text { Physical resources: plant \& equipment, geographic location; } \\
\text { physical technology. }\end{array}$ \\
\hline $\begin{array}{l}\text { Physical / financial / } \\
\text { human / technological } \\
\text { / reputation / } \\
\text { organizational } \\
\text { resources }\end{array}$ & Grant, 1991 & $\begin{array}{l}\text { Financial resources: Cash, ability to raise finances; } \\
\text { Technological resources: patents; } \\
\text { Reputation: brand reputation. }\end{array}$ \\
\hline $\begin{array}{l}\text { Contained / system } \\
\text { resources }\end{array}$ & $\begin{array}{l}\text { Black \& } \\
\text { Boal, } 1994\end{array}$ & $\begin{array}{l}\text { Contained resource: an identified simple network of resource } \\
\text { factors that can be monetarily valued and traded; } \\
\text { System resource: socially created, complex network of firm } \\
\text { resource factors which make the monetary valuation and } \\
\text { tradability of a system resource implausible }\end{array}$ \\
\hline $\begin{array}{l}\text { Property-based / } \\
\text { knowledge-based } \\
\text { resources }\end{array}$ & $\begin{array}{l}\text { Miller \& } \\
\text { Shamsie, } \\
1996\end{array}$ & $\begin{array}{l}\text { Property based resource: appropriable, controllable, specific } \\
\text { and well-defined resource which is protected from imitation } \\
\text { by virtue of property rights. Examples are organizational } \\
\text { slack, internally generated profits and externally raised }\end{array}$ \\
\hline
\end{tabular}




\begin{tabular}{|c|c|c|}
\hline & & $\begin{array}{l}\text { finances, patents and licenses. } \\
\text { Knowledge-based resource: protected from imitation by virtue } \\
\text { of knowledge barriers Examples are technological, managerial } \\
\text { and marketing skills. }\end{array}$ \\
\hline $\begin{array}{l}\text { Advantageous / } \\
\text { disadvantageous / } \\
\text { complementary } \\
\text { resources }\end{array}$ & $\begin{array}{l}\text { Curevo- } \\
\text { Cazurra, } \\
\text { Maloney, \& } \\
\text { Manrakhan, } \\
2007\end{array}$ & Disadvantageous resources: core-rigidities \\
\hline $\begin{array}{l}\text { Market / non-market } \\
\text { resources }\end{array}$ & $\begin{array}{l}\text { Hirschman, } \\
\text { 1958; } \\
\text { Kobrin, } 1980\end{array}$ & $\begin{array}{l}\text { Non-market resource: helps a firm regulate its non-market } \\
\text { environment that includes relationship with actors such as } \\
\text { government institutions and community, which provide orders } \\
\text { to markets, firms and other types of institutions and } \\
\text { organizations to repair their failures and function them } \\
\text { effectively and efficiently; but does not include firm's buying } \\
\text { and selling relationships; } \\
\text { Market resource: helps a firm consummate its market-related } \\
\text { tasks such as buying and selling }\end{array}$ \\
\hline $\begin{array}{l}\text { Customer assets / } \\
\text { channel assets / input } \\
\text { assets / process assets } \\
\text { / market knowledge } \\
\text { assets }\end{array}$ & $\begin{array}{l}\text { Verdin \& } \\
\text { Williamson, } \\
\text { 1994; } \\
\text { Markides \& } \\
\text { Williamson, } \\
1996\end{array}$ & $\begin{array}{l}\text { Customer assets: brand recognition, customer loyalty and } \\
\text { installed base. } \\
\text { Channel assets: established channel access, distributor loyalty } \\
\text { and pipeline stock. } \\
\text { Input assets: knowledge of imperfect factor markets, loyalty of } \\
\text { suppliers and financial capacity. } \\
\text { Process assets: proprietary technology, product or market- } \\
\text { specific function experience and organization systems } \\
\text { Market knowledge assets: accumulated information on the }\end{array}$ \\
\hline
\end{tabular}




\begin{tabular}{|l|l|l|}
\hline & $\begin{array}{l}\text { goals and behavior of competitors, price elasticity of demand or } \\
\text { market response to business cycle. }\end{array}$ \\
\hline
\end{tabular}

It can be inferred that the above-tabulated resource types are more suitable for categorizing the resources of developed country firms, though some of the above-mentioned resource typologies can be used to categorize some (but not all) resource-types of EMFs. For example, non-market resources can be used to label the resources of EMFs that network with governments to create asymmetry-based competitive advantages (Hoskisson et al., 2000; Miller, 2003). Similarly, market knowledge assets can describe the resources of EMFs that apply, to internationalize, the knowledge of how business gets done in emerging markets (Sol \& Kogan, 2007). However, there are other resources of EMFs, which solicit a new set of resource typologies, more amenable to describe the resources of EMFs. For example, a survey by UNCTAD (2006) found that the competitive advantages of EMFs stem from relationship management, cultural affinity and organizational structure. Aulakh et al. (2000) suggest that EMFs can excel in commodities since emerging markets possess plentiful natural resources and low cost labor. Mathews (2006) proposes that EMFs develop resources by learning through their linkage with developed country firms and leveraging those resources and linkages to internationalize.

Based on the EMFs' resource description in the literature, this dissertation uses some existing and develops some new resource typologies to propose the following four resource types for EMFs:

- Relational resources,

- Market knowledge resources,

- $\quad$ Process-related resources, and

- Natural asset based resources.

These typologies are in line with the six generic strategies suggested for the internationalization of EMFs (Craig \& Douglas, 1997) namely low-cost commodity, component manufacturing, private label manufacturing, low-cost leader, first generation technology, and specialized niche. A detailed description of each of these resources and how these help in internationalization of EMFs follows. 
1) Relational Resources: A firm's relationship with external constituents has been acknowledged as a resource (Dyer \& Singh 1998). Relational resources generate reciprocity-based trust, information sharing and joint problem-solving among partners (Uzzi, 1997). In fact, FDI by EMFs is proposed as management of important network relations (Chen, 2003). There are following three types of relationships observed in case of EMFs.

- $\quad$ with home and host governments, and with local and foreign financial institutions and banks. This has been termed "Non-market Resource" in the dissertation;

- with ethnic population termed "Ethnic Relational Resource";

- with foreign technology partners in OEM or joint venture relationship termed "Business Relational Resource”.

(i) Non-market Resources: These resources provide the firms with an adaptive ability to move beyond the institutional constraints and play a more active role in constrained environments (Oliver, 1991), and have been found to positively influence the firm performance (Peng \& Luo, 2000), including new venture performance even in high-tech industry under weak institutional regimes of emerging markets (Li \& Zhang, 2007). The firms in emerging markets create sustainable competitive advantage by erecting asymmetry barriers and institutional barriers (Farashahi \& Hafsi, 2009; Miller, 2003; Wan, 2005) through developing non-market resources that provide them access to the scant physical resources and restrict others from accessing the same resources (Boddewyn, 1988; Brewer, 1993; Khanna \& Palepu, 1997; Malik, 2008; Wan, 2005). Non-market resources are drawn from cultivation of network resources by managers of a focal firm by cooperating and exchanging favors with managers of other local firms and governmental authorities (Acquaah \& Bryan, 2007; Hong, 2004; Luo, 2001; Park \& Luo, 2001; Xin \& Pearce, 1996).

Non-market resources of firms engender them an ability to manage institutional idiosyncrasies and help in their internationalization (Henisz, 2003) because different institutional environments in host countries may render a resource incapable of providing the competitive advantage to a multinational (Black \& Boal, 1994; Brouthers, Brouthers, \& Werner, 2008; Oliver, 1997). Multinational firms are finding it hard to harmonize or coordinate the different institutional environments in different countries because their 
objectives may differ from the host country objectives (Makhija, 1993); resulting in increase in crossborder transaction costs whenever these firms locate in institutionally dissimilar environments (Dunning, 2009) and poor performance by foreign affiliates (Delios \& Henisz, 2000).

Though, government's intervention in emerging markets is going down, there are some industries such as infrastructure development where government intervention is still very high (Henisz, 2003) and investment policies for foreign firms have been volatile (Doh \& Ramamurti, 2003). The development of infrastructure is marred with unclear regulations, expropriation hazards (Henisz \& Zelner, 2001), and lack of credible promises by emerging market governments (Doh \& Ramamurti, 2003). Such a scenario offers EMFs a strategic opportunity to invest in infrastructure sector in other emerging markets (Canal-Garcia \& Guillen, 2008; Ghemawat \& Khanna, 1998) because EMFs can utilize their non-market resources to gain an edge in constrained host country environments. The developed country firms have been reluctant to invest in infrastructure sectors in emerging markets (Ramamurti, 2004) since a failure to understand the institutional environment results in unforeseen costs and political hazards in global projects for the firms (Henisz, 2000; Orr \& Scott, 2008). In fact, emerging market infrastructure firms are among the largest foreign investors in infrastructure sectors in other emerging markets, outperforming their developed nation counterparts (Curevo-Cazurra \& Genc, 2008). For example, Chilean firms have been investing in infrastructure sectors in other Latin American countries where economic and institutional liberalization occurred later, and were more successful than their developed country counterparts, since they could apply the liberalization know-how lessons learnt in Chile to other Latin American countries where similar conditions unfolded later (Sol \& Kogan, 2007).

(ii) Ethnic Relational Resources: The other kind of relational resource stems from the ethnic relationships which have played catalytic roles in creating home-grown multinationals in emerging markets (Gillespie, Riddle, Sayre, \& Sturges, 1999; Ramamurti, 2004), because EMFs, in general, have limited knowledge of other international markets (Luo \& Tung, 2007). Ethnic community can help a new entrant understand the local rules of the land and provide access to key government actors (Chen \& Chen, 1998). For example, Thailand's eminent business groups namely Charoen Pokphand and Siam Cement internationalized on strength of their ethnic relationships (Pananond, 2007). Additionally, ethnic 
community residing in a host country can open doors to some key customers in the host country. For example, software industry in India grew partially on strength of diaspora in the USA and Europe (Kapur \& Ramamurti, 2001). Moreover, ethnic community in a host country can itself act as key customers. Jollibee Group of Philippines draws on the ethnic community to open its restaurants internationally. Similarly, Televisa from Mexico has launched its international operations by developing products that cater to the taste of people with common ethnicity.

(iii) Business Relational Resources: Another type of relational resource arises from business

relationships of local EMFs either under OEM or contract supplier relationships with the developed country firms that set up local operations with market-seeking strategy and are either forced by the host country governments to use local components (Luo, 2002) or voluntarily seek such relationships to enhance their competitiveness (Swamidass \& Kotabe, 1992). Consequently, OEM relationships develop between the local EMF and the developed country multinationals (Luo \& Tung, 2007). Some other firms undertake contract manufacturing for supplying goods to the developed country multinationals under private labels (Dawar \& Frost, 1999). Such contract-based operations have given an opportunity to these EMFs to learn from their foreign partners and have led to, over a period of time, their expertise-development in management and mass production with product-quality at par with the standards expected by multinational firms (Lall, 1983; Li, Lin \& Arya, 2008; Luo \& Tung, 2007; Meyer, 2004). These local firms then use their relationships to gain foothold in other markets (Elango \& Pattanaik, 2007; Luo \& Tung, 2007; Yiu et al., 2007) by using their partners' complementary skills (Elango \& Pattanaik, 2007; Khanna \& Palepu, 1997, 2000; Khanna \& Yafeh, 2005; Pananond, 2001; Peng, 2003; Peng \& Zhao, 2005; Yeung, 2000). For example, Haier, a multinational EMF from China started as a private-label supplier to Liebherr of Germany (Liu \& Li, 2002), and later stepped up its international efforts by launching its own brand. Vertical relational ties resulted in increased manufacturing productivity for Argentinean furniture firms and helped them access global markets (Mesquita \& Lazzarini, 2008). Many other EMFs get an opportunity to expand abroad as sub-contractor to an existing multinational or local global customer when the latter launch their operations into a new international market (Mathews, 2006). For example, multinational banks from emerging markets are likely to follow their clients while internationalizing (Petrou, 2007). 
have adopted flexibility in their strategies and carried out dynamic alteration in their resources (Uhlenbruck et. al, 2003) to develop suitable products for local consumers who are less-demanding but have distinct, though infrequent changes, in customer tastes (Aulakh et al., 2000; Dawar \& Frost, 1999; Luo, 2001), requiring EMFs to not introduce as many innovative products in emerging markets as are required by the developed country firms in their home markets (Aulakh et al., 2000). Further, EMFs have acquired marketing skills to match the infrastructure challenges and rudimentary distribution channels present in their countries (Aulakh et al., 2000; Dawar \& Frost, 1999; Gomez, 1997; Lall, 1983; Sol \& Kogan, 2007).

Equipped with this knowledge of their local markets, EMFs are able to project how operations are conducted in other emerging markets and the least developed countries (Lall, 1984) and hence, face lower knowledge gap when they internationalize in markets with similar economic, institutional and resource environments (Lee \& Beamish, 1995). EMFs turn the disadvantage of operating in a turbulent institutional and economic environment replete with poorer regulatory quality, lower control over corruption, underdeveloped infrastructure, and less-innovative products into an advantage when they invest in other emerging markets and the least developed countries where institutional and economic environments are similar (Cazzura \& Genc, 2008; Dawar \& Frost, 1999; Lecraw, 1993; Luo \& Tung, 2007; Sol \& Kogan, 2007). For example, business and commercial practices in countries such as China (for example: unique terms of payment, higher price sensitivity, and personnel direct marketing) are different from those in developed countries (Luo, 2001) and may give Chinese firms an advantage in other emerging markets.

Developed country firms, on the contrary, cannot work successfully with their traditional strategies to tap the low-income strata in emerging markets (London \& Hart, 2004; Ricart et al., 2004) as business culture specificity impedes exploitation of existing capabilities which are rendered irrelevant and redundant under different external environments of emerging markets (Dunning, 1995; Itaki, 1991; Luo, 2002; Miller \& Shamsie, 1996; Priem \& Butler, 2001; Wan, 2005). Consequently, Korean firms reported higher stability of and satisfaction with their joint ventures' performance than did the developed country firms (Lee \& Beamish, 1995). Telecommunication firms from the USA avoided markets with high uncertainty in resource environment (Dowell \& Killaly, 2008). 
environment in some industries. The motivating business environment in these industries accrues from either the government's investment in education that has created skilled labor-force at affordable rates in these emerging markets; or creation of a suitable policy environment and infrastructure that have attracted developed country multinational firms in secondary industrial sectors to turn these emerging markets into manufacturing base with efficiency-seeking FDI. Multinationals have begun to produce standardized intermediary goods in these emerging markets (Dunning, 1988; Makino, Beamish, \& Zhao, 2004; Meyer, 1998; Uhlenbruck \& Castro, 2000; Vernon, 1966). At the same time, the governments have provided financial supports to the incumbent firms to become internationally competitive (Buckley et al., 2007; Wan, 2005).

Some of the progressive local firms have capitalized on the availability of skilled but cheap laborforce in their home country by developing low-cost process technological alternatives to mature, laborintensive and standardized technologies from the developed countries (Meyer, 2004).

The initial resources of these EMFs have been further augmented through the technological, international market access, and managerial knowledge spillovers from local presence of developed country multinationals in their industries (Banga, 2006; Buckley, Clegg, \& Wang, 2002; Chang \& Xu, 2008; Meyer, 2004; Tian, 2007; Wei \& Liu, 2006). Besides spillovers, productivity gains for the progressive domestic firms have also been observed from the location of foreign firms in emerging markets (Aitken \& Harrison, 1999; Chang \& Xu, 2008; Meyer, 2004). The productivity gains have the potential to enhance the international competitiveness (Porter, 1990) of EMFs in their industries. For example, several multilatinas became multinationals when their countries undertook structural reforms (Cazzura, 2008).

As a result, some EMFs have become internationally competitive in standardized, massproduction based process technologies by offering low-cost solutions (Dawar \& Frost, 1999; Kumar \& McLeod, 1981; Lecraw, 1983; Wells, 1983). Thus, EMFs have become internationally competitive in contract manufacturing, building materials, software-coding, and breweries; despite their smaller sizes, distance from key consumer markets and lack of resources (Klein \& Wocke, 2007; Mathews, 2006). 
Many of these EMFs are observed to augment their resources by investing in developed countries (Chen \& Chen, 1998; Child \& Rodrigues, 2005; Chittoor et al., 2009; Lecraw, 1993; Lee \& Slater, 2007;

Luo \& Tung, 2007; Klein \& Wocke, 2007; Makino et al., 2002; Mathews, 2006) and are able to outgrow the investment development path of their countries (Narula \& Dunning, 2000) with an aim to excel in development of product based technologies, besides process-based technologies. But the product-based technological breakthroughs by them are more likely to be incremental and competence-enhancing than the competence-destroying type (Tushman \& Anderson, 1986).

Natural Asset based Resource: Some emerging markets are endowed with plentiful natural resources. Some firms in these nations can either compete worldwide in those natural commodities or transform those natural resources into some value-added products at relatively cheaper rates because of availability of low-cost labor (Aulakh et al., 2000; Dawar \& Frost, 1999), as a nation can be competitive worldwide in those goods that utilize in their production process the abundant factors of that country (Makino et al., 2004).

EMFs have gained foothold in natural commodities and natural resource based value-added products (Aulakh et al., 2000). Examples include Mittal Steel, Tata Steel and Indonesian pulp and paper manufacturing firms (Kedia et al., 2006; Luo \& Tung, 2007; Mathews, 2006).

It can be concluded from the literature review in this chapter that the resource base of EMFs is different from those of developed country firms, though many resources of EMFs are derived from their relationships with or presence of developed country firms in emerging markets. The difference in resource base can be attributed to the differences in institutional and resource environments between developed countries and emerging markets. It can further be understood that despite possessing a resource base which is different from the resources that have been considered as drivers of multinationality of firms, EMFs can still internationalize with help of their resource portfolios. As the dissertation draws data from the survey of Indian software firms which have internationalized based on their process-related resources, it examines the impact of process-related resources on the location choice of these firms.

Resources endow a firm with sustained competitive advantage when these resources are used to craft value-creating strategies (Armstrong \& Shimizu, 2007; Barney \& Arikan, 2001; Hitt, Bierman, 
Shimizu, \& Kochhar, 2001; Newbert, 2007) that are matched with the external environment (Miller \& Shamsie, 1996) and are not simultaneously being implemented by current or potential competitors (Barney, 1991). Thus, it is the interaction of firm's resources and its strategies that produce positive firm performance (Hitt et al., 2001).

Since strategies are crafted in an environment of high uncertainty and complexity by managers who have bounded-rationality (Gavetti \& Rivkin, 2007) and discretion in resource deployment and development (Amit \& Schoemaker, 1993), the conditions of firm heterogeneity in possession and usage of resources will result in different strategies by different firms. For example, various resource types give rise to different alliance strategies for firms (Eisenhardt \& Schoonhoven, 1996; Hoffmann, 2007; Park, Chen, \& Gallagher, 2002; Villalonga \& McGahan 2005); different firm diversification strategies (Chatterjee \& Wernerfelt, 1991); different strategic paths (Teece, Pisano, \& Shuen, 1997); vertical integration decisions (Argyres, 1996); early or late entry (Schoenecker \& Cooper, 1998); entry mode choice (Anand \& Delios, 2002); outsourcing decision (Almor \& Hashai, 2004; Jacobides \& Hitt 2005); and different product launch strategies (Hsieh, Tsai, \& Hultink, 2006). Thus, different resource types are likely to generate different types of strategies.

In the next chapter, I review the literature on firms' internationalization strategy or motive. By internationalization strategy, the dissertation means the motivations of firms for going abroad (Dunning, 1983). The term internationalization strategy, herein, does not purport to mean the multinational's control and structure related strategies, namely multidomestic, international, global and transnational strategies as proposed by Bartlett and Ghoshal (1989). 


\section{CHAPTER IV}

\section{LITERATURE REVIEW: INTERNATIONALIZATION STRATEGIES}

Internationalization strategies of a firm may affect its host country location choices because a firm may not be able to implement all of its potential strategies in a host country, given the institutional, resource, economic, and societal make-up of the host country. A literature review of internationalization strategy may help us understand the strategy types a firm may have for its international market and at the same time, it may help us select the internationalization strategies that can form part of our model and be further examined.

Extant literature has identified many generic strategies of firms proposed by scholars such as Hambrick (1983), Miles and Snow (1978), and Porter (1980) among others. In the context of international business, scholars such as Cantwell (1989) and Dunning (1980) stand out for proposing strategies adopted by multinational firms.

Miles and Snow (1978) used the firms' strategies to categorize the former as defenders, prospectors, analyzers and reactors. Defender firms prosper through stability, reliability and efficiency; Prospector firms prosper through stimulating and meeting new product-market opportunities; Analyzer firms prosper by being more innovative than defenders but less innovative than prospectors; Reactors keep vacillating in their environment and fail to prosper (Miles \& Snow, 1978). The strategies suggested by Miles and Snow (1978) have been used by a limited set of studies in IB. Analyzer orientation is demonstrated to be the best suited for Chinese markets, while prospector and defender strategies result in poor financial performance for market-seeking subsidiaries of foreign firms (Luo \& Park, 2001).

Porter (1980) proposed cost-based and differentiation-based strategies. Another dimension on which generic strategy of a firm can be described is its focused or broad market scope (Porter, 1980). The performance impact of generic strategies was shown to be contingent upon the environmental factors with cost strategy working better in stable markets, while differentiation strategy working better in volatile environment (Miller, 1988). These generic strategies have been studied in context of EMFs by Aulakh et al. (2000) wherein they researched the relationship between the generic strategies of, choice of host country location by, and performance of Latin American firms. They found that the cost-based strategies in 
developed countries while the differentiation-based strategies in developing countries were associated with better performance for Latin American firms. Li et al. (2009) demonstrate that low cost or differentiationbased strategies are associated with foreign firms' profitability in China. A recent meta-analysis showed that the cost and differentiation paradigm of competitive strategy should be enhanced since its linkage with the performance has not been established (Campbell-Hunt, 2000).

Hambrick (1983) suggested that firms can follow four generic strategy types, namely cost efficiency, asset parsimony, differentiation, and scale/scope. Firms following cost efficiency strive to lower the cost incurred per unit of output; whereas firms following asset parsimony strive to use fewer resources per unit of output. Differentiation and scale/scope strategy types are the same as defined by Porter (1980). The strategy types proposed by Hambrick for mature industries have been used by few scholars in IB. Specifically keeping a multinational firm in view, Dunning (1983) proposed typologies for the international strategies (he calls them motives though) of multinational firms. These motives are marketseeking, resource-seeking, efficiency-seeking and/or asset-seeking (Dunning, 1983) with chief aim of all these motives being to increase the firm's competitiveness. Resource-seeking firms invest abroad to gain access to (i) cheaper physical natural raw materials such as minerals, agriculture, or (ii) cheaper unskilled or semi-skilled labor, or (iii) technological or management or marketing expertise. Market-seeking firms invest abroad to gain access to the customers and markets in host country. Efficiency-seeking firms invest abroad to make optimum use of location-specific advantages with an aim to achieve efficiency through economies of scale and scope. Asset-seeking firms invest abroad to gain access to the assets of foreign firms. Dunning's four typologies have been extensively used in research works in context of emerging markets, as shown in the following paragraph.

Developed country firms have entered emerging markets with market-seeking or efficiencyseeking motives as standardized intermediate products can now be sourced from wherever it is cheapest to produce these products (Dunning, 1980; Narula \& Dunning, 2000; Makino et al., 2004; Porter, 2000; Sethi et al., 2003; Uhlenbruck \& Castro, 2000). FDI by developed country firms driven by efficiency-seeking motives has been more successful than market-seeking motives in emerging markets (Meyer, 1998). Curevo-Cazurra (2007) suggested that EMFs from Latin America went international to set up production, 
marketing subsidiaries or a combination of the two. EMFs that have location specific advantages in home country are more likely to start with marketing subsidiaries first. EMFs that have location-specific advantages in host country (like natural resources or acquisition target) are more likely to start with production subsidiaries and also those firms that can easily transfer their products and technologies abroad are more likely to go for production subsidiaries first (Cazzura, 2007). Though EMFs have been internationalizing with these four motives or strategies (Deng, 2003), asset-seeking motive and marketseeking motive have been widely accepted for EMFs (Mathews, 2006; Luo \& Tung, 2007; Peng \& Wang, 2000). Firms from emerging markets are securing valuable organizational resources in international markets to enhance competitiveness (Cantwell, 1989; Child \& Rodrigues, 2005; Hoskisson et al., 2005; Lee \& Slater, 2007; Luo \& Tung, 2007; Mathews, 2006; Narula \& Dunning, 2000).

Dunning, later added three other motives for multinationals' activities. These motives are escape investments, support investments, and passive investments (Dunning \& Lundan, 2008). Escape investments refer to the FDI made to escape restrictive legislation or macro-organizational policies by home governments. Examples include round-tripping of investments between China and Hong-Kong (Dunning \& Lundan, 2008). Support investments are FDIs acting as cost-centers with an aim to support the activities of rest of the firm. Examples include purchasing outfits of companies like Sears and Wal-Mart (Dunning \& Lundan, 2008). Passive investments are portfolio investments with equity infusion but no direct management control. Examples are petro-dollar investments by Middle-Eastern firms (Dunning \& Lundan, 2008). As these three motives are not the mainstream motives of multinational firms, these three motives have found limited use in IB research.

Cantwell (1989) suggested that a multinational firm can go abroad either with asset-exploitation or asset-augmentation strategies. Asset-exploitation is transfer of firm's proprietary assets abroad and assetaugmentation is acquisition of strategic assets such as marketing, technological or management skills by firm. Cantwell's strategies have also been used in context of emerging markets, but their emphasis is more on technological acquisition, as shown in the following references. The technically advanced firms are increasingly dispersing their activities geographically in order to augment their technical assets (Cantwell, Dunning \& Janney, 2004; Cantwell \& Janney, 1999, Kummerle, 1996). EMFs internationalize to gain 
managerial and technical knowledge (Aulakh, 2007; Lecraw, 1993). EMFs may start internationalization with asset-exploitation mode, but soon follow it with asset-augmentation mode (Klein \& Wocke, 2007). Multinational's asset exploitation and asset building are inversely associated with environmental complexity and industrial uncertainty (Luo, 2002). Business culture specificity impedes exploitation but not capability building (Luo, 2002). For example, the success of firms like Haier, Lenovo and South African Breweries in developed countries like the USA supports their operations in other countries through technological and reputational spin-offs (Liu, 2007; Liu \& Li, 2002; Klein \& Wocke, 2007).

Hitt, Hoskisson, and Kim (1997) suggest that firms diversify internationally with various motives such as economies of scale, access to new resources, location advantages, cost reduction, and knowledge acquisition. Nachum and Zaheer (2005) proposed that multinational firms have market-seeking, efficiencyseeking, resource-seeking, export-seeking and knowledge-seeking motives to go international.

Specific to internationalization of EMFs, Craig and Douglas (1997) proposed six generic strategies, namely low-cost commodity, component manufacturing, private label manufacturing, low-cost leader, first generation technology, and specialized niche.

Further, Dawar and Frost (1999) proposed typologies for the international strategies of EMFs. They suggested that EMFs may be defender, dodger, extender and/or contender based on a twodimensional matrix with dimensions as "pressures to globalize in its industry" and 'extent to which it can transfer its resources abroad'. An extender firm can go to analogous markets with similar economic, institutional and/or societal environments; a contender firm can go to any market; a dodger firm is able to gain competitive advantage in its domestic market against the international rivals due to possession of some assets that find value in unique domestic economic, institutional or social environment; and a defender firm has to concentrate on defending its domestic market share against the onslaught of international rivals (Dawar \& Frost, 1990). On the contrary, Luo and Tan (1998) suggest defensive strategies for local firms but analyzer strategies for foreign firms in China.

Luo and Tung (2007) propose that EMFs internationalize for strategic-asset seeking, opportunityseeking and market-seeking purposes. Opportunity-seeking is another perspective added to the existing literature by these scholars. Emerging market and emerging transition market firms face institutional voids 
and trade constraints at home such as quota restrictions and/or anti-dumping penalties, and firms from these countries internationalize to circumvent the constraints at home by seizing opportunities offered by other countries. For example, China's FDI, at its infant stage though, is biased towards tax havens and proximate Southeast Asian countries (Morck et al., 2008).

For the purpose of this dissertation, I propose to use the four typologies proposed by Dunning (1983) and augment them with opportunity-seeking motive proposed by Luo and Tung (2007). The four typologies offered by Dunning (1983) supplemented by Luo and Tung's (2007) opportunity-seeking strategy offer a richer explanation than other existing typologies of internationalization strategies because the former provides a comprehensive coverage of potential strategies that can be followed by EMFs in their internationalization effort. Dunning's (1983) typologies capture parsimoniously the international strategies of multinational firms put forth by various scholars in IB field. It is further believed that these five typologies, namely market-seeking, asset-seeking, efficiency-seeking, resource-seeking, and opportunityseeking would help to understand better the research question in the dissertation. As the empirical examination in the dissertation draws data from Indian software firms, the dissertation focuses on marketseeking and labor-seeking strategies because these two strategies have been used by Indian software firms in international markets.

Firms' strategies affect the internationalization paths of multinationals (Makino et al., 2002). A firm evaluates all possible FDI locations based on traditional determinants and selects the country that best fits its strategy (Sethi et al, 2003). In next chapter, a review of the literature on determinants of host country location choice is carried out. 


\section{CHAPTER V}

\section{LITERATURE REVIEW: DETERMINANTS OF HOST COUNTRY LOCATION CHOICE}

A literature review of determinants of host country location choice is required to study the model proposed in the dissertation. The review will provide a better understanding of the determinants that have been examined by the scholars and will make the model comprehensive enough to consider all determinants already examined by the scholars.

FDI determinants are now complex and multi-dimensional (Sethi et al., 2003) but very important variables as they impact a firm's profitability (Vermeulen \& Barkema, 2003). There have been umpteen research studies to understand the determinants of host country location choice. These studies have been conducted using longitudinal data gathered from firms from different industries including manufacturing (Yu \& Ito, 1988; Rose \& Ito, 2008) and services (Kundu \& Contractor, 1999), different countries (but mainly developed countries), and different time frames to increase the external validity of the research outcomes. Some of these studies have investigated the determinants affecting FDI from a specific home country into several host countries or inward FDI into a specific host country from several home countries, whereas others have used datasets that includes multiple home and host countries. A tabular synopsis of some of the research studies on this topic follows in Table 2.

Table 2: Research on Location Determinants

\begin{tabular}{|l|l|l|l|l|}
\hline Authors & Year & Sample \\
Published & Countries & Industry & Factors affecting FDI \\
examined & location decisions \\
\hline Johanson \& & 1975 & Sweden & & $\begin{array}{l}\text {-ve effect of psychic } \\
\text { distance i.e. firms locate in } \\
\text { proximate countries in initial }\end{array}$ \\
& 1976 & $\begin{array}{l}\text { European and } \\
\text { Canadian firms }\end{array}$ & & years. \\
\hline Flowers & investment in & & +ve effect of oligopolistic \\
& & USA & & \\
\hline
\end{tabular}




\begin{tabular}{|c|c|c|c|c|}
\hline Johanson \& Vahlne & 1977 & Sweden & & $\begin{array}{l}\text {-ve effect of psychic } \\
\text { distance }\end{array}$ \\
\hline Root \& Ahmed & 1978 & $\begin{array}{l}\text { Inward FDI in } \\
\text { developing } \\
\text { countries }\end{array}$ & & $\begin{array}{l}\text { +ve effect of per capita } \\
\text { GNP, low corporate tax and } \\
\text { political stability. }\end{array}$ \\
\hline Nigh & 1986 & USA & Banking & \\
\hline Engwall \& Wallenstal & 1988 & Sweden & Banking & \\
\hline Terpestra \& Yu & 1988 & USA & $\begin{array}{l}\text { Advertising } \\
\text { agencies }\end{array}$ & $\begin{array}{l}\text { +ve effect of customer } \\
\text { presence, oligopolistic } \\
\text { reactions, market size, } \\
\text { international experience, } \\
\text { geographic proximity. }\end{array}$ \\
\hline Yu \& Ito & 1988 & $\begin{array}{l}\text { Inward FDI in } \\
\text { the USA }\end{array}$ & $\begin{array}{l}\text { Tire and textile } \\
\text { industries }\end{array}$ & $\begin{array}{l}\text { +ve effect of oligopolistic } \\
\text { reaction }\end{array}$ \\
\hline Dixit & 1989 & & & $\begin{array}{l}\text {-ve effect of exchange rate } \\
\text { on FDI location }\end{array}$ \\
\hline Benito \& Gripsrud & 1992 & Norway & Manufacturing & $\begin{array}{l}\text { No effect of cultural distance } \\
\text { on location }\end{array}$ \\
\hline Erramilli & 1992 & USA & Services & $\begin{array}{l}\text { Moderating impact of } \\
\text { international experience on } \\
\text { cultural distance and FDI } \\
\text { location }\end{array}$ \\
\hline Li \& Guisinger & 1992 & $\begin{array}{l}\text { USA, Europe, } \\
\text { Japan }\end{array}$ & Services & $\begin{array}{l}+ \text { ve effect of market size and } \\
\text { oligopolisitc reaction, but - } \\
\text { ve effect of cultural distance. }\end{array}$ \\
\hline Woodward \& Rolfe & 1993 & & $\begin{array}{l}\text { Export- } \\
\text { oriented units }\end{array}$ & $\begin{array}{l}\text { +ve effect of per capita } \\
\text { GDP, exchange rates, length }\end{array}$ \\
\hline
\end{tabular}




\begin{tabular}{|c|c|c|c|c|}
\hline & & & & $\begin{array}{l}\text { of income tax holidays, } \\
\text { presence of export- } \\
\text { processing zones, political } \\
\text { stability and manufacturing } \\
\text { concentration; -ve effect of } \\
\text { wage rates, transportation } \\
\text { cost and inflation rates. }\end{array}$ \\
\hline Kumar & 1994 & USA & Export-units & $\begin{array}{l}+v e \text { effect of infrastructure, } \\
\text { size of export-processing } \\
\text { zones, availability of skilled } \\
\text { manpower, while -ve effect } \\
\text { of wage rates, openness of } \\
\text { country }\end{array}$ \\
\hline Hennart \& Park & 1994 & $\begin{array}{l}\text { Japanese } \\
\text { investment in } \\
\text { the USA }\end{array}$ & & $\begin{array}{l}\text { Mimetic effect on location } \\
\text { decision }\end{array}$ \\
\hline Mariotti \& Piscitello & 1995 & $\begin{array}{l}\text { Inward FDI in } \\
\text { Italy }\end{array}$ & & $\begin{array}{l}\text {-ve effect of information } \\
\text { cost assymertry between } \\
\text { foreign and local firms on } \\
\text { foreign firm's location } \\
\text { decisions }\end{array}$ \\
\hline $\begin{array}{l}\text { Huchzermeier \& } \\
\text { Cohen }\end{array}$ & 1996 & & & $\begin{array}{l}\text {-ve effect of corporate tax } \\
\text { and exchange rate on } \\
\text { location decisions }\end{array}$ \\
\hline Kogut \& Chang & 1996 & $\begin{array}{l}\text { Inward FDI in } \\
\text { the USA }\end{array}$ & $\begin{array}{l}\text { Electronics } \\
\text { industry }\end{array}$ & $\begin{array}{l}+ \text { ve effect of prior entry in } \\
\text { and -ve effect of real } \\
\text { exchange rate movements of }\end{array}$ \\
\hline
\end{tabular}




\begin{tabular}{|c|c|c|c|c|}
\hline & & & & the host country \\
\hline Grosse \& Trevino & 1996 & & & $\begin{array}{l}\text {-ve relationship between } \\
\text { cultural, geographic distance } \\
\text { and imports from the USA. }\end{array}$ \\
\hline O’Grady \& Lane & 1996 & Canada & Retailing & $\begin{array}{l}\text { Psychic proximity does not } \\
\text { guarantee success in host } \\
\text { country. Out of } 32 \text { firms } \\
\text { investigated, only } 7 \text { were } \\
\text { successfully functioning in } \\
\text { the USA. }\end{array}$ \\
\hline $\begin{array}{l}\text { Shaver, Mitchell \& } \\
\text { Yeung }\end{array}$ & 1997 & & Manufacturing & $\begin{array}{l}\text { +ve effect of experience in } \\
\text { host country on FDI survival }\end{array}$ \\
\hline Mudambi & 1998 & & & $\begin{array}{l}\text { +ve impact of prior host } \\
\text { country investment on future } \\
\text { investment. }\end{array}$ \\
\hline Yamori & 1998 & Japan & $\begin{array}{l}\text { Financial } \\
\text { institution }\end{array}$ & $\begin{array}{l}\text { +ve effect of manufacturing } \\
\text { FDI and market size. }\end{array}$ \\
\hline Dow & 2000 & Australia & Exporters & $\begin{array}{l}\text { Geographic distance but not } \\
\text { Psychic distance is } \\
\text { significant predictor }\end{array}$ \\
\hline Nachum & 2000 & $\begin{array}{l}\text { Inward FDI in } \\
\text { the USA }\end{array}$ & $\begin{array}{l}\text { Financial } \\
\text { Services }\end{array}$ & $\begin{array}{l}+v e \text { effect of agglomeration } \\
\text { benefits }\end{array}$ \\
\hline Shaver \& Flyer & 2000 & $\begin{array}{l}\text { Inward FDI in } \\
\text { the USA }\end{array}$ & & $\begin{array}{l}+v e \text { effect of agglomeration } \\
\text { on laggards than on leaders }\end{array}$ \\
\hline $\begin{array}{l}\text { Carpenter \& } \\
\text { Fredrickson }\end{array}$ & 2001 & USA & & $\begin{array}{l}+v e \text { effect of TMT's } \\
\text { international experience, } \\
\text { educational and tenure }\end{array}$ \\
\hline
\end{tabular}




\begin{tabular}{|c|c|c|c|c|}
\hline & & & & $\begin{array}{l}\text { heterogeneity on global } \\
\text { strategic posture. }\end{array}$ \\
\hline Henisz \& Delios & 2001 & Japan & MNEs & $\begin{array}{l}\text {-ve effect of political } \\
\text { hazards of host countries. }\end{array}$ \\
\hline Ito \& Rose & 2002 & & Tire & $\begin{array}{l}+\mathrm{ve} \text { effect of oligopolistic } \\
\text { reaction and international } \\
\text { experience. }\end{array}$ \\
\hline Song & 2002 & Japan & MNEs & $\begin{array}{l}\text { Moderating effect of } \\
\text { subsidiary capabilities on - } \\
\text { ve effect of wages. }\end{array}$ \\
\hline Stare & 2002 & $\begin{array}{l}\text { Slovenia, } \\
\text { Czech } \\
\text { Republic, } \\
\text { Hungary }\end{array}$ & Services & $\begin{array}{l}\text {-ve impact of institutional } \\
\text { and cultural distance. }\end{array}$ \\
\hline Zhao, Delios, Yang & 2002 & $\begin{array}{l}\text { Japanese } \\
\text { investment in } \\
\text { China }\end{array}$ & & $\begin{array}{l}\text { +ve effect of regional } \\
\text { development, transportation } \\
\text { infrastructure, market size } \\
\text { and trade }\end{array}$ \\
\hline Zhao \& Zhu & 2000 & $\begin{array}{l}\text { Inward FDI in } \\
\text { China }\end{array}$ & & $\begin{array}{l}\text { +ve effect of market } \\
\text { potential, cost factors and } \\
\text { infrastructure adequacy. }\end{array}$ \\
\hline $\begin{array}{l}\text { Sethi, Guisigner, } \\
\text { Phelan, Berg }\end{array}$ & 2003 & $\begin{array}{l}\text { USA } \\
\text { investment in } \\
\text { East Asia }\end{array}$ & & $\begin{array}{l}\text { +ve effect of low wages and } \\
\text { market size. }\end{array}$ \\
\hline Globerman \& Shapiro & 2003 & USA & MNEs & $\begin{array}{l}\text { +ve impact of governance } \\
\text { infrastructure including } \\
\text { regulation, property rights, }\end{array}$ \\
\hline
\end{tabular}




\begin{tabular}{|c|c|c|c|c|}
\hline & & & & legal systems. \\
\hline $\begin{array}{l}\text { MacCarthy \& } \\
\text { Atthirawong }\end{array}$ & 2003 & & & $\begin{array}{l}\text { Labor costs, political } \\
\text { stability, infrastructure, } \\
\text { economic factors affect } \\
\text { international plant location } \\
\text { decisions }\end{array}$ \\
\hline Henisz \& Macher & 2004 & & Semiconductor & $\begin{array}{l}\text { +ve impact of technological } \\
\text { sophistication of host } \\
\text { country, but-ve impact of } \\
\text { political hazard. }\end{array}$ \\
\hline Trevino \& Mixon & 2004 & $\begin{array}{l}\text { Inward FDI in } \\
\text { Latin America }\end{array}$ & & $\begin{array}{l}\text {-ve effect of institutional } \\
\text { distance }\end{array}$ \\
\hline Bianchi \& Ostale & 2005 & $\begin{array}{l}\text { Inward FDI in } \\
\text { Chile }\end{array}$ & Retailers & $\begin{array}{l}+v e \text { effect of institutional } \\
\text { embeddedness. }\end{array}$ \\
\hline Chang \& Park & 2005 & $\begin{array}{l}\text { Korean firms } \\
\text { investment in } \\
\text { China }\end{array}$ & & $\begin{array}{l}\text { Inverted U-shaped } \\
\text { relationship between } \\
\text { network externalities and } \\
\text { collocation }\end{array}$ \\
\hline $\begin{array}{l}\text { Gimeno, Hoskisson, } \\
\text { Beal, \& Wan }\end{array}$ & 2005 & USA & Telecom & $\begin{array}{l}\text { Mimetic effect on location } \\
\text { decision }\end{array}$ \\
\hline Kim & 2005 & $\begin{array}{l}\text { USA } \\
\end{array}$ & Auto-parts & $\begin{array}{l}\text { Geographic proximity to } \\
\text { customers is preferred to re- } \\
\text { location to Mexico where } \\
\text { wages are low. }\end{array}$ \\
\hline $\begin{array}{l}\text { Tihanyi, Griffith \& } \\
\text { Russell }\end{array}$ & 2005 & Meta-analysis & & $\begin{array}{l}\text { No significant relationship } \\
\text { between cultural distance } \\
\text { and international }\end{array}$ \\
\hline
\end{tabular}




\begin{tabular}{|c|c|c|c|c|}
\hline & & & & $\begin{array}{l}\text { diversification, but -ve } \\
\text { effect for high-tech } \\
\text { industries. }\end{array}$ \\
\hline Alcacer & 2006 & & $\begin{array}{l}\text { Cellular } \\
\text { handset }\end{array}$ & $\begin{array}{l}\text { +ve agglomeration effects } \\
\text { on R\&D subsidiary and for } \\
\text { less capable firms }\end{array}$ \\
\hline $\begin{array}{l}\text { Rothaermel, Kotha, \& } \\
\text { Steensma }\end{array}$ & 2006 & $\begin{array}{l}\text { Outward FDI } \\
\text { from USA }\end{array}$ & Internet firms & $\begin{array}{l}\text {-ve relationship with country } \\
\text { risk, cultural distance, } \\
\text { uncertainty avoidance; +ve } \\
\text { relationship with } \\
\text { individualism and } \\
\text { masculinity. Market size } \\
\text { moderated the relationship. }\end{array}$ \\
\hline Alcacer \& Chung & 2007 & $\begin{array}{l}\text { Inward FDI in } \\
\text { the USA }\end{array}$ & & $\begin{array}{l}\text { +ve effect of industrial } \\
\text { agglomeration on less } \\
\text { capable firms; while +ve } \\
\text { effect of academic } \\
\text { agglomeration on more } \\
\text { capable firms. }\end{array}$ \\
\hline $\begin{array}{l}\text { Bhardwaj, Dietz \& } \\
\text { Beamish }\end{array}$ & 2007 & 43 nations & & $\begin{array}{l}\text { Cultural dimensions, namely } \\
\text { uncertainty avoidance has - } \\
\text { ve effect, but trust has } \\
\text { moderating effect on FDI }\end{array}$ \\
\hline $\begin{array}{l}\text { Filatotchev, Strange, } \\
\text { Piesse, \& Lien, }\end{array}$ & 2007 & $\begin{array}{l}\text { Taiwanese } \\
\text { firms } \\
\text { investment in } \\
\text { China }\end{array}$ & & $\begin{array}{l}\text { Ownership structure of firms } \\
\text { has influence on location } \\
\text { decision. }\end{array}$ \\
\hline
\end{tabular}




\begin{tabular}{|c|c|c|c|c|}
\hline Flores \& Aguilera & 2007 & $\begin{array}{l}\text { Top } 100 \text { US } \\
\text { MNCs }\end{array}$ & & $\begin{array}{l}\text { +ve effect of market } \\
\text { affluence, infrastructure, } \\
\text { similarity in political and } \\
\text { legal systems, trust levels; } \\
\text { but-ve effect of cultural } \\
\text { distance and wage levels. }\end{array}$ \\
\hline $\begin{array}{l}\text { Hutzschenreuter, } \\
\text { Pedersen, \& Volberda }\end{array}$ & 2007 & & & $\begin{array}{l}\text { +ve impact of managerial } \\
\text { intentionality and firm } \\
\text { experience; while } \\
\text { moderating impact of } \\
\text { institutional forces on } \\
\text { internationalization path. }\end{array}$ \\
\hline Petrou & 2007 & & Banks & $\begin{array}{l}\text { +ve effect of customer } \\
\text { presence on developing } \\
\text { country banks' location } \\
\text { decisions; while +ve effect } \\
\text { of market size on developed } \\
\text { country banks' decisions. }\end{array}$ \\
\hline Pusterla \& Resmini & 2007 & $\begin{array}{l}\text { Inward FDI in } \\
\text { Hungary, } \\
\text { Bulgaria, } \\
\text { Romania, } \\
\text { Poland }\end{array}$ & & $\begin{array}{l}\text { +ve effect of market size and } \\
\text { agglomeration; while -ve } \\
\text { effect of per capita wages. }\end{array}$ \\
\hline Tsang \& Yip & 2007 & Singapore & MNEs & $\begin{array}{l}\text { +ve impact of economic } \\
\text { distance on FDI hazard rates }\end{array}$ \\
\hline Cuervo-Cazurra & 2008 & Latin America & MNEs & $\begin{array}{l}\text { Initially expanded to } \\
\text { economically closer }\end{array}$ \\
\hline
\end{tabular}




\begin{tabular}{|c|c|c|c|c|}
\hline & & & & markets. \\
\hline Coeurderoy \& Murray & 2008 & $\begin{array}{l}\text { Britain, } \\
\text { Germany }\end{array}$ & $\begin{array}{l}\text { New-tech } \\
\text { firms }\end{array}$ & $\begin{array}{l}\text { +ve impact of intellectual } \\
\text { property protection; } \\
\text { moderating impact of home } \\
\text { country regulatory regime. }\end{array}$ \\
\hline Dowell \& Killaly & 2008 & USA & Telecom firms & $\begin{array}{l}\text {-ve effect of frequency and } \\
\text { amplitude of market } \\
\text { resource variation of a host } \\
\text { country. Experience in the } \\
\text { host country moderates the } \\
\text { relationship. }\end{array}$ \\
\hline Ellis & 2008 & China & Exporters & $\begin{array}{l}\text { Psychic distance moderates } \\
\text { the relationship between } \\
\text { market size and entry } \\
\text { sequence. }\end{array}$ \\
\hline $\begin{array}{l}\text { Hutzschenreuter \& } \\
\text { Voll }\end{array}$ & 2008 & Germany & MNEs & $\begin{array}{l}\text {-ve effect of expansion } \\
\text { moves with high levels of } \\
\text { added cultural distance per } \\
\text { unit of time and irregular } \\
\text { moves in culturally distant } \\
\text { nations on profitability. }\end{array}$ \\
\hline $\begin{array}{l}\text { Nachum, Zaheer, \& } \\
\text { Gross }\end{array}$ & 2008 & USA & MNEs & $\begin{array}{l}\text { +ve impact of geographic } \\
\text { proximity to centers of } \\
\text { knowledge, markets and } \\
\text { resources }\end{array}$ \\
\hline Rose \& Ito & 2008 & Japan & Automobile & $\begin{array}{l}\text { Bandwagon effect is not } \\
\text { universal in oligopolistic }\end{array}$ \\
\hline
\end{tabular}




\begin{tabular}{|l|l|l|l|l|}
\hline & & & & industries \\
\hline Wang \& Schaan & 2008 & Japan & MNEs & Non-linear relationship \\
& & & & between cultural distance \\
and performance
\end{tabular}

It can be observed from the above table that the literature on location determinant has been developing for the past thirty years and results still pose a potential to enrich it further. It can be further interpreted from the table and literature review that the host country location determinants may broadly be classified into the following seven categories:

(i) four types of distances namely psychic distance, cultural distance, geographic distance, and economic distance;

(ii) three types of institutional environment namely regulatory institutions, political institutions, and societal institutions;

(iii) experiential learning and managers' background;

(iv) agglomeration;

(v) macroeconomic factors;

(vi) customer or partner following; and

(vii) availability of natural resources.

A further review of each of these categories is given below.

(i) Distance: Distance in the field of international business may be of four types, namely psychic distance, cultural distance, geographic distance and economic distance. Ghemawat (2001) proposed another type of distance, namely administrative distance in his CAGE distance model. But administrative distance has found only limited use in the literature on "location determinants". Hence, administrative distance is not used in the dissertation.

Psychic Distance: The term psychic distance is coined by Beckerman (1956), but used formally in IB by Johanson and Weidersheim-Paul (1975) and Johanson and Vahlne (1977). Psychic distance includes differences in language, business practices, political systems, religion etc. (Johanson \& Vahlne, 1990). 
Psychic distance may be one of the reasons as to why the biggest multinational firms still derive majority of their revenue from one (Rugman \& Verbeke, 2004) or two regions (Dunning, Fujita, \& Yakova, 2007).

Johanson and Weidersheim-Paul (1975) and Johanson and Vahlne (1977) studied the location choice of Swedish firms in their initial stage of internationalization. They suggested that the process of internationalization is fraught with uncertainties of various kinds which can be reduced only by knowledge acquired by conducting overseas operations. These uncertainties deter the host country location choice of an internationalizing firm such that a firm starts with countries that are closer to its home country in terms of geographic and psychic distance.

Results of studies on psychic distance and sequence of foreign market entry have been inconclusive. Dow and Karunaratna (2006) summarize that there is a debate about psychic distance as to "what constitutes it", whether it should be measured using objective measures or using perceptions of individuals and propose a construct called "psychic distance stimuli" to hopefully end this debate. Dow and Karunaratna (2006) split psychic distance into (i) psychic distance stimuli using educational, cultural and religious distance, and former colonial ties and degree of democracy, and (ii) perceived psychic distance as perceived by managers since the managers select the host country location. In a recent study on 924 international entry sequence of 73 Chinese exporters, Ellis (2008) proposed that psychic distance cannot be the cause of foreign direct investment which is a big financial investment with long-term investment. The author showed psychic distance to act as a moderator between the relationship of foreign market size and location choice, challenging the direct effect of psychic distance (Ellis, 2008).

Cultural distance: This factor has been shown to directly influence the FDI rate (Grosse \& Trevino, 1996; Li \& Guisinger, 1992) or moderate the relationship between market size and FDI location (Flores \& Aguilera, 2007). Cultural distance punctuates organization's learning in different countries and cultural blocks (Barkema, Bell, \& Pennings, 1996) and was significant for successful international joint venture operations of Dutch firms in developing countries but not in developed countries (Barkema, Shenkar, Vermeulen, \& Bell, 1997). Relational linkages based on ethnic ties and cultural similarity promoted the international growth of Taiwanese and Singaporean firms in China and South East Asia by minimizing transaction and coordination costs (Hsing, 1996; Yeung, 2000). Individual dimensions of 
culture affect differently the international locations of firms. Firms prefer to locate in those countries that have cultures marked with low levels of uncertainty avoidance and high levels of trust (Bhardwaj, Dietz, \& Beamish, 2007).

A study using data of 2404 expansion moves by 91 German multinationals whose international expansion was tracked for 5 to 20 years examined that the firms making expansion moves involving a high level of added cultural distance per unit of time and the firms expanding in culturally distant countries in irregular fashion exhibit less profitability (Hutzschenreuter \& Voll, 2008). Similarly, a foreign direct investment data of Japanese firms in 53 countries covering 36 years of their foreign expansion moves illustrated that cultural distance and profitability had inverted U-shaped relationship (Wang \& Schaan, 2008).

However, a recent meta-analysis found only the moderating effect of cultural distance on international diversification depending upon the level of technological intensity of an industry and only for recent samples which may indicate that firms are diversifying into culturally distant countries (Tihanyi, Griffith, \& Russell, 2005). Managers create framework to understand a different culture and can manage those cultural distances where they understand the bilateral cultural differences (Chapman, Gajewska-De, Clegg, \& Buckley, 2008).

Geographic Distance: Outward FDI of Korean firms was deterred by the geographic distance in initial stages of internationalization (Erramilli, Srivastava, \& Kim, 1999). Geographic distance was found to be a factor affecting inward FDI in Mexico (Thomas \& Grosse, 2001). A country's proximity to global distribution of knowledge, markets and resources may promote FDI in that country (Grosse \& Trevino, 1996; Nachum et al., 2008), but the result was found to be more pronounced for smaller firms than larger firms (Nachum et al., 2008).

Economic Distance: Ghemawat (2001) proposed economic distance which includes difference in wages and technological capabilities of the two countries. Several multilatinas began their international journeys with economically closer markets (Curevo-Cazurra, 2008a). But another study found that FDI hazard rates are lower in countries with more or less economic development than in countries with the similar level of economic development (Tsang \& Yip, 2007). 
(ii) Institutional environment: Firms value those institutional environments that make them exploit their competitive advantages in host countries (Dunning, 1998). Multinational firms are advised to locate in countries with low institutional differences as firms need to conform to the local institutions (Trevino \& Mixon, 2004). Institutional compatibility in the location portfolio of a multinational firm increases its ability to benefit from knowledge flows among its various nodes (Dunning, 2009; Kostova, 1999; Kostova, Roth, \& Dacin, 2008; Kostova \& Zaheer, 1999). Failure to embed in local institutions led to failure of many multinational retail giants in Chile (Bianchi \& Ostale, 2005). As per neo-classical economics, institution of a country has three dimensions, namely regulatory, political and societal (North, 1990).

Regulatory Institutions: Government regulations affect the growth of firms (Capelleras, Mole, Greene, \& Storey, 2008). Internationalization paths are considered as outcome of assessment of transaction cost and risks (Buckley \& Casson, 1976). Effectiveness of laws pertaining to intellectual property rights influence the international location choice of American firms (Globerman \& Shapiro, 2003), and German and British new-tech firms (Coeurderoy \& Murray, 2008). The relationship was moderated by similarity in home and host country legal regime (Coeurderoy \& Murray, 2008).

Political institutions: Policy environment of a country includes its set of laws, regulations, administrative procedures, and policies formally sanctioned by the government that impact a firm's profitability by altering its costs and revenue (Delios \& Henisz, 2003b). Uncertainty in policy environment, degree of corruption, and opaqueness in government and legal processes make a country politically hazardous (Henisz, 2000) and can deter FDI (Delios \& Henisz, 2003a; Dunning, 2009; Globerman \& Shapiro, 2003; Henisz \& Delios, 2001; MacCarthy \& Athirawong, 2003; Woodward \& Rolfe, 1993). Political risk has been shown to moderate the relationship between market size and FDI location (Flores \& Aguilera, 2007).

Among different constituents of political institutions, corruption has received special attention in location literature. Corruption can be pervasive or arbitrary (Rodriguez, Unlenbruck, \& Eden, 2005). Corruption in a host country affects the sources of inward FDI whereby attracting higher FDI from countries where corruption is high (Cuervo-Cazzura, 2006). It poses a negative trade-off between marketattractiveness and FDI (Grosse \& Trevino, 2005; Wei, 2000), but does not deter FDI when corruption is 
arbitrary rather than pervasive (Cuervo-Cazurra, 2008). Multinational firms take recourse under entry modes such as short-term contracting or joint ventures to adapt to corruption in host countries (Uhlenbruck, Rodriguez, Doh, \& Eden, 2006). Moreover, corruption affects resource-seeking but not market-seeking FDI (Brouthers, Gao, \& Mcnicol, 2008). A country's level of political constraints and economic development negatively affect the bribery activity of local firms (Husted, 1999; Martin, Cullen, Johnson, \& Parboteeah, 2007). As emerging markets have fewer political constraints and lower economic development than the developed countries (Henisz, 2000), firms from emerging markets are likely to engage in bribery and are likely to remain undeterred by the level of corruption in a host country. Corruption is said to be rampant in Asian countries (Luo, 2002). Thus, level of corruption is unlikely to be a factor affecting the location choice of EMFs.

Societal institutions: Societal trust has been shown to moderate the relationship between market size and FDI location (Flores \& Aguilera, 2007). Xu and Shenkar (2002) used the sociological dimensions of institutions, namely cognitive, normative and regulative to propose that (i) multinationals with routinebased advantage are likely to enter normatively proximate market, (ii) multinationals following global strategy are likely to enter normatively and cognitively closer markets, and (iii) multinationals with multidomestic strategy are likely to enter distant normative and cognitive markets.

(iii) Experiential learning and managers' background: Experiential learning has been highlighted and oft-researched in International Business literature (Hutzschenreuter, Pedersen, \& Volberda, 2007). Prior investment and duration of stay in a host country increases the probabilities of further investment in the same host country (Erramilli, 1992; Mudambi, 1998) and survival rate (Shaver, Mitchell, \& Yeung, 1997), even in host countries with high frequency and amplitude of changes in resource environment (Dowell \& Killaly, 2008). Relevant types of international experiences turn firms less sensitive to the deterring effects of uncertain policy environments on investment (Delios \& Henisz, 2003; Henisz \& Macher, 2004) but still a firm needs to balance exploitation of its experience in a host country or its region and exploration of new geographies while making a host country selection (Barkema \& Drogendijk, 2007). Experience engenders time-based and transfer-based learnings which ease the process of cross-border tacit 
knowledge transfer, increasing a firm's propensity to set up manufacturing plants in a foreign location (Martin \& Salomon, 2003).

An under-researched determinant of the international paths of firms is about managers' background (Coeurderoy \& Murray, 2008; Hutzschenreuter et al., 2007). Top management characteristics such as international experience, higher elite education, lower average age, and higher average tenure are positively related to firm's international diversification (Sambharya, 1996; Tihanyi, Ellstrand, Daily, \& Dalton, 2000). Managers with more international experience seem to provide consistent models of countryselection and appear to be less risk-averse in making decisions (Buckley et. al, 2007). Top management team's educational and tenure heterogeneity, and international experience are shown to be positively related to a firm's global strategic posture which has three dimensions, namely foreign sales, foreign production and geographic diversity (Carpenter \& Fredrickson, 2001). Governance issues such as family, non-family insiders such as directors and CEOs and institutional shareholding pattern are found to impact the location choices of Taiwanese firms into China (Filatotchev et. al, 2007).

(iv) Agglomeration: As knowledge-intensive, innovative and entrepreneurial activities become geographically concentrated in clusters due to cross-border differences in institutional and human environments (Breschi \& Malerba, 2001; Cantwell, 1995; Cantwell, 2009; Dunning, 2009); multinational firms agglomerate in these clusters for network externalities (Almeida, 1996; Almeida \& Phene, 2004; Baum, Li, \& Usher, 2000; Frost, 2001; Krugman, 1991; Jaffe, Hendersen \& Trajtenberg, 1993; Marshall, 1920; McCann \& Folta, 2008; McCann \& Mudambi, 2004; Mudambi, 2008; Nachum, 2000; Phene \& Almeida, 2008; Porter, 2000; Saxenian, 1996; Smith \& Florida, 1994). Firms also agglomerate when prior stock of investment by multinationals in a host country gives signals to other firms to locate there (Dunning, 1998).

Another reason for agglomeration to occur is when firms imitate each other in order to gain legitimacy or reduce uncertainty associated with internationalization (DiMaggio \& Powell, 1983; Gimeno et. al, 2005; Levitt \& March, 1988; Suchman, 1995) or when firms are under pressures of oligopolistic rivalry or face multimarket contact (Ghemawat \& Thomas, 2008; Graham, 1978; Haveman \& Nonnemaker, 2000; Knickerbocker, 1973). International firms are attracted to a host country for any of these reasons. 
Firms are shown to avoid agglomeration too, depending upon their status as a leader or laggard (Shaver \& Flyer, 2000), and the extent of their R\&D or product differentiation (Chung \& Alcacer, 2002; Nachum \& Wymbs, 2005). A further detail is given below.

Network Externalities: Domestic and international firms co-locate to increase their learning (Almeida, 1996; Baum et al., 2000; Jaffe et al., 1993) or competence by undertaking specific activities at a particular location by taking advantage of spatially-embedded resources (Cantwell, 2009; Cantwell \& Mudambi, 2005; Dunning, 2009; Nachum \& Zaheer, 2005; Porter, 2000). Strong network externalities are found within firms than across firms, from firms in the same industry than firms from different industries, and from firms of same nationality than firms from different nationalities (Henisz \& Delios, 2001).

Relationship of network externalities and location choice is shown to be both positive and negative (Aharonson, Baum, \& Feldman, 2007; Alcacer, 2006; Baum \& Haveman, 1997; Baum \& Mezias, 1992; Chung \& Kalnins, 2001; Shaver \& Flyer, 2000). First time entrants into the USA markets during 1985-94 located to maximize their net spillovers as a function of location's knowledge activity, their own capabilities and competitor's anticipated actions (Alcacer \& Chung, 2007). A recent study demonstrated curvilinear relationship between network externalities and the likelihood of co-location (Chang \& Park, 2005). The sales and production subsidiaries were illustrated to be more geographically dispersed while $R \& D$ subsidiaries were more concentrated in worldwide cellular handset industry in year 2000 (Alcacer, 2006).

Imitation: Guillen (2002) showed that emerging market multinationals which are in early stage of internationalization imitated other firms in making the location decisions.

Industrial Oligopolistic Rivalry or Multimarket Contact: Competition determines the co-location of firms in a host country (Flowers, 1976; Haveman \& Nonnemaker, 2000; Hennart \& Park, 1994; Li \& Guisinger, 1992; Ito \& Rose, 2002; Knickerbocker, 1973; Sethi et al., 2003;Yu \& Ito, 1988). Knickerboker (1973) theorized that FDI is the result of an oligopolistic reaction to other competitors, producing a bandwagon effect. The host country location choice of global tire firms and Japanese largest automobile firms is guided by the presence of their domestic rivals in the host country (Ito \& Rose, 2002; Rose \& Ito, 2008). The authors illustrated that these firms competed in some key markets but avoided unnecessary 
competition in other markets (Rose \& Ito, 2008). Similarly, international location choice of six largest multinationals in cement industry is explained with help of rivalry resulting from multimarket contact (Ghemawat \& Thomas, 2008).

(v) Macroeconomic factors: It includes market size and market growth, barriers to trade, costs of labor and other resources, transportation and information costs and availability of infrastructure such as energy, roads and communication; government's initiatives, and trade and tax regulations. Exchange rates also affect location decisions (Dixit, 1989). It is highly likely that different internationalization strategies may make some macroeconomic factors more salient in location choice than others.

(vi) Customer or Partner following: Firms, especially in services sector and business networks follow abroad their customers or business partners (Chen \& Chen, 1998; Hennart \& Park, 1994; Li \& Guisinger, 1992; Martin, Swaminathan, \& Mitchell, 1998; Miller \& Parkhe, 1998; Nigh, 1985; Petrou, 2007; Yamori, 1998).

(vii) Availability of natural resources: Dunning (2009) expects a continued renaissance in naturalresource-seeking FDI especially by emerging market and emerging transition market firms.

It can be observed further from the literature review that only a few empirical studies have examined the location choices of EMFs. Almost all of these studies have used categorical variables to divide the host countries into two basic categories of developed or developing countries. For example, Erramilli et al. (1997) proposed that EMFs may find themselves into two kinds of markets: those that are more advanced or less advanced than their own market. Aulakh et al. (2000) studied relationship between the location choice of and strategies for host countries by Latin American firms and categorized the host countries as developed or other developing countries. Makino et al. (2002) suggest that Taiwanese firms can go to either developed countries or less developed countries. Makino et al. (2004) suggest that a developed country firm can go either to another developed country or to a less developed country which includes emerging markets, and least developed countries. A special issue in Journal of Management Studies (2005) edited by Wright et al. suggests that EMFs can go to other emerging markets and developed countries. 
EMFs are unlikely to consider all seven categories of host country location determinants proposed above. For example, experiential learning and managerial background may not be as important a determinant for EMFs at this point in time, as these firms are in their initial stages of internationalization. Moreover, availability of natural resources or customer or partner following is unlikely to affect the location decisions of Indian software firms. Consequently, the dissertation controls for the remaining four categories, namely distance, institutions, agglomeration, and macroeconomic factors.

To understand the location choice of Indian software firms in the dissertation, a two-way categorization of various countries (either developed or emerging market countries) is used by proposing that Indian software firms can internationalize by seeking to enter either developed countries or other emerging markets. NICs are clubbed with developed countries in the dissertation. It is highly unlikely that Indian software firms would be locating in the least developed countries at this time because of market and resource configurations in these countries. It is believed that the two-way categorization would help understand the research question better as the factors that impede or facilitate internationalization such as economic, institutional, societal, and resource environments are different in these two categories of countries. 


\section{CHAPTER VI}

\section{MODEL AND HYPOTHESES}

It can be observed from the literature reviews in chapters 2-5 that EMFs possess different types of resources and internationalization strategies. Further, it can be observed that there are limited studies that researched the host country location determinants of EMFs. Specially, the question as to what location determinants EMFs consider for choosing a host country location has not been addressed well by scholars. Also, how EMFs' resource types and internationalization strategies affect the location choice have received limited scholarly attention.

The conceptual model presented in this dissertation examines the impact of the above-mentioned variables, namely resources and internationalization strategies on the location choices of EMFs. The conceptual model proposed in the dissertation argues that resource types of EMFs, namely relational resources (which are non-market resources, ethnic relational resources, business relational resources), market-knowledge resources, process resources, and natural-asset based resources, determine the internationalization strategies, namely market-seeking, efficiency-seeking, asset-seeking, resource-seeking, or opportunity-seeking, to be adopted by the EMFs in their overseas journey. For example, EMFs with business relational resources may go international with a market-seeking or an asset-seeking strategy, whereas EMFs with natural asset based resources may go international with market-seeking or resourceseeking strategy. On the other hand, EMFs with non-market resources may go overseas mainly with market-seeking strategy.

Further, the model suggests that the internationalization strategies of the EMFs will directly affect the host country location choice, after controlling for various location determinants. The model further proposes that the direct relationship between EMF's internationalization strategy and the location choice will be moderated by the resource type possessed by the EMF. Thus, it is not necessary that all EMFs with market-seeking strategy will choose the same location. The location choice is decided by the combination of resource type and internationalization strategy of the EMF. For example, a market-seeking EMF with non-market resources and another market-seeking EMF with business relational resources will make

different location decisions. The former may locate in an emerging market where it can advantageously 
deploy and exploit its non-market resources whereas the latter may locate in a country where its major customer opens up operations. That country could be developed nation or another emerging market.

Similarly, a market-seeking EMF with ethnic relational resource will mainly locate in a country where the size of the ethnic population is among the largest because it may target to sell its product to the ethnic population in the host country, and this host country could be a developed nation or another emerging market or a least developed nation.

Model

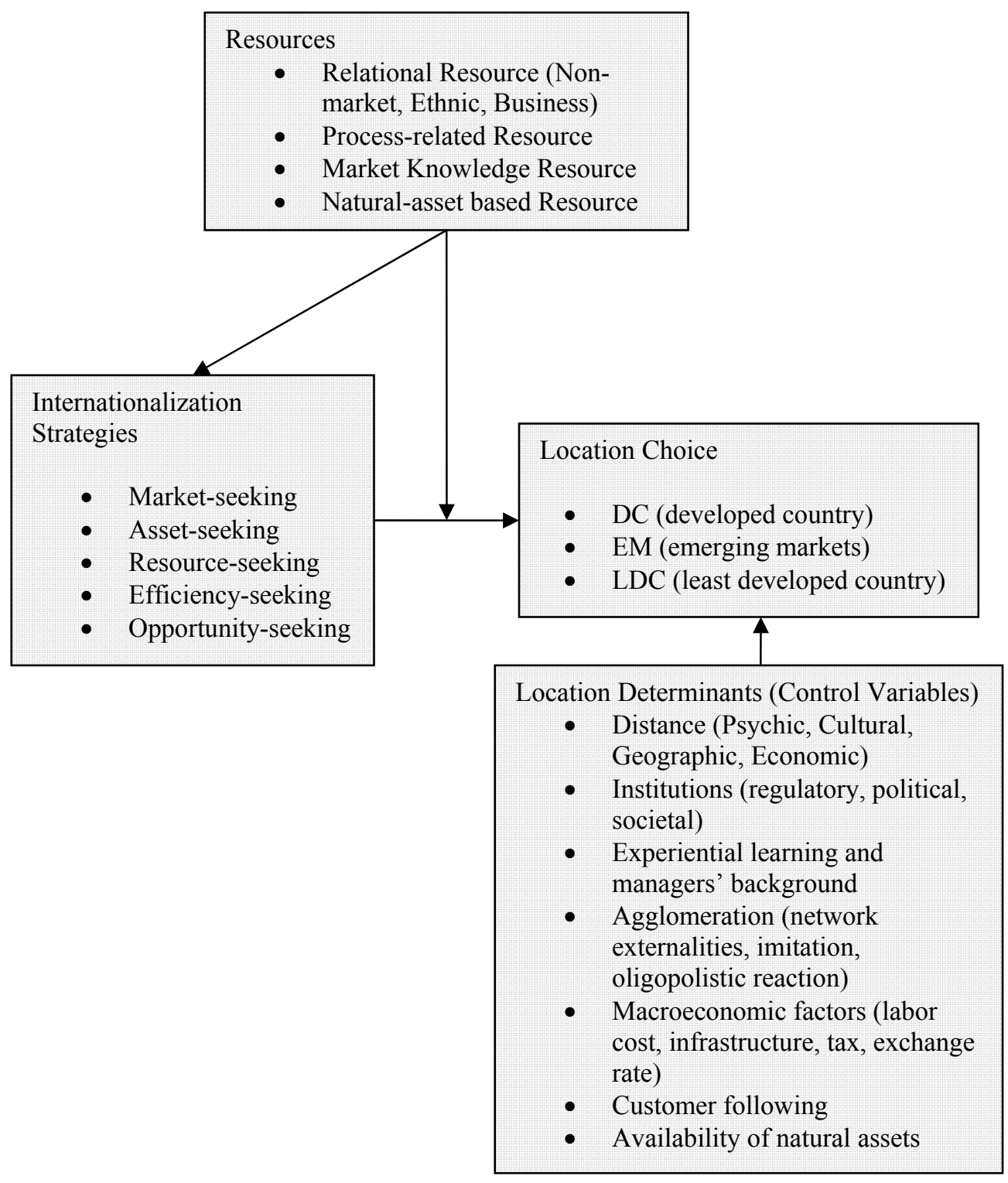


Some scholars such as Cuervo-Cazurra (2007), Makino et al. (2002), Sethi et al. (2003), and Xu and Shenkar (2002) have investigated relationships among some variables that form part of the model described in the preceding paragraphs. Makino et al. (2002) study the relationships among home country factors, firm's internationalization strategies and capabilities on the host country location choices of firms from Taiwan. These authors, however, do not discuss the role played by the location determinants.

Moreover, the host countries are divided into developed or the least developed countries in the said study. Cuervo-Cazurra (2007) employs the eclectic paradigm of international production to explain the relationship between the firm capabilities derived from home or host country assets and the internationalization strategies chosen by multilatinas investing in other Latin American countries. CuervoCazurra (2007), however, studies a sub-segment of the comprehensive model proposed in this dissertation and his coverage of FDI location is restricted to the Latin American countries. Sethi et al. (2003) study, as one of the relationships in their model, the effect of efficiency-seeking and market-seeking internationalization strategies on the location determinants considered by the US multinationals. The focus of their study, however, is to examine the changing trends in flow and determinants of US FDI as a result of macro-economic and firm strategy considerations. The emphasis of Xu and Shenkar (2002) is to explore conceptually the effect of normative, regulatory and cognitive dimensions of institutional distance as a location determinant on various aspects of FDI by multinationals. As part of their model, these authors propose a relationship between institutional distance as a location determinant and resource-types of multinational firms.

Based on the above discussion, it can be concluded that these studies do not examine the simultaneous effect of firm resources and internationalization strategies on the host country location choice, after controlling for various location determinants. Dunning and Lundan (2008), in their eclectic paradigm of international production propose that the firms' internationalization strategies, resources and the location determinants chosen by firms affect the international production decision of firms; they fall short of proposing a model that delineates specific relationships among these variables. Furthermore, the eclectic paradigm of international production does not include the host country location chosen by the firm as one of the variables in the framework. For example, it does not discuss whether firms will locate in developed 
countries, NICs, or emerging markets to follow any specific internationalization strategy. The eclectic paradigm of international production as a framework, however, provides a basis to study the model proposed in the dissertation as this framework suggests that there exists a relationship among resources, internationalization strategies and host country location determinants of a firm and these variables also form part of the model discussed in this dissertation. Hence, the eclectic paradigm of international production can provide guidance to delineate relationships among the variables.

Before specific hypotheses are proposed, it is important to understand if EMFs have a resource portfolio consisting of more than one resource out of the relational resources (which are further of three types namely non-market, ethnic, and business relational resource), market-knowledge resources, processrelated resources, and natural-asset based resources; and if these organizations use more than one resource in order to internationalize as it has become tough to internationalize based on a single advantage (Aulakh et al., 2000). For example, Indian software, besides process-related resource, have also been said to use ethnic relational resource (Kapur \& Ramamurti, 2001) and business relational resource (Elango \& Pattanaik, 2007) to internationalize. To understand what resources have been utilized by the sampled Indian software firms in their internationalization effort, a short questionnaire is administered to top and senior managers of the sampled Indian software companies. In each company, two managers are asked to rate on a scale of 1-5 the importance of various resources namely the three types of relational resources, marketknowledge resources, process-related resources, and natural-asset based resources that have helped their organizations internationalize. The survey results demonstrate that majority of these firms utilize one resource predominantly to locate in a specific location. It can be further noted from the survey result that 52 of the 64 contacted managers, forming $81.25 \%$ of the respondents rate process-related resources as the most important resource that helped their company internationalize. Thus, it is proposed in this dissertation that the key resource of Indian software firms that motivated them to internationalize and start looking outward is process-related resource. This assumption helps make the model simpler and parsimonious. Internationalization Strategies and Location Choices of Indian Software Firms.

Resources of a firm provide sustainable competitive advantage to the firm in the marketplace (Barney, 1991) and guide its strategy (Malik, 2008; Noda \& Bower, 1996; Papadakis, Lioukas, \& 
Chambers, 1998; Prahalad \& Hamel, 1990; Tseng et al., 2007). Firm-specific resources may be advantageous and fungible to varying degrees when transferred to another host country due to institutional, economic or social environmental dissimilarities between home and host countries (Anand \& Delios, 1997; Buckley \& Casson, 1996; Cuervo-Cazurra, 2007; Erramilli et al., 1997; Miller \& Shamsie, 1996; Rugman \& Verbeke, 1992). Thus, firms are likely to choose different internationalization strategies in different international markets to match their resources and overcome the disadvantages in a host country. Consequently, there may be heterogeneity in firms' internationalization strategies depending upon their resource configurations.

Indian software firms may locate in international markets with a market-seeking strategy or augment their resource base with a labor-seeking strategy. Process-related resources possessed by Indian software firms have enabled these firms to offer low cost alternatives to the standardized and mature products. Indian software firms have excelled in offshore codification of the standardized processes of multinational firms. The value-proposition created on strength of process-related resources has made these firms internationally competitive. The process-related resources may be fungible in different institutional environments since the customers mainly derive value from the low-cost offerings of these EMFs.

It has been observed that high wages in developed countries made multinational firms in these countries look for low-cost alternatives when they are developing software to automate their processes (Doh, 2005). Indian software companies have the potential to fill this gap and offer low cost solutions to the large multinational firms in developed nations. Firms in emerging markets may not face as much cost pressure as developed nation firms do, though the former set of firms may be motivated to harness the advantage of information technology in order to increase their competitive advantage. However, the market in emerging countries is not likely to be as big or profitable as in developed countries. Thus, the processrelated resources of Indian software firms are likely to be advantageous in their international journey by helping them overcome liabilities of foreignness in developed nations, and by increasing their international sales and profitability, which is the prime objective of a market-seeking strategy (Dunning, 1983).

Indian software firms are likely to face competition from firms from other countries that have availability of skilled but cheap manpower. At the same time, the growth of Indian software firms has 
resulted in recruitment of talented Indian engineers in large numbers which has scaled up the wages in India (Doh, 2005; Scheiber, 2004). The salaries in India have been moving up in double digits for last several years (Economist, 2006) and are forecast to show a similar trend at least until 2011 (Minder, 2008). Consequently, Indian software firms may face shortages of skilled labor in their home country and the costarbitrage opportunity available to these firms may shrink with the upward movement of the labor cost. Hence, to sustain their international competitiveness, Indian software firms need to augment their resource base with a labor-seeking strategy (Dunning, 2006; Sethi et al, 2003). For example, many Japanese firms moved out of Taiwan to locate in Malaysia when the labor cost went up in Taiwan (Song, 2002).

Developed countries offer abundant skilled labor but at a high cost. Some emerging markets offer affordable skilled labor such that locating with a labor-seeking strategy in those nations has the potential to serve or maintain the cost differential, one of the drivers of offshoring. Indian software firms are unlikely to face a big liability of foreignness in other emerging markets as the economic conditions there are similar to India. Moreover, the past international experience of Indian software companies, though in developed nations, may have built in these firms some managerial skills required to coordinate dispersed teams and increased their knowledge stock about the unique business environments in other countries. International experience also prepares the managers to overcome the complexities inherent in an international expansion (Zahra, 2003). Consequently, several Indian software firms have set up operations in other countries such as Mexico, Malaysia, and China to tap the human resources there, which is the prime motive behind a labor-seeking strategy (Dunning, 1983). Hence, the following is proposed:

Hypothesis 1: Among Indian software firms, those pursuing a market-seeking strategy are more likely to locate in a developed country than those pursuing a labor-seeking strategy, which in turn, are more likely to locate in an emerging country.

To study the impact of resources on the location decisions of Indian software companies, it is important to comprehend what variables constitute the construct called process-related resources. To understand and establish the content validity of the construct of process-related resource in the context of Indian software firms, the industry experts and the top managers of some of the largest Indian software companies were contacted. Based on discussions with them, the process-related resources that are 
responsible for the remarkable success of Indian software companies may have the following three dimensions:

- Knowledge management by the software vendor firm,

- Internal processes of the software vendor firm to deliver quality goods to the client,

- Low cost but qualified human talent with the software vendor firm.

Each of these resources and its impact on location decision is detailed below.

Electronic Knowledge Sharing Database as a Resource and Location Choice

Knowledge sharing in an organization benefits it in many ways such as by enhancing customer satisfaction or reducing costs (Nonaka, 1994). An absence of knowledge sharing in an organization may result in missed opportunities and inefficiencies (Milliken, Morrison, \& Hewlin, 2003). A study by Babcock (2004) reports that Fortune 500 companies may loose at least USD 31.5 billion a year if employees fail to share knowledge.

An effective approach adopted by multinational firms to capture knowledge sharing may be to establish an electronic knowledge sharing database. A knowledge sharing database provides organizationwide information at a click and makes it easier for employees to access and contribute to the information. In a software company, a knowledge sharing database may help a project team by informing it of clientspecific knowledge if the firm has worked with the same client in the past, or project-specific knowledge if the firm has worked on a similar project in the past, or any other technology-related information vital to the successful completion of the project. Ready availability of client or project specific knowledge may lower the effort, elapsed time, and rework - the hallmark of a successful offshoring project (Gopal, Mukhopadhyay, \& Krishnan, 2002). A knowledge management database by codifying the knowledge may contribute in an effective manner to the success of a software project where project team members often work with each other in distributed location settings and different time zones which may have adverse impact on knowledge sharing among employees. Thus, a knowledge sharing database may assist the project team in completing the project within envisaged time and cost budgets, and may enhance the client satisfaction with the vendor software company. No wonder, Dyer \& Singh (1998) and Tallman, Jenkins, 
Henry \& Pinch (2004) report increase in the competitive advantage of the firms that effectively implement knowledge sharing practices among their employees.

Despite these obvious benefits, not all companies can successfully implement and document knowledge sharing among their employees (Lepak \& Snell, 1999) because firms may lack organizational mechanisms (Majchrzak, Rice, King, Malhotra, \& Ba, 2000), technological resources that help employees share knowledge (Fulk, Flanagin, Monge, \& Bar, 2004) or an organization culture conducive to motivate employees to share knowledge (Bock, Zmud, Kim \& Lee, 2005). Thus, an electronic knowledge sharing database may act as a competitive enhancing resource for a firm.

As the expertise residing in an organization can be harnessed and put to use effectively with the aid of an electronic knowledge sharing database, a vendor Indian software company, by effectively tapping the expertise within the organization, can ride the experience curve to lower its cost of project and deliver the software product within the time schedules originally decided with a client. Such vendor companies can lay credible claims to client companies distantly located in developed markets and may sound more convincing to client companies considering automating their processes than a vendor software company that does not possess an electronic knowledge sharing database. Gaining client credibility is imperative because outsourcing decision by a client company is a complex and daunting task (Aydin \& Bakker, 2008) and may deter the latter to engage in offshoring projects. Moreover, a vendor software company that possesses a knowledge sharing database is more likely to offer know-how to the client company facing knowledge drain occurring at its premises because of downsizing or outsourcing business activity than a vendor company that does not possess knowledge sharing database (Aydin \& Bakker, 2008).

Though developed countries offer bigger markets for software firms than emerging markets, the former are highly competitive. Developed countries see many big multinational vendor software firms such as IBM etc. competing fiercely for large and prestigious projects initiated by large multinational client companies. Many of the client companies have several years of experience in offshoring and have the expertise to assess the capabilities of vendor companies. Hence, it is possible that the Indian software firms that possess a knowledge sharing database will have an increased tendency to locate in developed countries with a market-seeking strategy than firms that do not possess a knowledge sharing database. However, as 
the Indian software firms that do not possess a knowledge sharing database have an already high likelihood of locating in a developed country with a market-seeking strategy, the increased propensity of firms with a knowledge sharing database to locate in a developed country with a market-seeking purpose is unlikely to be much higher than for firms without such a database. Hence, the effect may not be observable in the case of market-seeking strategies of Indian software firms.

On the contrary, the interaction effect will be pronounced in case of a labor-seeking behavior of the two set of firms. Since, by virtue of having the potential to lower their costs by effectively harnessing the knowledge distributed in various pockets of the organization, an Indian software firm with a knowledge sharing database may be able to set up a global delivery center in a developed country and still be cost competitive. Locating with a labor-seeking strategy in close vicinity of its client companies in a developed nation may enable the vendor software company to serve its client companies more effectively than a vendor company that does not locate proximally to the client company. Thus, a knowledge sharing databse is likely to enable an Indian software firm to locate in a developed country with a labor-seeking strategy. Hence, the following is argued.

Hypothesis 2: Among Indian software firms, the relationship between their strategy-type and location choice will be moderated by the possession of an electronic knowledge sharing database, such that a firm that possesses the database will show more likelihood to locate in a developed country than one without the database when its strategy-type is labor-seeking, but not when its strategy-type is market-seeking.

Low Cost of Software Production as a Resource and Location Choice

The high cost of production in developed countries due to high wages has boosted the offshoring of IT work to emerging countries such as India (D’Costa, 2004). However, over a period of time, the wages in India have seen a steady increase in the software industry (Doh, 2005; Scheiber, 2004). This may render many Indian software companies uncompetitive to locate in developed markets with a market-seeking strategy. Unaffordability of an expensive IT solution and unclear associated cost-benefit advantages may deter client companies to engage in IT offshoring projects. It is interesting to note that the firms that have managed their labor bills efficiently also happen to be some of the most reputed Indian software companies. 
Their brand-names, good organization culture, and reputation to offer professional growth to their employees may have helped these companies attract the best talent but at competitive rates. Hence, the Indian software companies that have been able to keep their labor cost low may find themselves in a competitive advantageous position to serve developed markets than the firms that have not been able to do so. Hence, the Indian software firms that have low wage bills will have an increased tendency to locate in developed countries with a market-seeking strategy than the firms that have high wage bills. However, as the Indian software firms that have high wage bills are likely to have an already high likelihood of locating in a developed country with a market-seeking strategy, the increased propensity of firms with low wage bills to locate in a developed country with a market-seeking purpose is unlikely to be much higher than for firms with high wage bills. Hence, the effect may not be observable in case of market-seeking strategies of Indian software firms.

On the contrary, the interaction effect is likely to be observable in case of a labor-seeking behavior of the two set of firms. Indian software companies that have kept their wage bills low may be in a more comfortable position to locate in developed countries with a labor-seeking strategy than the companies whose wage bills are high. Opening global delivery centers in developed countries can improve communication, coordination, and conflict resolution between client and vendor companies resulting in an increased psychological contract between the two (Miranda \& Kavan, 2005), reduced project uncertainties, and improved performance (Gopal et. al, 2002). Locating in a developed nation with a labor-seeking strategy may enable client and vendor companies to build relational capital and trust that positively affect the client's propensity to outsource (Holcomb \& Hitt, 2007; Miranda \& Kavan, 2005). However, locating in a developed market with labor-seeking strategy can push the wage bills even higher for those vendor companies that already have higher wage bills because the labor cost is high in developed nations. A high wage bill may turn these vendor companies uncompetitive in the offshoring business - a trend that was observed in Ireland (Doh, 2005). On the contrary, firms with low wage bills may be able to soft-land against the impact of high wages when they locate in a developed country with labor-seeking strategy. Therefore, Indian software companies with high wage bills are not as likely to locate in developed markets with labor-seeking strategies as an Indian software firm with low wage bill. Hence the following is argued. 
Hypothesis 3: Among Indian software firms, the relationship between their strategy-type and location choice will be moderated by wage bill, such that a firm with low wage bill will show more likelihood to locate in a developed country than one with high wage bill when its strategytype is labor-seeking, but not when its strategy-type is market-seeking.

Process Improvement Implementation as a Resource and Location Choice

The capability maturity model integration (CMMI) in software engineering is a process improvement approach which supports project teams, departments or entire organizations in improving their internal processes by providing them guidance and reference points. An organization is appraised at various CMMI maturity levels ranging from 1 to 5 , with level 5 being the highest achievable level (http://www.sei.cmu.edu/cmmi/index.cfm. accessed on December 29, 2009). The CMMI appraisal is being adopted worldwide and is typically carried out by an independent consulting or auditing firm trained by Software Engineering Institute. CMMI may improve a firm's coordination capabilities required to manage a set of geographically dispersed activities. CMMI infuses a firm with disciplined processes which pay off by increasing a project success rate by impacting the rework, elapsed time and effort required to complete the project (Gopal et. al, 2002).

Software offshoring firms seek the CMMI appraisal voluntarily as CMMI employs systems engineering principles in software development resulting in improved performance for software firms. Thus, CMMI appraisal has become the most well-known certification standard in the context of the IT offshoring industry worldwide (Herbsleb, Zubrow, Goldenson, Hayes, \& Paulk, 1997). The appraisal at CMMI level 5 of a vendor software firm may send signals to the client of the former's improved internal mechanisms that may enhance the client's trust in the capabilities of the Indian company (Gopal \& Gao, 2009; Terlaak \& King, 2006). Such an appraisal may result in legitimacy and efficiency gains to a vendor software firm (Gopal \& Gao, 2009). Improved disciplined internal processes of a vendor company allay one of the top concerns of clients regarding the vendor's ability to provide efficient and high-quality services (Gopal \& Gao, 2009). The service quality and operational efficiency of vendor software firms have been listed as the top concerns of U.S. based client companies considering offshoring decisions (Couto, Mani, Lewin, \& Peeters, 2006). 
Hence, CMMI appraisal may play an important role in improving the internal processes in Indian software companies that have distributed project teams placed in multiple project sites and working on different segments of a big software project. It is highly likely that the Indian software firms that have been appraised at CMMI level 5 can effectively signal to the firms of their enhanced capabilities and can engage in increased exports. On the other hand, firms that have not been appraised at CMMI level 5 may not be able to convince client companies that effectively. Indian software firms with CMMI level 5 appraisals, by virtue of possessing disciplined processes, may be in a different league of operations wherein they find themselves competing with multinational IT services companies such as IBM. This may further increase the propensity of firms with CMMI level 5 appraisal to locate in developed countries for market-seeking purpose. Hence, the Indian software firms that CMMI level 5 appraisal will have an increased tendency to locate in developed countries with market-seeking strategies than the firms that do not have the appraisal. However, as the Indian software firms without the CMMI level 5 appraisal are likely to have already high propensities to locate in a developed country with market-seeking strategies, the increased propensities of firms with CMMI level 5 appraisal to locate in a developed country with market-seeking purposes is unlikely to be much higher than the firms without the database. Hence, the effect may not be observable in case of market-seeking strategies of Indian software firms.

On the contrary, the interaction effect is likely to be observable in the case of labor-seeking behaviors of the two set of firms. The CMMI appraisal at the highest level of maturity may give Indian software firms cost competitive advantages to run global delivery centers efficiently even in a developed nation so as to increase the service levels to their clients. Hence the following is proposed.

Hypothesis 4: Among Indian software firms, the relationship between their strategy-type and location choice will be moderated by CMMI level-5 appraisal, such that a firm with appraisal will show more likelihood to locate in a developed country than one without appraisal when its strategy-type is labor-seeking, but not when its strategy-type is market-seeking.

To test these hypotheses, data is hand-collected from Indian software companies on their international location decisions between April 2000 and March, 2009. The next chapter details the data collection procedure. 


\section{CHAPTER VII}

\section{VARIABLES AND DATA COLLECTION}

The extant literature was reviewed in order to understand how other scholars have operationalized the likely dependent, independent and control variables to be used in this dissertation.

1) Dependent variable

The dependent variable in this dissertation is categorical namely developed country (coded 1) and emerging markets (coded 0). Data is collected from the annual reports of the surveyed firms and also from internal web-portal, also called intranet of the company. The data, so collected, is scrutinized and validated by the interviewed managers of each firm. This dissertation combines the IMF and Hoskisson et al. (2000) categorization of countries to divide the countries into the two categories.

2) Independent Variables

Data were collected on four independent variables namely internationalization strategy, whether a firm possessed electronic knowledge sharing database, wage bill per employee, and whether a firm was appraised at CMMI level 5. Each of the independent variables is explained below.

(i) Internationalization Strategy: A literature review was conducted to understand how past studies operationalized the international strategy variable. The summary of the findings of the literature review is given below in Table 3.

Table 3: Variables related to Internationalization Strategies

\begin{tabular}{|l|l|l|}
\hline Authors & Independent Variables & Control Variables \\
\hline Makino et & Labor-seeking, Asset-seeking, Market-seeking & Subsidiary Age (Year of foundation) \\
al. 2002 & (dummy = 1 if motivation present, 0 otherwise) & Entry Mode (dummy =1 for joint- \\
& Data Source: Survey & venture, 0 for wholly-owned \\
& & subsidiary) \\
& & Firm size (number of employees) \\
& & Foreign sales (overseas sales / total \\
& sales) \\
\hline
\end{tabular}




\begin{tabular}{|l|l|l|}
\hline Galan et & Cost factors; & Firm size (sales); \\
al. 2007 & Market factors; & Business sector (services / \\
& $\begin{array}{l}\text { Infrastructure and technological factors; } \\
\text { Political and legal factors; } \\
\text { Social and Cultural factors. } \\
\end{array}$ & \\
Data Source: Survey. & \\
\hline
\end{tabular}

Other studies that have used market-seeking, asset-seeking, and resource-seeking as independent variables are Brouthers et al. (2008), Cuervo-Cazurra (2007), Makino et al. (2007), Sethi et al. (2003), and Song (2002).

Song (2002) uses local sales ratio to operationalize market-seeking versus export-seeking strategies. High local sales ratio indicates market-seeking, whereas low local sales ratio is part of exportseeking strategy. Sethi et al. (2003) use principal component analysis to label market-attractiveness of a country, which includes Gross National Product (GNP) and population of the country. As per CurevoCazurra (2007), firm is market-seeking when its initial operation in a host country is sales, services, repair, or distribution. Makino et al. (2007) use internationalization strategies as independent variables to study the termination of international joint ventures. They operationalize these strategies with help of surveyquestions. Labor-seeking is access to low-cost inputs; market-seeking is following customers and marketexpansion; and strategic asset-seeking is research and development (R\&D). Brouthers et al. (2008) use industries of the firms to divide them into either market-seeking or resource-seeking types.

Based on the above, it may be observed that there are few studies that provide scales to measure the constructs of market-seeking, asset-seeking, and resource-seeking strategies. Although Galan et al. (2007) provides scales to measure the market-factors and cost-factors for internationalization, these scales use location determinants to develop the items.

This dissertation uses categorical variable namely purpose to denote market-seeking and laborseeking strategy. When an Indian software firm located in a host country with a global delivery center, it is used as a proxy for labor-seeking strategy and is coded 0 . On the other hand, if a firm locates in a host 
country with a sales office, it is coded as 1 . There are instances when a company locates in a host country with more than one strategy. For example, a firm may locate in Brazil with both market-seeking and laborseeking strategies. There is, however, never an instance when the firm opens both a sales and global delivery center at the same time in the same location. Hence, each time a firm enters a country where it is already located, the new entry is counted as a new location and its strategy is coded accordingly.

Besides internationalization strategy, data were also collected on the following resources of Indian softweare firms. These resources constitute other independent variables, besides internationalization strategy in the dissertation.

(ii) Knowledge-management by the Indian software vendor firm: The knowledge management by the software company enhances the knowledge about the client and the projects. The existing knowledge stock helps bid in a cost-effective manner for similar projects announced by other companies and new projects announced by the existing clients. The variable namely "whether or not a company possesses knowledgemanagement software in each of the 9 years of the study period" has been used as a proxy for Knowledgemanagement by the Indian software vendor firm. It is a dichotomous variable, coded 0 in the year when the firm did not have the electronic database and coded 1 in the year in which the firm had such a database.

(iii) Internal processes of the software vendor firm to deliver quality goods to the client: The steps undertaken by Indian software firms to streamline their internal processes may have helped these companies become successful. The better the internal processes, the better is likely to be the quality of the products delivered to the client companies in a cost-effective manner. A variable namely "whether or not a company possesses CMMI-level 5 (Capability Maturity Mode Integration level 5) has been used as proxy to measure the level of internal processes of the software vendor firm to deliver quality goods to the client. It is a dichotomous variable, coded 0 in the year when the firm did not have the appraisal and coded 1 in the year in which the firm had the appraisal.

As per the industry experts, the state-of-the-art hardware and software platforms used by Indian software firms may help Indian software companies deliver cost-efficient services and products to their clients. However, a variable that may act as a proxy for the status of technological sophistication and 
recency of the hardware and software platforms used by Indian software firms could not be collected in the dataset that.

(iv) Low cost but qualified human talent with the software vendor firm: The cost and quality of the human talent possessed by the software firm is one of the dimensions of the construct called process-related resource. The low cost skilled manpower has been long recognized to result into the international growth of Indian software firms (Pradhan, 2007). A variable namely "wage bill per employee" has been used as a proxy for Low cost but qualified human talent with the software vendor firm. This is calculated by dividing the total wage bill of the company in a year by its total number of employees in that year.

3) Control variables

(i) Variables related to Macroeconomic Determinants: In Table 4 below, some studies are listed that have studied the impact of macroeconomic variables on location choice. The macroeconomic variables are used as control variables in the dissertation.

Table 4: Macroeconomic Determinants.

\begin{tabular}{|c|c|}
\hline $\begin{array}{l}\text { Authors and } \\
\text { Year }\end{array}$ & Independent Variables \\
\hline $\begin{array}{l}\text { Li \& } \\
\text { Guisinger, } \\
1992\end{array}$ & $\begin{array}{l}\text { Market size (GDP) } \\
\text { Cultural distance: K\&S } 1988 \text { method using scores from Hofstede's } 1980 \\
\text { Openness index } \\
\text { Oligopolistic reaction: number of other service firms / total number of service } \\
\text { firms } \\
\text { Growth in firm size: annual growth rate in sales } \\
\text { Home country business presence in a host country: book value of FDI in host } \\
\text { country } \\
\text { Data Source: archival }\end{array}$ \\
\hline $\begin{array}{l}\text { Woodward } \\
\text { \& Rolfe } \\
1993\end{array}$ & $\begin{array}{l}\text { Level of infrastructure development: Per capita GNP } \\
\text { Wage rate: Log of Adjusted } 1985 \text { hourly wage, including fringe benefits, for } \\
\text { unskilled operators in each country in } 1985 \text {. }\end{array}$ \\
\hline
\end{tabular}




\begin{tabular}{|c|c|}
\hline & $\begin{array}{l}\text { Political stability: } 1=\text { most stable; } 0=\text { least stable } \\
\text { Income tax incentives: } 1=\text { more than } 10 \text { years; } 0=\text { less than or equal to } 10 \\
\text { years, 1984). } \\
\text { Free trade Zones: Log of area in acres } \\
\text { Profit repatriation restrictions: } 1=\text { most restrictive; } 0=\text { less restrictive, } 1984 \\
\text { Exchange rate devaluation: Log of annual growth rate } 1974-83 \\
\text { Land area: Log of area in sq kilometers } \\
\text { Manufacturing concentration: proportion of total labor force in manufacturing } \\
\text { in } 1984 \\
\text { Inflation rate: Log of annual growth rate } 1974-83 \\
\text { Transport costs: Log of transportation cost as proportion of trade } \\
\text { Unionization rate: Log of proportion of total labor force. } \\
\text { Data Source: archival }\end{array}$ \\
\hline $\begin{array}{l}\text { Loree \& } \\
\text { Guisinger } \\
1995\end{array}$ & $\begin{array}{l}\text { Performance requirements: survey-questions } \\
\text { Investment incentives: survey-questions } \\
\text { Political stability: index of political, financial and economic risk } \\
\text { Cultural distance: Kogut \& Singh } 1988 \text { index } \\
\text { Income level in host country: Log of GDP per capita } \\
\text { Infrastructure: } 22 \text { variables factor analyzed to obtain } 2 \text { factors namely } \\
\text { communication and transportation } \\
\text { Wages: Log of average salary in host country } \\
\text { Developed country dummy: } 1,0 \text { otherwise } \\
\text { Data Source: Survey and archival }\end{array}$ \\
\hline $\begin{array}{l}\text { Grosse \& } \\
\text { Trevino, } \\
1996\end{array}$ & $\begin{array}{l}\text { Bilateral trade: export and import to and from the USA Market-size of home } \\
\text { country: GDP } \\
\text { Per-capita income: GNP / population }\end{array}$ \\
\hline
\end{tabular}




\begin{tabular}{|c|c|}
\hline & $\begin{array}{l}\text { Political risk: Source: Political risk services "Investment risk" ratings } \\
\text { Geographic distance: miles from home country capital to the host city. } \\
\text { Cultural distance: Gross \& Goldberg index with scores from Hofstede. } \\
\text { Relative cost of borrowing: home country prime rate / prime rate in the USA } \\
\text { Exchange rate: level of bilateral exchange rate at the year end. } \\
\text { Relative rate of return: average stock market share price index } \\
\text { Data Source: Archival }\end{array}$ \\
\hline $\begin{array}{l}\text { Zhao \& Zhu } \\
2000\end{array}$ & $\begin{array}{l}\text { Market potential: GNP per capita; CFTR (ratio of the product sales income to } \\
\text { the average balance of circulating fund). } \\
\text { Export: export value as \% of GDP } \\
\text { Efficiency: profit ratio: after-tax profit to total sales } \\
\text { Cost advantage: labor cost (average wage of a city), rental cost } \\
\text { Productivity level: net value added per employee } \\
\text { Technological level: ratio of technology development expenditure to GDP. } \\
\text { Infrastructure: index with } 3 \text { elements: transportation route (road space) per sq } \\
\text { kilometer; number of post office per capita; number of telephone lines per } \\
\text { capita. } \\
\text { Data Source: Archival }\end{array}$ \\
\hline
\end{tabular}

The dissertation uses the following variables to control for various macroeconomic variables.

Logofgdp: This variable is the natural log of GDP of the host country in current US Dollar for the year in which an Indian software firm chose the host country as its location. The source of the data is world development indicators by the World Bank. There were no missing data for this variable.

Logoftax: This variable is the natural log of highest marginal corporate tax rate in percentage in the host country for the year in which an Indian software firm chose the host country as its location. The source of data is world development indicators by the World Bank. The missing data were treated with help of the KPMG's Corporate and Indirect Tax Rate Survey 2008 available at 
http://www.kpmg.com/SiteCollectionDocuments/Corporate-and-Indirect-Tax-Rate-Survey-2008v2.pdf. This website was accessed on August 5, 2009.

Logofinflation: This variable is the natural log of percentage of annual inflation in consumer prices in the host country for the year in which an Indian software firm chose the host country as its location. The source of data is world development indicators by the World Bank. The data was transformed by adding integer 6 to each number so as to convert all data pertaining to this variable into a positive integer. The natural log was calculated on the transformed data. There were no missing data for this variable.

ICT Development Index: This variable is an index of the development of internet and telecommunication infrastructure of the host country in the year in which an Indian software firm chose to locate there. The data were collected form the publication by the International Telecommunication Union entitled "Measuring the Information Society, 2009".

Logofpopulation: This variable is the natural $\log$ of the total population of the host country for the year in which an Indian software firm chose to locate in the host country. The source of data is world development indicators by the World Bank.

Logoffdistk: This is the natural log of the FDI stock in the host country in US Dollar at current prices for the year in which an Indian software firm chose to locate in the host country. The source of the data was the UNCTAD. The data were lagged by 1 year. The missing value were treated by multiplying the base value in the year preceding the missing year by the simple average of the increase in FDI stock in preceding three years for the particular host country.

ExchangeRate: This variable indicates the fluctuation in the exchange rate of the local currency of the host country against the US Dollar compared to its exchange rate in the preceding year. A number less than 1 indicates that the local currency depreciated against US Dollar in the year of interest and a number greater than 1 indicates that the local currency appreciated against US Dollar in the year of interest. A number equal to 1 indicates that the local currency did not change against the US Dollar. The extent of decrease or increase from one indicates the extent of fluctuation of the local currency against the US 
Dollar. The sources of data are International Monetary Fund (IMF) and the US Department of Commerce. The data were lagged by a year.

Logoflabor: The variable is the natural log of the ratio of the labor rates between the capital city of the host country and India (the labor rates in city of Mumbai). The data source is Prices \& Earnings report compiled by the Union Bank of Switzerland (UBS). The data are lagged by 1 year. The Prices \& Earnings reports are available for years 2003, 2005, 2006, 2008 and 2009. The missing data were treated by imputing the same ratio number as was available for the closest year to the missing year. The labor rates may change from year to year. However, the method of imputing the number available for the closest year to treat a missing value was deemed appropriate.

HDI: This variable indicates the index of human development as published in the various volumes of the Human Development Report compiled for the United Nations Development Program (UNDP). The index assigns different countries a score out of 1 . The higher the score assigned to a nation, the better the human development in that nation is. The missing data were treated by imputing the same index number as was available for the closest year to the missing year for the host country. As the human development index of a host country is not envisaged to undergo significant changes in a shorter time frame, the method of imputing the number available for the closest year to treat a missing value was deemed appropriate. The data were lagged by 1 year.

(ii) Variables related to Institutions: Table 5 given below details some studies that have studied the impact of institutions on location decisions of firms. The proxy variable for institution is used as a control variable in the dissertation.

Table 5: Institutions

\begin{tabular}{|c|c|c|}
\hline $\begin{array}{l}\text { Authors } \\
\text { and Year }\end{array}$ & Independent Variables & Control Variables \\
\hline $\begin{array}{l}\text { Globerman } \\
\text { \& Shapiro } \\
2003\end{array}$ & $\begin{array}{l}\text { Governance infrastructure index (GII): } \\
\text { from Kaufmann, Kraay, and Zoido- } \\
\text { Lobaton (1999) } \\
\text { Legal systems (common or civil): by }\end{array}$ & $\begin{array}{l}\text { Host country size: Real GDP } \\
\text { Human Development Index } \\
\text { If the country uses a fixed } \\
\text { exchange rate: Dummy =1 }\end{array}$ \\
\hline
\end{tabular}




\begin{tabular}{|c|c|c|}
\hline & $\begin{array}{l}\text { La Porta et al. 1999, and from } \\
\text { university of Ottawa Faculty of Law } \\
\text { (used as substitutes of GII). } \\
\text { Index of Economic Freedom } \\
\text { Data source: Archival }\end{array}$ & $\begin{array}{l}\text { Exchange rate: ratio of end period } \\
\text { trade-weighted exchange rate to } \\
\text { average for preceding } 2 \text { years in } \\
\text { terms of USD. } \\
\text { NAFTA effects: dummy (=1) for } \\
\text { Canada and Mexico } \\
\text { Omitted variables: Wage rate, tax } \\
\text { rates, openness of the country } \\
\text { (measured as (imports }+ \text { exports) / } \\
\text { GDP, Cultural distance: dummy } \\
\text { variable (=1) for English. }\end{array}$ \\
\hline $\begin{array}{l}\text { Flores \& } \\
\text { Aguilera, } \\
2007\end{array}$ & $\begin{array}{l}\text { Market affluence: GDP in billions } \\
\text { Market magnitude: Population } \\
\text { Infrastructure: Total number of phone } \\
\text { lines } \\
\text { Wage level: average wages received } \\
\text { by manufacturing workers who work } \\
40 \text { hrs per week } \\
\text { Political institutions: } 1 \text { when a country } \\
\text { is democracy, } 0 \text { otherwise. Legal } \\
\text { Systems: } 1 \text { when same legal system, } 0 \\
\text { otherwise } \\
\text { Cultural distance: modified K\&S } \\
\text { (1988) index using Hofstede (1983), } \\
\text { controlling for language, geographic } \\
\text { size and company size }\end{array}$ & $\begin{array}{l}\text { Firm size: total no. of employees } \\
\text { Firm Performance: return to } \\
\text { investors in last } 10 \text { years; } \\
\text { Firm industrial sector: 2-digit SIC } \\
\text { coding scheme } \\
\text { Official language: dummy (1 if } \\
\text { English, } 0 \text { otherwise) } \\
\text { Geographic distance: between } \\
\text { capital cities of home and host } \\
\text { countries } \\
\text { Regional location: }(19 \text { UN } \\
\text { regional categories), dummy } 1 \text { if } \\
\text { country is in that region, } 0 \\
\text { otherwise); } 1 \text { if economically developed, } 0 \\
\text { Economic development: dummy }\end{array}$ \\
\hline
\end{tabular}




\begin{tabular}{|c|c|c|}
\hline & $\begin{array}{l}\text { Level of trust in a society } \\
\text { Data Source: Archival }\end{array}$ & otherwise). \\
\hline $\begin{array}{l}\text { Cuervo- } \\
\text { Cazurra, } \\
2008\end{array}$ & $\begin{array}{l}\text { Pervasive corruption } \\
\text { Arbitrary corruption (using a method } \\
\text { by Uhlenbruck et al. 2006). } \\
\text { Data Source: Archival }\end{array}$ & $\begin{array}{l}\text { Country size: GDP, } \\
\text { Population } \\
\text { Host country inflation } \\
\text { Geographic distance: natural log } \\
\text { of greater circle distance between } \\
\text { the home and host country centers } \\
\text { in miles Landlocked or Common } \\
\text { border: Common Language } \\
\text { Common Colonial histories } \\
\text { FDI limitations }\end{array}$ \\
\hline $\begin{array}{l}\text { Brouthers } \\
\text { et al., } 2008\end{array}$ & $\begin{array}{l}\text { Market attractiveness for market- } \\
\text { seeking FDI: GDP per capita } \\
\text { Market attractiveness for labor-seeking } \\
\text { FDI: average monthly wage in } \\
\text { manufacturing } \\
\text { Market attractiveness for raw-material } \\
\text { seeking FDI: level of domestic energy } \\
\text { production } \\
\text { Corruption: rating from } 0-10 \text {. } \\
\text { Data Source: Archival }\end{array}$ & $\begin{array}{l}\text { International orientation of a } \\
\text { country: Trade / GDP } \\
\text { Ratio of Government consumption } \\
\text { to GDP }\end{array}$ \\
\hline
\end{tabular}

Based on the above, it may be noted that Kaufmann et. al's scale to measure the institutional development of a country suits this dissertation. The scale developed by Kaufmann et. al (1999) includes (i) voice, political freedom and civil liberties; (2) political instability, terrorism and violence; (3) the rule of law, crime, contract enforcement and property law; (4) level of graft and corruption in public and private 
institutions; (5) extent of regulation and market openness; (6) measure of government effectiveness and efficiency. The scale provides a comprehensive coverage of the institution-related location determinants which may impact the location decision of a firm. Other recent study that has used Kaufmann et. al's (1999) scale to measure the governance structure of a country is by Bhardwaj, Dietz, and Beamish (2007).

There are other scales developed by scholars such as Henisz (2000) and La Porta, Lopez-deSilanes, Shleifer, and Vishny (1998). But the foci of these scales are narrower. For example, Henisz (2000) focus is the level of political hazard in a country; whereas La Porta et. al (1998) finds the type of legal system in a country. Delios and Beamish (2001) measure institutional environment of a country with help of (i) extent of its political and economic risks, (ii) extent of its restrictions on foreign ownership, and (iii) extent of intellectual property protection in the country. Steensma, Tihanyi, Lyles, and Dhanaraj (2005) use regulatory quality, liberalization index, corruption index, government stability, government transparency ranking, and private sector as percent of GDP to measure the institutional development of transition economies.

Other studies such as Globerman and Shapiro (2003) have used the index of economic freedom compiled by the Heritage Foundation. The index is updated for year 2009. Hence, it is used as a proxy to denote institutions in various host countries. The variable is denoted by "institution". This variable is an index of the level of institutional development of a host country for the year in which an Indian software firm chose to locate there. The missing data were treated by imputing the same index number as was available for the closest year to the missing year for the host country. As the institutions are not envisaged to undergo significant changes in a shorter time frame, the method of imputing the number available for the closest year to treat a missing value was deemed appropriate.

(iii) Variables related to Cultural Distance: Table 6 below gives a summary of how other scholarly studies in past have operationalized cultural distance.

Table 6: Cultural Distance

\begin{tabular}{|l|l|l|}
\hline Authors and & Independent & Control Variables \\
Year & Variables & \\
\hline Benito \& & Cultural Distance: & - Export share of the parent firm \\
\hline
\end{tabular}




\begin{tabular}{|l|l|l|}
\hline Gripsrud 1992 & $\begin{array}{l}\text { Kogut \& Singh } \\
\text { (1988) index }\end{array}$ & $\begin{array}{l}\text { - Sales of the parent firm } \\
\text { - Mode of entry (greenfield / acquisition) } \\
\end{array}$ \\
& \begin{tabular}{l} 
- Ownership \% of FDI \\
\hline
\end{tabular} \\
\hline
\end{tabular}

Besides the above paper, many other scholars in the location literature have used cultural distance as a control variable and it may be observed from these studies that the Kogut and Singh (1988) measure of cultural distance is widely used to measure the cultural distance between the home and host countries (For example, Berkema et al., 1996; Ellis, 2008; Tsang \& Yip, 2007). Some recent studies have included other variables along with the cultural distance index to overcome the criticism of using the Hofstede's scores in measuring the cultural distance (Shenkar, 2001). These variables are language and time zone.

Recently, Dow and Karunaratna (2006) provide a comprehensive measure of perceived psychic distance between home and host countries. Their measurement of psychic distance includes differences in culture (Kogut \& Singh, 1988), language, political system, religion, industrial development (GDP per capita, passenger car per 1000, energy consumption per capita, population living in urban cities, manufacturing as $\%$ of GDP, telephone as $\%$ of GDP), education, time zones.

As this dissertation measures the levels of institutional and infrastructure development of a host country with help of other indices, use of psychic distance as measured by Dow and Karunaratna (2006) might result in multicollinearity in the dataset as Dow and Karunaratna (2006) include industrial development and political systems as part of their index. To avoid multicollinearity, this dissertation includes cultural distance as measured by the Kogut and Singh (1988) index using Hofstede's score (2001). At the same time, this dissertation controls for variables such as language and time zone in line with suggestions made by Shenkar (2001). The following measures are used as proxy for cultural distance between India and host countries.

Time Diff: This variable is the absolute difference in time in hours between the capital city of the host country and the city of the headquarters of the Indian software firm that chose to locate in the host country of interest. The source of data is the World Clock. 
Isenglishspoken: This is a dichotomous variable and takes the value equal to 2, if English is spoken in a country, otherwise it assumes a value of 1 . The source of the data is the CIA Fact Book.

CulturalDistance: This variable indicates the cultural distance between the host country and India.

The Kogut \& Singh (1988) measure of cultural distance was used in the dissertation.

(iv) Variables related to Geographic and Economic distance: In extant literature, geographic distance is measured by the physical distance between capital cities or some focal cities of the home and host countries (Erramilli et al., 1999). This dissertation operationalizes geographic distance in the same manner. The variable is called LogofGeoDistance and is the natural log of the geographic distance in nautical miles between the capital city of the host country and the city of the headquarters of the Indian software firm that chose to locate in the host country of interest. The source of data is the World Atlas.

Economic distance is used by Tsang and Yip (2007) as a location determinant affecting the location decisions of firms. They operationalize economic distance as difference in natural logs of real GDP per capita of Singapore and the host country. As GDP per capita is included as one of the variables in this dissertation to reflect the market size of a host country, economic distance is not included separately as a variable in this dissertation.

(v) Variables related to International Experience and Top Management Characteristics (TMT): Table 7 below summarizes how past studies have operationalized the variables related to international experience and top management characteristics.

Table 7: International Experience and TMT

\begin{tabular}{|c|c|c|}
\hline $\begin{array}{l}\text { Authors and } \\
\text { Year }\end{array}$ & Independent Variables & Control Variables \\
\hline $\begin{array}{l}\text { Sambharya, } \\
1996\end{array}$ & $\begin{array}{l}\text { International experience in years; proportion } \\
\text { of top managers with international } \\
\text { experience; } \\
\text { homogeneity of international experience. }\end{array}$ & $\begin{array}{l}\text { Firm size (Sales) } \\
\text { TMT size }\end{array}$ \\
\hline $\begin{array}{l}\text { Tihanyi et } \\
\text { al., } 2000\end{array}$ & $\begin{array}{l}\text { Age (in years); } \\
\text { Team tenure; }\end{array}$ & $\begin{array}{l}\text { Firm profitability (Prior ROA in } 3 \\
\text { years); }\end{array}$ \\
\hline
\end{tabular}




\begin{tabular}{|l|l|l|}
\hline & $\begin{array}{l}\text { Elite education (categorical variable); } \\
\text { International experience (through } \quad \text { TMT team size. } \\
\text { assignment or education); } \\
\text { Educational background; } \\
\text { Functional background (seven categories). }\end{array}$ & \\
\hline
\end{tabular}

The data pertaining to top management international experience and tenure could only be collected for the year 2009 in the dissertation. As other time variant variables in the dissertation have been collected for each time period, it was considered better to not control for TMT experience and its tenure in the dissertation. In the model, there are other control variables such as international experience and firm age of the firm that may overcome, to some extent, the lack of the TMT variables in the model.

(vi) Variables related to Agglomeration: Rose and Ito (2008) operationalize oligopolistic reaction as number of rivals, aside from the focal firm, with a subsidiary in the host country prior to the focal firm's entry. A measure of imitation as used by Filatotchev et al. (2007) is the cumulative Indian FDI in the host country. However, the lack of reliable data denoting the number of already operating Indian firms or yearwise cumulative Indian FDI in each of the host country precludes this dissertation from controlling for agglomeration factor. Agglomeration becomes an important variable if firms internationalize with assetseeking strategy. Since, Indian software companies are not internationalizing with asset-seeking strategy, inability to control for agglomeration is not likely to have impact on the validity of the statistical results obtained in the dissertation.

A list of dependent, independent, firm-specific and host country-specific control variables used in this dissertation and their sources are given in the following tables.

Table 8: Data-source for Dependent and Independent Variables

\begin{tabular}{|l|l|}
\hline Variable Name & Source of data \\
\hline Location (Dependent Variable) & Firm annual reports and intranet \\
\hline Purpose (Independent variable) & Firm annual reports and intranet \\
\hline CMMI (Independent variable) & Firm annual reports, firm archives such as presentations, \\
\hline
\end{tabular}




\begin{tabular}{|l|l|}
\hline & $\begin{array}{l}\text { newspaper items, firm websites, intranet, stock exchange } \\
\text { archives }\end{array}$ \\
\hline KMSW & $\begin{array}{l}\text { Firm annual reports, firm archives such as presentations, } \\
\text { newspaper items, firm websites, intranet, stock exchange } \\
\text { archives }\end{array}$ \\
\hline Wage Bill per employee & Annual report \\
\hline
\end{tabular}

Table 9: Data-source for Firm-specific Control Variables

\begin{tabular}{|l|l|}
\hline Variable Name & Source of data \\
\hline Reentry & Self-compiled based on the data on location. \\
\hline EntryMode & Firm annual reports and intranet \\
\hline LogofSales & Firm annual reports \\
\hline Profit & Firm annual reports \\
\hline ROS & Firm annual reports \\
\hline Cash & Firm annual reports \\
\hline Logtotalempl & $\begin{array}{l}\text { Firm annual reports, firm archives such as presentations, newspaper } \\
\text { items, firm websites, intranet, stock exchange archives }\end{array}$ \\
\hline FirmAge & Firm annual report \\
\hline BusinessGroup & Annual report \\
\hline Indiagdc & Firm annual reports, firm archives such as presentations, newspaper \\
& items, firm websites, intranet, stock exchange archives \\
\hline Internationalexp & Annual report \\
\hline
\end{tabular}

Table 10: Data-source for Host Country-specific Control Variables

\begin{tabular}{|l|l|}
\hline Variable Name & Source of data \\
\hline Logofgdp & World Bank \\
\hline
\end{tabular}




\begin{tabular}{|l|l|}
\hline Logoftax & World Bank, KPMG's Corporate and Indirect Tax Rate Survey 2008 \\
\hline Logofinflation & World Bank \\
\hline ICT & International Telecommunication Union \\
\hline Logofpopulation & World Bank \\
\hline Institution & Heritage Foundation \\
\hline LogofGeoDistance & World Atlas \\
\hline TimeDiff & World Clock \\
\hline HDI & UNDP \\
\hline Isenglishspoken & CIA Fact Book \\
\hline Logoffdistk & UNCTAD \\
\hline ExchangeRate & IMF and US Department of Commerce \\
\hline Logoflabor & Prices \& Earnings report by the Union Bank of Switzerland \\
\hline CulturalDistance & Hofstede's scores \\
\hline
\end{tabular}

\section{Data Collection}

In the summer of 2009, the top 32 publicly-listed Indian software companies were contacted to hand-collect data to study their international location choices made by them between April 2000 and March 2009. The data were compiled from several publicly available sources such as company websites, news items, initial public offer documents of the firms, annual reports, presentations to media and investors, and also from firms' internal archival documents and their intranets. Data-sources such as the ones compiled by Ministry of Finance, Government of India are inadequate to analyze the research questions outlined in the dissertation as these data-sources do not provide much information on foreign subsidiaries of Indian firms (Pradhan, 2007), and it necessitated the compilation of the dataset.

The first year of data collection is taken as 2000 as significant policy changes by the government of India resulted in rapid outward FDI since then (UNCTAD, 2004). The variables pertaining to the firms were collected at two levels. Some variables could be collected at the level of each location decision made by the firm within a year, so these variables change with each location decision made by the firm. The 
remaining variables could be collected at the level of each year of the study. Consequently, these variables change only year to year and remain invariant for all the location decisions made within a year by a firm. The ideal scenario would have been the collection of all time-variant data at the level of location decision. However, paucity of the firm records at the level of location decision for all variables restricted the collection of data at two levels namely location decision and year level. The list of variables and the level at which these variables were collected are tabulated below. Table 11 below also gives a brief description of the variables and lists if a variable is continuous or dichotomous.

Table 11: Level of Firm-specific Data Collection

\begin{tabular}{|c|c|c|c|}
\hline Variable Name & $\begin{array}{l}\text { Level at which the } \\
\text { data collected }\end{array}$ & Variable Description & $\begin{array}{l}\text { Continuous or } \\
\text { Dichotomous }\end{array}$ \\
\hline $\begin{array}{l}\text { Location (Dependent } \\
\text { variable) }\end{array}$ & Location decision & $\begin{array}{l}\text { Name of the country where } \\
\text { the firm located }\end{array}$ & $\begin{array}{l}\text { Dichotomous: } 1 \text { for } \\
\text { developed country and } \\
0 \text { for emerging market }\end{array}$ \\
\hline $\begin{array}{l}\text { Purpose (Independent } \\
\text { variable) }\end{array}$ & Location decision & Strategy of the firm & $\begin{array}{l}\text { Dichotomous: } 1 \text { for } \\
\text { market-seeking and } 0 \\
\text { for labor-seeking }\end{array}$ \\
\hline $\begin{array}{l}\text { CMMI (Independent } \\
\text { variable) }\end{array}$ & Yearly level & $\begin{array}{l}\text { If the firm possessed CMMI } \\
\text { level } 5 \text { appraisal at the end } \\
\text { of each year }\end{array}$ & $\begin{array}{l}\text { Dichotomous: } 1 \text { if yes, } \\
0 \text { if no. }\end{array}$ \\
\hline $\begin{array}{l}\text { KMSW (Independent } \\
\text { variable) }\end{array}$ & Yearly level & $\begin{array}{l}\text { If the firm installed a } \\
\text { knowledge management } \\
\text { software at the end of each } \\
\text { year }\end{array}$ & $\begin{array}{l}\text { Dichotomous: } 1 \text { if yes, } \\
0 \text { if no. }\end{array}$ \\
\hline $\begin{array}{l}\text { WageBillperemployee } \\
\text { (Independent variable) }\end{array}$ & Yearly level & $\begin{array}{l}\text { Total wage bill divided by } \\
\text { total employees }\end{array}$ & Continuous \\
\hline Reentry & Location decision & $\begin{array}{l}\text { Whether the firm already } \\
\text { has presence in the country }\end{array}$ & $\begin{array}{l}\text { Dichotomous: } 1 \text { if } \\
\text { already present, } 0 \text { if not }\end{array}$ \\
\hline
\end{tabular}




\begin{tabular}{|c|c|c|c|}
\hline EntryMode & Location decision & $\begin{array}{l}\text { The entry mode for the } \\
\text { location decision }\end{array}$ & $\begin{array}{l}\text { Dichotomous: } 1 \text { if } \\
\text { wholly-owned } \\
\text { subsidiary, } 0 \text { if not }\end{array}$ \\
\hline LogofSales & Yearly level & $\begin{array}{l}\text { Natural log of the revenue } \\
\text { of the firm in each year }\end{array}$ & Continuous \\
\hline Profit & Yearly level & $\begin{array}{l}\text { Profit after tax of the firm in } \\
\text { each year }\end{array}$ & Continuous \\
\hline ROS & Yearly level & $\begin{array}{l}\text { Net Profit Margin of the } \\
\text { firm in each year }\end{array}$ & Continuous \\
\hline Cash & Yearly level & $\begin{array}{l}\text { Net Cash at the end of each } \\
\text { year }\end{array}$ & Continuous \\
\hline Logtotalempl & Yearly level & $\begin{array}{l}\text { Natural log of total } \\
\text { employees at the end of } \\
\text { each year }\end{array}$ & Continuous \\
\hline FirmAge & Yearly level & $\begin{array}{l}\text { The number of years } \\
\text { elapsed since the year of } \\
\text { firm incorporation }\end{array}$ & Continuous \\
\hline BusinessGroup & Firm level & $\begin{array}{l}\text { If the firm is affiliated with } \\
\text { a business group }\end{array}$ & $\begin{array}{l}\text { Dichotomous: } 1 \text { if yes, } \\
0 \text { if no. }\end{array}$ \\
\hline Indiagdc & Yearly level & $\begin{array}{l}\text { Number of Indian cities in } \\
\text { which the firm had a Global } \\
\text { Delivery Center at the end } \\
\text { of each year }\end{array}$ & Continuous \\
\hline Internationalexp & Yearly level & $\begin{array}{l}\text { Years elapsed since the first } \\
\text { year of internationalization }\end{array}$ & Continuous \\
\hline
\end{tabular}


The top 32 publicly listed Indian software firms from which the data is collected have made 650 international location choices in 67 different countries since April 2000 till March 2009. There are 110 publicly listed Indian software companies as on June, 2009, making the sample $29 \%$ of the publicly listed IT and software organizations in India. NASSCOM, the industry association of Indian software companies, categorizes these companies as Tier-I and Tier-II software companies. The top 10 Indian software organizations comprise tier-I and the remaining companies form tier-II of the NASSCOM classifications. The data has all tier-I companies and 22 tier-II companies. According to Gopal \& Gao (2009), Dataquest magazine in 2005 reports that Indian software exports are highly concentrated with the top 5 firms accounting for $30 \%$ while the top 20 firms account for $53 \%$ of the total software exports from India. Another study by Pradhan (2007) mentions that there were 165 Indian information and software technology multinational companies in year 2006 and the top 60 firms among these 165 firms accounted for $72.6 \%$ of the total overseas investments by these companies. Thus, a high concentration of exports and international location decisions in the Indian software industry turns the small number of 32 firms to represent adequately the location decisions made by Indian software companies, though it forms $19.4 \%$ of the 165 information and software technology companies that are reported to have established operations overseas. It has been recognized that data collection poses problems in the context of emerging economies (Hoskisson et. al, 2000). Given the scenario, it is likely that the sample may be biased towards the more active software firms.

The next step in the data collection process was to understand that it is the process-related resources that have assisted Indian software companies go international more than any other resources. To accomplish this, two employees working at the rank of General Manager or above were contacted in each of the 32 software firms at two different time periods and were separately administered a short semistructured interview. Many of the contacted managers were part of the top management team of the companies such as head of human-resources, finance, or marketing departments, or executive directors, CEOs or promoters of the companies. These employees were given a list of the following six resources.

- Non-market resources

- Ethnic relational resources 
- Business relational resources

- Process-related resources

- Market knowledge resources

- Natural asset based resources

The meaning of each of the resources was explained to them. They were, then, asked to rate each of the resources on a scale of 1-5 (where 1 meant not at all helped and 5 meant helped the most in internationalization) if that particular resource helped their firm achieve its present extent of international geographical expansion. The data analysis suggests that it is the process-related resources that have helped Indian software companies go international more than any other resource. Out of the 64 interviewed managers, $81.25 \%$ (52 in number) of them rate process-related resources as the most important resource that boosted their firms' internationalization effort.

Host country related variables

There are 67 countries in which the 32 sampled Indian software firms have located between April 2000 and March 2009 for market-seeking and labor-seeking purposes. These countries are a mix of developed countries and emerging markets. The control data for each of the host country was collected at the level of the location decision as given in the following Table 12.

Table 12: Level of Host Country-specific Data Collection

\begin{tabular}{|l|l|l|l|}
\hline Variable Name & $\begin{array}{l}\text { Level at which the } \\
\text { data collected }\end{array}$ & Variable Description & $\begin{array}{l}\text { Continuous or } \\
\text { Dichotomous }\end{array}$ \\
\hline Logofgdp & Location decision & $\begin{array}{l}\text { Natural log of GDP of the } \\
\text { country in the year in which a } \\
\text { firm located there }\end{array}$ & Continuous \\
\hline Logoftax & Location decision & $\begin{array}{l}\text { Natural log of tax rate of the } \\
\text { country in the year in which a } \\
\text { firm located there }\end{array}$ & Continuous \\
\hline Logofinflation & Location decision & Natural log of annual inflation & Continuous \\
& & rate of the country in the year in & \\
\hline
\end{tabular}




\begin{tabular}{|c|c|c|c|}
\hline & & which a firm located there & \\
\hline ICT & Location decision & $\begin{array}{l}\text { An index of development of } \\
\text { Information and } \\
\text { telecommunication } \\
\text { infrastructure in the country in } \\
\text { the year in which a firm located } \\
\text { there }\end{array}$ & Continuous \\
\hline Logofpopulation & Location decision & $\begin{array}{l}\text { Natural log of population of the } \\
\text { country in the year in which a } \\
\text { firm located there }\end{array}$ & Continuous \\
\hline Institution & Location decision & $\begin{array}{l}\text { Institutional score out of } 100 \text { of } \\
\text { the country in the year in which } \\
\text { a firm located there }\end{array}$ & Continuous \\
\hline LogofGeoDistance & Location decision & $\begin{array}{l}\text { Natural log of geographic } \\
\text { distance of the country in which } \\
\text { a firm located from India }\end{array}$ & Continuous \\
\hline TimeDiff & Location decision & $\begin{array}{l}\text { Time difference in hours } \\
\text { between the country of location } \\
\text { and India }\end{array}$ & Continuous \\
\hline HDI & Location decision & $\begin{array}{l}\text { Human Development Index } \\
\text { score (out of 1) of the country } \\
\text { in the year in which a firm } \\
\text { located there }\end{array}$ & Continuous \\
\hline Isenglishspoken & Location decision & $\begin{array}{l}\text { If English is spoken or not in } \\
\text { the country in which a firm } \\
\text { located }\end{array}$ & $\begin{array}{l}\text { Dichotomous: } 1 \text { for } \\
\text { yes, } 0 \text { for no. }\end{array}$ \\
\hline Logoffdistk & Location decision & Natural log of FDI stock of the & Continuous \\
\hline
\end{tabular}




\begin{tabular}{|c|c|c|c|}
\hline & & $\begin{array}{l}\text { country in the year in which a } \\
\text { firm located there }\end{array}$ & \\
\hline ExchangeRate & Location decision & $\begin{array}{l}\text { Ratio of exchange rates of local } \\
\text { currency of the host country to } \\
\text { US dollar in the year in which a } \\
\text { firm located in the host country }\end{array}$ & Continuous \\
\hline Logoflabor & Location decision & $\begin{array}{l}\text { Natural log of ratio of labor } \\
\text { rates of the host country to } \\
\text { those in India in the year in } \\
\text { which a firm located there }\end{array}$ & Continuous \\
\hline CulturalDistance & Location decision & $\begin{array}{l}\text { Cultural Distance between the } \\
\text { host country and India }\end{array}$ & Continuous \\
\hline
\end{tabular}

In the following chapter, the statistical analysis is applied on these variables with help of hierarchical linear modeling or random coefficient growth modeling using software HLM 6.2. 


\section{CHAPTER VIII}

\section{METHODOLOGY, RESULT, AND DISCUSSION}

Hierarchical Linear Modeling (HLM) is an appropriate methodology to analyze a hierarchical data, longitudinal data, and test hypotheses about how variables measured at one level affect relations occurring at another level (Raudenbush \& Bryk, 2002). The data collected for the dissertation has a hierarchical structure as the location decisions made by the 32 sampled firms are nested within each firm and each of these firms make several international location decisions over the period of the data collection. Thus, a location decision made by a firm may not be independent of the other decisions made by the same firm in previous years as multiple observations from the same source tend to be correlated (Bliese \& Ployhart, 2002). Further, the resulting design is unbalanced as the number of location decisions made by a firm may differ from those made by other firms. For a nested dataset such as this with dichotomous dependent variable, logistic regression is not an appropriate methodology as the assumption of independent observations is violated in this data and hence estimates are likely to be biased.

Application of non-multilevel analyses such as logistic regression in the scholarly area of entry mode research which is a multilevel research question has been recently criticized by Arregle et al (2006) and they suggested the use of HLM to address entry mode related research questions. Ignoring the multilevel nature of the dataset creates conceptual and statistical limitations such as a risk for validity and robustness of the results (Arregle et. al, 2006). Similarly, in the scholarly field of FDI location decisions which poses a multilevel research question, the use of HLM is appropriate but has hardly been used.

Though the data is longitudinal by nature, time series analysis is not an appropriate methodological tool as it requires observing each firm for a larger period of time such as 50 or more times (Tabachnik \& Fidell, 2007).

As the data in the dissertation has 3 levels namely location decision level, year level and the firm level and since the outcome variable is dichotomous namely developed nation or emerging market; a 3level Bernoulli HLM is an appropriate methodological tool to analyze this dataset. Bernoulli HLM has been suggested for entry mode research where the outcome variable is dichotomous (Arregle et. al, 2006). 
For building models at each of the three levels, the approach used by Arregle et. al, 2006) is followed. The model building begins with an unconditional model and in the second step, all level-1 control variables are entered (though Arregle et. al, 2006 enter the variables one at a time) and only those control variables are retained that are found to be statistically significant with $p<0.05$ in line with Arregle et. al (2006). In the third step, dichotomous independent variable named purpose that denotes strategy (whether market-seeking or labor-seeking) is entered for each of the location decisions. This completes the level 1 model. Once the level 1 mode is in place, the variables at the level 2 should be introduced (Bliese \& Ployhart, 2002). Hence, the fourth step is to build the level 2 model.

For building the level 2 model; the control variables namely time, log of sales, cash, and return on sales are entered together. As in the step 2, only those variables that are found to be statistically significant are retained for further analysis. In the fifth step, the independent variables pertaining to firm resources are entered. This completes the level 2 model. In the sixth step, the variable called BusinessGroup is entered at the level of the firm. This step introduces the third and the last level in the model. This step completes the introduction of all linear effects in the 3-level model.

In the seventh and the last step, the interaction terms of firm resources with firm strategy are entered one by one. The interaction terms are introduced not as a multiplicative term but by varying the slope of the purpose variable by the firm resources. The statistical significance of the interaction term is checked.

The step-by-step approach from univariate to bivariate to trivariate adopted in the dissertation is recommended for the multilevel model as a saturated level-1 model is helpful only when the sample size is very large (Raudenbush \& Bryk, 2002). At each step, decision whether or not to retain a variable in the model for further analysis is undertaken (Arregle et. al, 2006).

At each step, two decisions need to be taken before running the analysis. First, if a variable needs to be entered as uncentered, group-centered, or grand-centered at the level 1 and level 2. Second, if the intercept or slope pertaining to the variable needs to be specified as fixed, random, or non-randomly varying. Enders \& Tofighi (2007) suggest group-centering the variables when the primary interest is to (i) check the relationship between a level-1 predictor and the outcome variables and (ii) when the cross-level 
interactions are of interest. This dissertation primarily looks at the relationship between the firm strategy (denoted by the variable called purpose which is a level 1 variable) and the firms' international location decision. The dissertation also seeks to understand if the interaction of firms' resources which are level 2 variables with purpose (a level 1 variable) is statistically significant. So, in line with the recommendations of Enders \& Tofighi (2007), all variables are group-centered.

On the question of random, fixed, or non-randomly varying specification of the intercept and slopes, variables are entered as randomly varying initially, and the estimated reliability and pace of model convergence, i.e. whether quick or slow to converge, are checked. Raudenbush \& Bryk (2002) suggest replacing random variation with fixed variation for reliability estimates of less than 0.1 .

The 3-level Bernoulli HLM gives the option to use Laplace iterations. Laplace estimation gives the deviance ratio to test the overall model fit at each subsequent model (Raudenbush \& Bryk, 2002).

As explained elsewhere, the 32 Indian software firms in the dataset have made 650 international location decisions between April 2000 and March 2009. These 650 location decisions make level 1 of the dataset. The 9 years during which the data pertaining to the firm resources has been collected for the 32 firms form level 2 of the dataset. There are 201 observations at level 2 and it shows that not every firm makes international location decision in each of the year of the study and many firms make multiple location decisions in a year. The variable business-group is time-invariant for the sampled 32 firms and it forms level 3 (firm-level) of the dataset. Thus, the dataset is unbalanced as number of location decisions per firm varies.

Correlation Matrix and Variance-Inflation Factor (VIF) Results

Before the actual building of HLM Bernoulli model begins; correlations, and VIFs of the variables are checked. The correlation matrix and collinearity statistics are given in Table 13 and Table 14 below.

Table 13: Correlation Table

\begin{tabular}{|r|l|r|r|r|r|r|r|}
\hline & & 1 & 2 & 3 & 4 & 5 & 6 \\
\hline 1 & Developed & 1 & & & & & \\
\hline 2 & Rentry & .280 & 1 & & & & \\
\hline 3 & Purpose & $.310^{*}$ & $-.098^{*}$ & 1 & & & \\
\hline
\end{tabular}




\begin{tabular}{|c|c|c|c|c|c|c|c|}
\hline 4 & EntryMode & .029 & .044 & $.117^{* *}$ & 1 & & \\
\hline 5 & LogofSales & -.314 & .120 & $-.261^{\star \prime}$ & .061 & 1 & \\
\hline 6 & Profit & -.280 & .134 & $-.287^{* \pi}$ & $.145^{\prime \prime}$ & .776 & 1 \\
\hline 7 & ROS & -.068 & .106 & -.058 & .094 & .322 & .277 \\
\hline 8 & Cash & -.217 & .068 & $-.197^{* 11}$ & .094 & .539 & $.737^{\pi \prime}$ \\
\hline 9 & logtotalempl & -.303 & .117 & $-.275^{n}$ & .029 & .975 & .776 \\
\hline 10 & logofswemp & -.308 & $.107^{\star \star}$ & $-.277^{* *}$ & .029 & $.969^{* \pi}$ & $.782^{\star \star}$ \\
\hline 11 & CMMI & -.174 & .095 & -.217 & -.094 & .457 & .378 \\
\hline 12 & KMSW & -.224 & .024 & $-.233^{\pi}$ & -.164 & .501 & $.361^{\pi}$ \\
\hline 13 & BusinessGroup & -.063 & $.159^{\prime \prime}$ & -.042 & .211 & .228 & $.258^{\pi n}$ \\
\hline 14 & IndiaGDC & $-.294^{*}$ & .121 & $-.253^{k \prime}$ & $.223^{*}$ & $.805^{\star \star}$ & $.810^{\star \star n}$ \\
\hline 15 & WageBillperemployee & -.132 & .058 & -.085 & -.092 & .237 & .129 \\
\hline 16 & Internationalizationexp & -.238 & $.142^{x "}$ & -.190 & .100 & $.764 \pi$ & $.639^{* 11}$ \\
\hline 17 & logofGDP & .332 & .464 & .056 & .015 & -.226 & $-.123^{\pi}$ \\
\hline 18 & logoftax & $.251^{\star \prime}$ & $.183^{x \prime}$ & $.168^{\star \star}$ & .031 & -.176 & $-.113^{*}$ \\
\hline 19 & FirmAge & -.254 & $.165^{\star \prime}$ & $-.183^{n}$ & $.243^{\pi \prime}$ & $.787^{\prime \prime}$ & $.696 \pi$ \\
\hline 20 & logofInflation & -.326 & -.066 & -.051 & -.047 & .180 & $.139^{* 11}$ \\
\hline 21 & ICT & .708 & $.293^{\pi /}$ & .208 & .044 & -.116 & $-.109^{*}$ \\
\hline 22 & logofPopulation & -.162 & .314 & -.110 & -.002 & -.119 & -.021 \\
\hline 23 & Institution & .690 & .310 & $.188^{\prime \prime}$ & .046 & -.272 & $-.218^{\pi /}$ \\
\hline 24 & logofGeoDistance & $.235^{\star \prime}$ & .329 & -.080 & .066 & -.061 & .008 \\
\hline 25 & TimeDiff & .259 & $.403^{\pi}$ & .003 & .076 & -.130 & -.046 \\
\hline 26 & IsEnglishSpoken & .138 & .157 & .116 & .011 & -.142 & -.114 \\
\hline 27 & logofFDItock & .416 & $.464^{\pi}$ & .050 & .022 & -.216 & -.126 \\
\hline 28 & ExchangeRate & .199 & .055 & .053 & .012 & -.018 & -.047 \\
\hline 29 & logoflabor & $.804 \%$ & $.282^{11}$ & $.312^{n}$ & .033 & $-.365^{\pi /}$ & $-.332^{* 1}$ \\
\hline 30 & CulturalDistance & $.364^{n}$ & $.111^{* k}$ & $.107^{* 1}$ & $.083^{k}$ & -.062 & -.076 \\
\hline 31 & HDI & .779 & $.257^{\pi}$ & $.214^{\pi}$ & .059 & $-.208^{n}$ & $-.201^{\pi \prime}$ \\
\hline
\end{tabular}


Table 13: Correlation Table (Cont'd)

\begin{tabular}{|c|c|c|c|c|c|c|c|}
\hline & & 7 & 8 & 9 & 10 & 11 & 12 \\
\hline 7 & ROS & 1 & & & & & \\
\hline 8 & Cash & $.210^{\pi}$ & 1 & & & & \\
\hline 9 & logtotalempl & $.309^{*}$ & $.537^{\star \star}$ & 1 & & & \\
\hline 10 & logofswemp & .297 & .543 & .996 & 1 & & \\
\hline 11 & CMMI & .207 & $.292^{n}$ & $.492^{n}$ & $.501^{m}$ & 1 & \\
\hline 12 & KMSW & .075 & $.255^{n}$ & .506 & .526 & $.465^{\prime \prime}$ & 1 \\
\hline 13 & BusinessGroup & .036 & -.059 & .234 & $.223^{*}$ & .120 & -.027 \\
\hline 14 & IndiaGDC & $.293^{* \prime}$ & $.440 "$ & $.817^{* *}$ & .830 & .414 & $.508^{*}$ \\
\hline 15 & WageBillperemployee & .027 & .250 & .193 & .200 & .186 & .233 \\
\hline 16 & Internationalizationexp & $.175^{\Uparrow \prime}$ & .356 & $.767^{\pi}$ & $.755^{n}$ & .160 & $.335^{n}$ \\
\hline 17 & logofGDP & -.124 & -.056 & -.214 & $-.212^{\pi / 1}$ & -.074 & -.090 \\
\hline 18 & logoftax & -.063 & -.065 & -.176 & -.170 & -.054 & -.073 \\
\hline 19 & FirmAge & .325 & .335 & .774 & .765 & $.245^{\prime}$ & .247 \\
\hline 20 & logofInflation & .014 & .127 & $.176^{\pi}$ & .177 & .162 & .136 \\
\hline 21 & ICT & -.081 & -.072 & -.098 & $-.102^{n-1}$ & .031 & -.078 \\
\hline 22 & logofPopulation & -.086 & .026 & $-.117^{*}$ & $-.112^{* n}$ & -.041 & -.005 \\
\hline 23 & Institution & -.077 & -.176 & -.260 & -.265 & -.150 & -.152 \\
\hline 24 & logofGeoDistance & -.043 & .000 & -.051 & -.049 & -.069 & -.007 \\
\hline 25 & TimeDiff & -.069 & -.018 & $-.123^{\pi / 1}$ & -.122 & -.079 & -.026 \\
\hline 26 & IsEnglishSpoken & -.082 & -.057 & -.144 & -.148 & -.028 & -.028 \\
\hline 27 & logofFDItock & -.104 & -.057 & -.204 & -.204 & $-.087^{*}$ & -.105 \\
\hline 28 & ExchangeRate & .071 & -.042 & -.014 & -.009 & .012 & .037 \\
\hline 29 & logoflabor & -.068 & -.268 & -.356 & -.357 & -.296 & -.226 \\
\hline 30 & CulturalDistance & .037 & -.050 & -.062 & -.060 & -.086 & -.094 \\
\hline 31 & HDI & -.034 & -.141 & -.196 & -.199 & -.141 & -.161 \\
\hline
\end{tabular}

Table 13: Correlation Table (Cont'd)

\begin{tabular}{|r|l|r|r|r|r|r|r|}
\hline & & 13 & 14 & 15 & 16 & 17 & 18 \\
\hline 13 & BusinessGroup & 1 & & & & & \\
\hline 14 & IndiaGDC & $.385^{\star \prime}$ & 1 & & & & \\
\hline 15 & WageBillperemployee & $-.240^{\star \prime}$ & .039 & 1 & & & \\
\hline
\end{tabular}




\begin{tabular}{|c|c|c|c|c|c|c|c|}
\hline 16 & Internationalizationexp & $.154^{\star \star}$ & $.695^{\star *}$ & $.133^{\star *}$ & 1 & & \\
\hline 17 & logofGDP & -.037 & -.186 & .008 & -.130 & 1 & \\
\hline 18 & logoftax & -.029 & -.124 & .005 & -.138 & $.411^{*}$ & 1 \\
\hline 19 & FirmAge & .380 & .776 & .048 & $.835^{\star \prime}$ & $-.166^{\pi \prime}$ & -.128 \\
\hline 20 & logofInflation & .016 & $.168^{\pi \prime}$ & $.116^{\star \prime}$ & $.104^{\pi}$ & $-.167^{n}$ & .057 \\
\hline 21 & ICT & -.049 & $-.145^{n \pi}$ & -.041 & -.090 & $.360 "$ & .065 \\
\hline 22 & logofPopulation & -.010 & -.071 & .037 & -.054 & .824 & $.337^{*}$ \\
\hline 23 & Institution & -.047 & -.232 & -.102 & -.186 & .242 & -.096 \\
\hline 24 & logofGeoDistance & -.019 & -.015 & .041 & .022 & $.600^{\pi}$ & $.207^{n-1}$ \\
\hline 25 & TimeDiff & -.019 & -.065 & .014 & -.047 & $.609^{\pi \prime}$ & .311 \\
\hline 26 & IsEnglishSpoken & -.049 & $-.118^{\star *}$ & -.016 & -.140 & -.010 & .048 \\
\hline 27 & logofFDItock & -.067 & $-.187^{\star *}$ & .004 & -.120 & $.828^{\star \prime}$ & $.158^{\star \star}$ \\
\hline 28 & ExchangeRate & -.015 & .012 & -.008 & -.014 & .061 & .012 \\
\hline 29 & logoflabor & -.055 & -.309 & -.117 & $-.241^{\pi *}$ & $.463^{\pi \prime}$ & $.183^{n}$ \\
\hline 30 & CulturalDistance & -.019 & -.060 & -.016 & -.022 & $.194^{\star \prime}$ & .017 \\
\hline 31 & HDI & -.051 & -.210 & -.080 & -.130 & $.373^{*}$ & .112 \\
\hline
\end{tabular}

Table 13: Correlation Table (Cont'd)

\begin{tabular}{|c|c|c|c|c|c|c|c|}
\hline & & 19 & 20 & 21 & 22 & 23 & 24 \\
\hline 19 & FirmAge & 1 & & & & & \\
\hline 20 & logofInflation & $.113^{n}$ & 1 & & & & \\
\hline 21 & ICT & -.132 & $-.298^{* 1}$ & 1 & & & \\
\hline 22 & logofPopulation & -.074 & .027 & $-.128^{* \prime}$ & 1 & & \\
\hline 23 & Institution & $-.202^{k \prime \prime}$ & $-.393^{* *}$ & $.655^{\star x}$ & -.160 & 1 & \\
\hline 24 & logofGeoDistance & -.011 & -.054 & .315 & $.452^{n}$ & .317 & 1 \\
\hline 25 & TimeDiff & -.066 & -.040 & $.288^{n}$ & $.465^{n}$ & $.408^{\pi n}$ & .826 \\
\hline 26 & IsEnglishSpoken & -.125 & .121 & .060 & -.057 & $.438^{n}$ & .051 \\
\hline 27 & logofFDItock & -.170 & $-.231^{\star \star}$ & $.497^{\star *}$ & $.609^{*}$ & $.477^{\star *}$ & $.591{ }^{\star}$ \\
\hline 28 & ExchangeRate & -.016 & $-.239^{* *}$ & $.125^{\star \prime}$ & -.053 & $.135^{\star *}$ & .057 \\
\hline 29 & logoflabor & $-.260^{\circ}$ & -.384 & $.613^{\pi}$ & .020 & $.597^{*}$ & .398 \\
\hline 30 & CulturalDistance & -.034 & $-.245^{\prime \prime}$ & $.527^{\pi}$ & -.064 & $.207^{*}$ & .366 \\
\hline 31 & HDI & $-.162^{*}$ & $-.462^{\star \star}$ & .820 & $-.155^{* \pi}$ & $.661 "$ & $.352^{\star \star}$ \\
\hline
\end{tabular}


Table 13: Correlation Table (Cont'd)

\begin{tabular}{|c|c|c|c|c|c|c|c|c|}
\hline & & 25 & 26 & 27 & 28 & 29 & 30 & 31 \\
\hline 25 & TimeDiff & 1 & & & & & & \\
\hline 26 & IsEnglishSpoken & .368 & 1 & & & & & \\
\hline 27 & logofFDItock & $.583^{\star \prime}$ & $.087^{*}$ & 1 & & & & \\
\hline 28 & ExchangeRate & -.035 & -.056 & .132 & 1 & & & \\
\hline 29 & logoflabor & .360 & .034 & $.495^{n}$ & $.211^{11}$ & 1 & & \\
\hline 30 & CulturalDistance & $.138^{\pi /}$ & -.322 & $.183^{n}$ & $.149^{\prime \prime}$ & $.510^{m}$ & 1 & \\
\hline 31 & HDI & $.310^{*}$ & -.011 & $.467^{* \pi}$ & $.234^{* *}$ & .774 & $.531 *$ & 1 \\
\hline
\end{tabular}

** $\mathrm{p}<0.01, * \mathrm{p}<0.05$ (2-tailed test)

Table 14: Collinearity Statistics

\begin{tabular}{|c|c|c|}
\hline & \multicolumn{2}{|c|}{ Collinearity Statistics } \\
\hline & Tolerance & VIF \\
\hline (Constant) & & \\
\hline Rentry & .581 & 1.722 \\
\hline Purpose & .714 & 1.401 \\
\hline EntryMode & .706 & 1.417 \\
\hline LogofSales & .040 & 25.272 \\
\hline Profit & .133 & 7.533 \\
\hline ROS & .717 & 1.394 \\
\hline Cash & .297 & 3.366 \\
\hline logtotalempl & .005 & 189.353 \\
\hline logofswemp & .006 & 162.049 \\
\hline CMMI & .496 & 2.016 \\
\hline
\end{tabular}




\begin{tabular}{|c|c|c|}
\hline FirmAge & .149 & 6.717 \\
\hline KMSW & .468 & 2.138 \\
\hline BusinessGroup & .564 & 1.774 \\
\hline IndiaGDC & .125 & 8.017 \\
\hline WageBillperemployee & .738 & 1.354 \\
\hline Internationalizationexp & .183 & 5.455 \\
\hline logofgdp & .038 & 26.435 \\
\hline logoftax & .646 & 1.549 \\
\hline logofInflation & .659 & 1.518 \\
\hline ICT & .184 & 5.430 \\
\hline logofpopulation & .045 & 22.096 \\
\hline logofGeoDistance & .187 & 5.351 \\
\hline TimeDiff & .166 & 6.006 \\
\hline HDI & .119 & 8.405 \\
\hline IsEnglishSpoken & .495 & 2.020 \\
\hline logoffdistk & .187 & 5.347 \\
\hline ExchangeRate & .838 & 1.194 \\
\hline logoflaborrate & .232 & 4.301 \\
\hline CulturalDistance & .404 & 2.477 \\
\hline
\end{tabular}

The correlation matrix shows that many variables are highly correlated $(r>0.70)$ with each other and with the dependent variable. The VIFs for these variables are also high (VIF $>4.0$ ), which may result in multicollinearity and may bias the statistical results. The variables that are highly correlated with the 
dependent variable are not retained in the model for further analysis. The variables that are highly correlated with the dependent variable are ICT $(r=0.71, p<0.01)$, Institution $(r=0.70, p<0.01)$, HDI $(r=$ $0.78, \mathrm{p}<0.01)$, logoflabor $(\mathrm{r}=0.81, \mathrm{p}<0.01)$. The VIFs for these variables were also greater than 4 and tolerance less than 0.2 as can be seen in the table 14 above, indicating that multicollinearity among the variables may be present. This is likely to be the case, as developed nations receive higher scores for their institutions, ICT and HDI than emerging markets. The labor cost is also higher in developed ountries than emerging markets. So, these control variables are dropped from further analysis.

The variables on the left side of the equation that are highly correlated with each other are as follows.

- $\quad \operatorname{logofsales}$ with profit $(\mathrm{r}=0.78, \mathrm{p}<0.01)$, logtotalempl $(\mathrm{r}=0.98, \mathrm{p}<0.01)$, logofswemp $(\mathrm{r}=0.97$, $\mathrm{p}<0.01)$, firm age $(\mathrm{r}=0.79, \mathrm{p}<0.01)$ indiagdc $(\mathrm{r}=0.81, \mathrm{p}<0.01)$, and internationalexp $(\mathrm{r}=$ $0.76, \mathrm{p}<0.01)$

- $\operatorname{logofgdp}$ with logofpopulation $(\mathrm{r}=0.82, \mathrm{p}<0.01)$, and $\operatorname{logoffdistk}(\mathrm{r}=0.83, \mathrm{p}<0.01)$;

- $\quad$ loggeodistance with timediff $(\mathrm{r}=0.83, \mathrm{p}<0.01)$.

One variable from each set of highly correlated independent variables are included in further analysis and model building. Hence, logofsales, logofgdp, timediff are retained while other variables are dropped from the HLM model. The VIFs for the dropped variables were also greater than 4 as can be seen in table 14.

The list of independent and control variables entered in the HLM Bernoulli model is as follows.

The dependent variable is dichotomous $(1=$ developed country, $0=$ emerging market $)$.

Table 15: List of Variables in HLM

\begin{tabular}{|l|l|l|}
\hline Level of the model & Control Variable & Independent Variable \\
\hline Level 1 & Reentry & \\
\hline & Entrymode & \\
\hline & Logofgdp & \\
\hline & Logoftax & \\
\hline & Logofinflation & \\
\hline
\end{tabular}




\begin{tabular}{|l|l|l|}
\hline & Timediff & \\
\hline & isenglishspoken, & \\
\hline & Exchangeratevolatility & \\
\hline & Culturaldistance & \\
\hline Level 2 & & purpose \\
\hline & Logofsales & \\
\hline & ROS & \\
\hline & Cash & \\
\hline & Time & CMMI \\
\hline & & KMSW \\
\hline Level 3 & & wagebillperemployee \\
\hline
\end{tabular}

The descriptive statistics (mean and standard deviation), correlation matrix, and VIF for the above variables are calculated again and are given in the following tables.

Table 16: Descriptive Statistics

\begin{tabular}{|l|r|rr|}
\hline & Mean & \multicolumn{2}{|c|}{ Std. Deviation } \\
\hline Developed & .734 & .442 \\
\hline Rentry & .408 & .492 \\
\hline Purpose & .785 & .411 \\
\hline EntryMode & .766 & .424 \\
\hline LogofSales & & 1.176 \\
& & .164 & .122 \\
\hline ROS & & 1402.333 \\
\hline Cash & 662.505 & \\
\hline
\end{tabular}




\begin{tabular}{|c|c|c|}
\hline CMMI & .574 & .495 \\
\hline KMSW & .669 & .471 \\
\hline BusinessGroup & .474 & .500 \\
\hline WageBillperemployee & .076 & .032 \\
\hline logofGDP & 27.434 & 1.729 \\
\hline logoftax & 3.428 & .284 \\
\hline logofInflation & 2.274 & .441 \\
\hline TimeDiff & 4.744 & 2.790 \\
\hline IsEnglishSpoken & .642 & .480 \\
\hline ExchangeRate & 1.006 & .114 \\
\hline CulturalDistance & 1.474 & .742 \\
\hline
\end{tabular}

Out of 650 international locations chosen by Indian software companies, 510 locations have been chosen for a market-seeking strategy, whereas 140 locations have been chosen for a labor-seeking strategy. Out of the 32 firms, the maximum location decisions made by a firm between April 2000 and March 2009 are 66 , while the minimum location decisions made are 3 by another firm in the same period. Out of 650 international location decisions, 498 have been done with a fully-owned subsidiary entry mode. Out of 32 firms, 13 firms belonged to a business group while the remaining 19 firms did not have such an affiliation. Table 17: Correlation Table of Variables in HLM

\begin{tabular}{|c|c|c|c|c|c|c|c|c|c|c|}
\hline & & 1 & 2 & 3 & 4 & 5 & 6 & 7 & 8 & 9 \\
\hline 1 & Developed & 1 & & & & & & & & \\
\hline 2 & Rentry & .280 & 1 & & & & & & & \\
\hline 3 & Purpose & $.311 *$ & -.098 & 1 & & & & & & \\
\hline 4 & EntryMode & .029 & .044 & $.117^{\prime \prime}$ & 1 & & & & & \\
\hline 5 & LogofSales & -.314 & .120 & -.261 & .061 & 1 & & & & \\
\hline 6 & ROS & -.068 & $.106^{* \prime}$ & -.058 & .094 & 322 & 1 & & & \\
\hline 7 & Cash & $-.217^{m \prime}$ & .068 & $-.197^{\prime \prime}$ & $.094^{\circ}$ & .539 & $210^{\prime \prime}$ & 1 & & \\
\hline 8 & CMMI & -.174 & .095 & -.217 & -.094 & $.457^{\prime \prime}$ & 207 & .292 & 1 & \\
\hline
\end{tabular}




\begin{tabular}{|c|c|c|c|c|c|c|c|c|c|c|}
\hline 9 & KMSW & $-.224^{* *}$ & .024 & $-.233^{* *}$ & $-.164^{* *}$ & $.501^{* *}$ & .075 & $.255^{* *}$ & $.465^{* *}$ & \\
\hline 10 & BusinessGroup & -.063 & .159 & -.042 & $.211^{\prime \prime}$ & .228 & .036 & -.059 & .120 & -.027 \\
\hline 11 & & $-.132^{* 1 *}$ & .058 & $-.085^{*}$ & -.092 & $.237^{* 1}$ & .027 & $250^{\pi \prime}$ & $.186^{n}$ & $.233^{*}$ \\
\hline 12 & gofGDP & .332 & .464 & .056 & .015 & -.226 & -.124 & -.056 & $\begin{array}{l}-.074 \\
\end{array}$ & $-.090^{\circ}$ \\
\hline 13 & logoftax & .251 & .183 & .168 & .031 & -.176 & -.063 & -.065 & -.054 & -.073 \\
\hline 14 & logoflnfla & -.326 & -.066 & -.051 & -.047 & $.180^{* \prime}$ & .014 & $.127^{\prime \prime}$ & $.162^{\prime \prime}$ & .136 \\
\hline 15 & TimeDiff & $.259^{\circ}$ & $.403^{\prime \prime}$ & .003 & .076 & -.130 & -.069 & -.018 & $-.079^{\circ}$ & -.026 \\
\hline 16 & $\begin{array}{l}\text { IsEnglis| } \\
\mathrm{n}\end{array}$ & $.138^{\prime \prime}$ & $.157^{\circ}$ & .116 & .011 & -.142 & -.082 & -.057 & -.028 & -.028 \\
\hline 17 & ExchangeRate & .199 & .055 & .053 & .012 & -.018 & .071 & -.042 & .012 & .037 \\
\hline 18 & CulturalDistance & .364 & $.111^{\prime \prime}$ & $.107^{\prime \prime}$ & $.083^{\circ}$ & -.062 & .037 & -.050 & $-.086^{\circ}$ & -.094 \\
\hline
\end{tabular}

Table 17: Correlation Table of Variables in HLM (Cont'd)

\begin{tabular}{|c|c|c|c|c|c|c|c|c|c|c|}
\hline & & 10 & 11 & 12 & 13 & 14 & 15 & 16 & 17 & 18 \\
\hline 10 & BusinessGroup & 1 & & & & & & & & \\
\hline 11 & WageBillperemployee & $-.240^{*}$ & 1 & & & & & & & \\
\hline 12 & logofGDP & -.037 & .008 & 1 & & & & & & \\
\hline 13 & logoftax & -.029 & .005 & $.411^{*}$ & 1 & & & & & \\
\hline 14 & logoflnflation & .016 & $.116^{*}$ & $-.167^{*}$ & .057 & 1 & & & & \\
\hline 15 & TimeDiff & -.019 & .014 & $.609^{*}$ & $.311^{*}$ & -.040 & 1 & & & \\
\hline 16 & IsEnglishSpoken & -.049 & -.016 & -.010 & .048 & $.121^{*}$ & $.368^{*}$ & 1 & & \\
\hline 17 & ExchangeRate & -.015 & -.008 & .061 & .012 & $-.239^{*}$ & -.035 & -.056 & 1 & \\
\hline 18 & CulturalDistance & -.019 & -.016 & $.194^{*}$ & .017 & $-.245^{*}$ & $.138^{*}$ & $-.322^{*}$ & $.149^{*}$ & 1 \\
\hline
\end{tabular}

It can be observed from the correlation matrix in Table 17 that none of the variables are highly correlated with $\mathrm{r}<0.7$.

Table 18: Collinearity Statistics of Variables in HLM

\begin{tabular}{|l|r|c|}
\hline & Tolerance & VIF \\
\hline Rentry & .635 & 1.574 \\
\hline Purpose & .824 & 1.214 \\
\hline EntryMode & .865 & 1.156 \\
\hline LogofSales & .394 & 2.535 \\
\hline ROS & .834 & 1.199 \\
\hline Cash & .639 & 1.565 \\
\hline CMMI & .671 & 1.491 \\
\hline KMSW & .609 & 1.641 \\
\hline
\end{tabular}




\begin{tabular}{|l|r|r|} 
BusinessGroup & .743 & 1.346 \\
\hline WageBillperemployee & .819 & 1.220 \\
\hline logofGDP & .410 & 2.441 \\
\hline logoftax & .774 & 1.293 \\
\hline logofInflation & .826 & 1.211 \\
\hline TimeDiff & .435 & 2.298 \\
\hline IsEnglishSpoken & .580 & 1.726 \\
\hline ExchangeRateVolatility & .909 & 1.100 \\
\hline CulturalDistance & .738 & 1.356 \\
\hline
\end{tabular}

It can be seen from the collinearity statistics that none of these variables has VIF $>4.0$ and tolerance $<0.20$ as shown in Table 18. So, these variables are not multicollinear with each other. Result

The Laplace iterations of the intercept-only or the unconditional model showed reliability estimates of greater than 0.1 (reliability estimates of random level 1 coefficient $=0.296$, reliability estimates for random level 2 coefficient $=0.316$ ) and hence the intercept can be taken as varying randomly (Raudenbush \& Bryk, 2002). The p-value $(\mathrm{p}<0.001)$ for fixed effect indicates that G000 is significantly different from 0 . The deviance for the unconditional model is 1917.6509 with number of estimated parameters $=3$ as shown in model 1 of Table 22 .

Summary of the model specified in equation format is as given below:

Level-1 Model

$$
\begin{aligned}
& \operatorname{Prob}(\mathrm{Y}=1 \mid \mathrm{B})=\mathrm{P} \\
& \log [\mathrm{P} /(1-\mathrm{P})]=\mathrm{P} 0
\end{aligned}
$$

Level-2 Model

$$
\mathrm{P} 0=\mathrm{B} 00+\mathrm{R} 0
$$

Level-3 Model

$$
\mathrm{B} 00=\mathrm{G} 000+\mathrm{U} 00
$$


Intra-class correlation (ICC) for the 3-level Bernoulli model was calculated using the formula suggested for a 2-level Bernoulli model by Snijders \& Bosker (1999, page 224) with the ICC calculation approach adopted for 3 -level models with continuous dependent variables. ICC for level 3 is 0.08 , showing that $8 \%$ of the variance is at level 3. The ICC for level 3 and level 2 is 0.26 , showing that $26 \%$ of the variance is explained at level 2 and level 3 together. The ICC for level 2 is 0.21 , indicating that $21 \%$ of the variance is explained at level 2 alone. These ICC values are high given the fact that in educational research, ICC values between 0.05 and 0.2 are common (Snijders \& Bosker, 1999). Thus, a 3-level model is appropriate for analyzing the dataset.

Step 2 of the model-building:

All level 1 control variables as given in Table 19 are entered in a block in this step. The following table shows the statistical significance of each of these variables as obtained from Laplace iterations.

Table 19: Level 1 Control Variables

\begin{tabular}{|l|l|l|l|l|}
\hline Variable & Coefficient & T-ratio & Degrees of freedom & p-value \\
\hline Intercept & 2.321706 & 4.78 & 31 & $<0.001$ \\
\hline Reentry & 1.283209 & 1.360 & 640 & 0.175 \\
\hline entrymode & 1.985013 & 0.605 & 640 & 0.545 \\
\hline logofgdp & 0.387813 & 0.837 & 640 & 0.403 \\
\hline logoftax & 2.076442 & 1.584 & 640 & 0.113 \\
\hline logofinflation & -3.024463 & -3.284 & 640 & 0.001 \\
\hline Timediff & -0.089852 & -0.773 & 640 & 0.440 \\
\hline isenglishspoken & 2.133039 & 3.467 & 640 & 0.001 \\
\hline exchangeratevolatility & 5.604298 & 1.576 & 640 & 0.115 \\
\hline culturaldistance & 1.501494 & 4.042 & 640 & $<0.001$ \\
\hline
\end{tabular}

As can be observed from the above table, the statistically significant variables are logofinflation ( $p$ $<0.001)$, isenglishspoken $(\mathrm{p}<0.001)$, and culturaldistance $(\mathrm{p}<0.001)$. For each one unit increase in log of inflation, the odds that an Indian software firm is likely to choose a developed country over an emerging 
market, on an average, decreases by 0.06 , all else being equal. The odds that an Indian software firm is likely to choose a developed country over an emerging market increases, on an average, by 6.16 if the country happens to be an English speaking country, all else being equal. Similarly, for each one unit increase in cultural distance between India and the host country, the odds that an Indian software firm is likely to choose a developed country over an emerging market, on an average, increases by 4.63 , all else being equal.

For further model building, these 3 control variables are retained in the model and other level 1 control variables were dropped. The HLM analysis was run again with these 3 variables and the results are given in the following table.

Table 20: Selected Level 1 Control Variables

\begin{tabular}{|l|l|l|l|l|}
\hline Variable & Coefficient & T-ratio & Degrees of freedom & p-value \\
\hline Intercept & 1.936908 & 6.774 & 31 & $<0.001$ \\
\hline logofinflation & -2.830607 & -5.522 & 646 & $<0.001$ \\
\hline isenglishspoken & 1.819233 & 5.791 & 646 & $<0.001$ \\
\hline culturaldistance & 1.533392 & 5.741 & 646 & $<0.001$ \\
\hline
\end{tabular}

The deviance is 1789.33 (chi-square $=128.317$, d.f. $=3, \mathrm{p}<0.001$ ) as seen in Model 2 of Table 22.

Summary of the model specified in equation format is as given below:

Level-1 Model

$$
\begin{aligned}
& \operatorname{Prob}(\mathrm{Y}=1 \mid \mathrm{B})=\mathrm{P} \\
& \log [\mathrm{P} /(1-\mathrm{P})]=\mathrm{P} 0+\mathrm{P} 1 *(\text { LOGOFINF })+\mathrm{P} 2 *(\text { ISENGLIS })+\mathrm{P} 3 *(\mathrm{CULTURAL})
\end{aligned}
$$

Level-2 Model

$$
\begin{aligned}
& \mathrm{P} 0=\mathrm{B} 00+\mathrm{R} 0 \\
& \mathrm{P} 1=\mathrm{B} 10 \\
& \mathrm{P} 2=\mathrm{B} 20 \\
& \mathrm{P} 3=\mathrm{B} 30
\end{aligned}
$$


Level-3 Model

$$
\begin{aligned}
& \mathrm{B} 00=\mathrm{G} 000+\mathrm{U} 00 \\
& \mathrm{~B} 10=\mathrm{G} 100 \\
& \mathrm{~B} 20=\mathrm{G} 200 \\
& \mathrm{~B} 30=\mathrm{G} 300
\end{aligned}
$$

Step 3 of the model-building:

Level 1 independent variable namely purpose is introduced to the model in this step. As can be seen in Model 3 of Table 22, purpose is statistically significant $(p=0.01)$ with coefficient $=1.788301$ and odds ratio $=5.9792$. Thus, the probability of an Indian software company locating in a developed country with a market-seeking strategy is $92 \%$, all else being equal. On the other hand, the probability of an Indian software company locating in a developed country with a labor-seeking strategy is $65 \%$. Hence, hypothesis 1 is supported. The deviance for the model is 1764.246 (chi-square $=25.0877$, d.f. $=1, p<0.001$ ). As the deviance ratio goes down, it can be concluded that the model 3 is statistically significant.

Summary of the model specified in equation format is as given below:

Level-1 Model

$$
\begin{aligned}
& \operatorname{Prob}(\mathrm{Y}=1 \mid \mathrm{B})=\mathrm{P} \\
& \begin{aligned}
& \log [\mathrm{P} /(1-\mathrm{P})]= \mathrm{P} 0+\mathrm{P} 1 *(\mathrm{PURPOSE})+\mathrm{P} 2 *(\text { LOGOFINF })+\mathrm{P} 3 *(\text { ISENGLIS })+ \\
& \mathrm{P} 4 *(\mathrm{CULTURAL})
\end{aligned}
\end{aligned}
$$

Level-2 Model

$$
\begin{aligned}
& \mathrm{P} 0=\mathrm{B} 00+\mathrm{R} 0 \\
& \mathrm{P} 1=\mathrm{B} 10 \\
& \mathrm{P} 2=\mathrm{B} 20 \\
& \mathrm{P} 3=\mathrm{B} 30 \\
& \mathrm{P} 4=\mathrm{B} 40
\end{aligned}
$$

Level-3 Model

$$
\mathrm{B} 00=\mathrm{G} 000+\mathrm{U} 00
$$




$$
\begin{aligned}
& \mathrm{B} 10=\mathrm{G} 100 \\
& \mathrm{~B} 20=\mathrm{G} 200 \\
& \mathrm{~B} 30=\mathrm{G} 300 \\
& \mathrm{~B} 40=\mathrm{G} 400
\end{aligned}
$$

This completes level 1 model, leaving level 2 and level 3 models unspecified. The model is built further by introducing level 2 control variables in the next step.

Step 4 of the model-building:

The level 2 control variables namely logofsales, ROS, cash, and time are entered in this step. The results as given below in Table 21 show that none of these variables are statistically significant.

Table 21: Level 2 Control Variables

\begin{tabular}{|l|l|l|l|l|}
\hline Variable & Coefficient & T-ratio & Degrees of freedom & p-value \\
\hline logofsales & -0.657369 & -0.731 & 196 & 0.466 \\
\hline ROS & -1.485633 & -0.278 & 196 & 0.781 \\
\hline cash & -0.000186 & -0.711 & 196 & 0.478 \\
\hline Time & -0.181547 & -0.799 & 196 & 0.425 \\
\hline
\end{tabular}

All level 2 control variables except time are dropped. Time dummies are retained in the model for further analysis of the longitudinal dataset. The HLM is re-run with time as a level 2 control variable. As can be seen in Model 4 of Table 22, time becomes statistically significant $(\mathrm{p}<0.001)$ with coefficient $=-$ 0.396807 and odds ratio 0.6724 . With each passing year, the odds that an Indian software firm is likely to choose a developed market over an emerging country decreases, on an average, by 0.67 , all else being equal. Indian software firms, as they gain international experience, tend to move more into unchartered territories. The deviance for the model is 1730.20 (chi-square $=34.0455$, d.f. $=1, p<0.001$ ). It can be concluded that the model 4 is statistically significant.

Summary of the model specified in equation format is as given below:

Level-1 Model

$$
\operatorname{Prob}(\mathrm{Y}=1 \mid \mathrm{B})=\mathrm{P}
$$




\section{$\log [\mathrm{P} /(1-\mathrm{P})]=\mathrm{P} 0+\mathrm{P} 1 *(\mathrm{PURPOSE})+\mathrm{P} 2 *($ LOGOFINF $)+\mathrm{P} 3 *($ ISENGLIS $)+$ P4*(CULTURAL)}

Level-2 Model

$$
\begin{aligned}
& \mathrm{P} 0=\mathrm{B} 00+\mathrm{B} 01 *(\mathrm{TIME})+\mathrm{R} 0 \\
& \mathrm{P} 1=\mathrm{B} 10 \\
& \mathrm{P} 2=\mathrm{B} 20 \\
& \mathrm{P} 3=\mathrm{B} 30 \\
& \mathrm{P} 4=\mathrm{B} 40
\end{aligned}
$$

Level-3 Model

$$
\begin{aligned}
& \mathrm{B} 00=\mathrm{G} 000+\mathrm{U} 00 \\
& \mathrm{~B} 01=\mathrm{G} 010 \\
& \mathrm{~B} 10=\mathrm{G} 100 \\
& \mathrm{~B} 20=\mathrm{G} 200 \\
& \mathrm{~B} 30=\mathrm{G} 300 \\
& \mathrm{~B} 40=\mathrm{G} 400
\end{aligned}
$$

Step 5 of the model-building:

The level 2 independent variables serving as proxies for firm resources namely CMMI, KMSW, and wagebillperemployee are introduced in this step. None of the three variables are statistically significant (CMMI: $\mathrm{p}=0.067$; KMSW: $\mathrm{p}=0.121$; wagebillperemployee: $\mathrm{p}=0.083$ ) as can be seen in Model 5 of Table 22. The deviance drops to 1720.605 (chi-square $=9.595$, d.f. $=3, p=0.02$ ). The main effects of resources are not dropped in further analysis as controlling for the main effects is required before introducing the interaction terms in the model. This concludes the level 2 model, leaving the level 3 model unspecified. The level 3 is introduced in the next step. Summary of the model specified in equation format is as given below:

Level-1 Model

$$
\begin{aligned}
& \operatorname{Prob}(\mathrm{Y}=1 \mid \mathrm{B})=\mathrm{P} \\
& \log [\mathrm{P} /(1-\mathrm{P})]=\mathrm{P} 0+\mathrm{P} 1 *(\mathrm{PURPOSE})+\mathrm{P} 2 *(\text { LOGOFINF })+\mathrm{P} 3 *(\text { ISENGLIS })+
\end{aligned}
$$




\section{P4*(CULTURAL)}

Level-2 Model

$$
\begin{aligned}
\mathrm{P} 0 & =\mathrm{B} 00+\mathrm{B} 01 *(\mathrm{CMMI} \mathrm{MEA})+\mathrm{B} 02 *\left(\mathrm{KMSW} \_\mathrm{MEA}\right)+\mathrm{B} 03 *(\mathrm{WAGEBILL})+ \\
\mathrm{B} 04 *(\mathrm{TIME})+\mathrm{R} 0 & \\
\mathrm{P} 1 & =\mathrm{B} 10 \\
\mathrm{P} 2 & =\mathrm{B} 20 \\
\mathrm{P} 3 & =\mathrm{B} 30 \\
\mathrm{P} 4 & =\mathrm{B} 40
\end{aligned}
$$

Level-3 Model

$$
\begin{aligned}
& \mathrm{B} 00=\mathrm{G} 000+\mathrm{U} 00 \\
& \mathrm{~B} 01=\mathrm{G} 010 \\
& \mathrm{~B} 02=\mathrm{G} 020 \\
& \mathrm{~B} 03=\mathrm{G} 030 \\
& \mathrm{~B} 04=\mathrm{G} 040 \\
& \mathrm{~B} 10=\mathrm{G} 100 \\
& \mathrm{~B} 20=\mathrm{G} 200 \\
& \mathrm{~B} 30=\mathrm{G} 300 \\
& \mathrm{~B} 40=\mathrm{G} 400
\end{aligned}
$$

Step 6 of the model-building:

The level 3 control variable namely BusinessGroup which is the only time-invariant firm-level variable is introduced by grand-centering in this step of the model building. The variable is not statistically significant $(\mathrm{p}=0.79)$ as can be seen in Model 6 of Table 22 . The deviance drops by small value to 1720.2570 (chi-square $=0.3485$, d.f. $=1, p>0.5)$. The variable is, however, retained in the model as it is the only variable at level 3 and it is required to have at least one variable at level 3 to have a three-level model. This concludes level 3 of the model. The three interaction terms between purpose and each of the 
three resource variables namely CMMI, KMSW, and wagebillperemployee are introduced to the model one by one as the last step in the model building process.

Summary of the model specified in equation format is as given below:

Level-1 Model

$$
\begin{aligned}
& \operatorname{Prob}(\mathrm{Y}=1 \mid \mathrm{B})=\mathrm{P} \\
& \begin{array}{c}
\log [\mathrm{P} /(1-\mathrm{P})]=\mathrm{P} 0+\mathrm{P} 1 *(\mathrm{PURPOSE})+\mathrm{P} 2 *(\text { LOGOFINF })+\mathrm{P} 3 *(\text { ISENGLIS })+ \\
\mathrm{P} 4 *(\mathrm{CULTURAL})
\end{array}
\end{aligned}
$$

Level-2 Model

$$
\begin{aligned}
\mathrm{P} 0 & =\mathrm{B} 00+\mathrm{B} 01 *(\mathrm{CMMI} \mathrm{MEA})+\mathrm{B} 02 *\left(\mathrm{KMSW} \_\mathrm{MEA}\right)+\mathrm{B} 03 *(\mathrm{WAGEBILL})+ \\
& \mathrm{B} 04 *(\mathrm{TIME})+\mathrm{R} 0 \\
\mathrm{P} 1 & =\mathrm{B} 10 \\
\mathrm{P} 2 & =\mathrm{B} 20 \\
\mathrm{P} 3 & =\mathrm{B} 30 \\
\mathrm{P} 4 & =\mathrm{B} 40
\end{aligned}
$$

Level-3 Model

$$
\begin{aligned}
& \mathrm{B} 00=\mathrm{G} 000+\mathrm{G} 001 \text { (BUSINESS })+\mathrm{U} 00 \\
& \mathrm{~B} 01=\mathrm{G} 010 \\
& \mathrm{~B} 02=\mathrm{G} 020 \\
& \mathrm{~B} 03=\mathrm{G} 030 \\
& \mathrm{~B} 04=\mathrm{G} 040 \\
& \mathrm{~B} 10=\mathrm{G} 100 \\
& \mathrm{~B} 20=\mathrm{G} 200 \\
& \mathrm{~B} 30=\mathrm{G} 300 \\
& \mathrm{~B} 40=\mathrm{G} 400
\end{aligned}
$$

Step 7 of the model-building:

Cross-level interactions are introduced in this step. The conceptual model in the dissertation proposes that firm resources moderate the direct relationship between firm strategy and location choices. 
To test the hypotheses pertaining to the moderating effect of firm resources, interaction terms between purpose and CMMI, purpose and KMSW, and purpose and wagebillperemployee are introduced one by one to the model. The interactions between purpose and firm resources form cross-level interactions. With introductions of all three interaction terms, the HLM model is built completely.

Interaction between purpose and KMSW: As can be seen in Model 7 of Table 22, the interaction is not statistically significant $(\mathrm{p}=0.68)$. The deviance for the model is 1719.8187 (chi-square $=0.4383$, d.f. $=$ $1, p>0.50)$. The main effect of purpose remains statistically significant $(p=0.012)$. Thus, hypothesis 2 is not supported.

Interaction between purpose and wagebillperemployee: As can be seen in Model 8 of Table 22, the interaction is not statistically significant $(\mathrm{p}=0.768)$. The deviance for the model is 1719.8533 (chi-square $=0.4037$, d.f. $=1, p>0.50)$. The main effect of purpose remains statistically significant $(p=0.015)$. Hence, hypothesis 3 is not supported.

Interaction between purpose and CMMI: As can be seen in Model 9 of Table 22, the interaction is statistically significant $(\mathrm{p}=0.047)$. The deviance for the model is 1711.2668 (chi-square $=8.9902$, d.f. $=1$, $p=0.003)$. The main effect of purpose remains statistically significant $(p=0.005)$. The probability of an Indian software firm without CMMI level-5 appraisal locating in a developed country with a labor-seeking strategy is only $17 \%$, whereas the probability of an Indian software firm with CMMI level-5 appraisal locating in a developed country with a labor-seeking strategy is $85 \%$, all else being equal. The probability of an Indian software firm without CMMI level-5 appraisal locating in a developed country with a marketseeking strategy is $91 \%$, whereas the probability of an Indian software firm with CMMI level-5 appraisal locating in a developed country with a market-seeking strategy is $94 \%$, all else being equal. Thus, hypothesis 4 is supported.

The complete model in the equation format is specified below:

Level-1 Model

$$
\begin{aligned}
& \operatorname{Prob}(\mathrm{Y}=1 \mid \mathrm{B})=\mathrm{P} \\
& \begin{array}{rl}
\log [\mathrm{P} /(1-\mathrm{P})]= & \mathrm{P} 0+\mathrm{P} 1 *(\mathrm{PURPOSE})+\mathrm{P} 2 *(\text { LOGOFINF })+\mathrm{P} 3 *(\text { ISENGLIS })+ \\
\mathrm{P} 4 & *(\mathrm{CULTURAL})
\end{array}
\end{aligned}
$$


Level-2 Model

$$
\begin{aligned}
\mathrm{P} 0 & =\mathrm{B} 00+\mathrm{B} 01 *(\mathrm{CMMI} \mathrm{MEA})+\mathrm{B} 02 *\left(\mathrm{KMSW} \_\mathrm{MEA}\right)+\mathrm{B} 03 *(\mathrm{WAGEBILL})+ \\
& \mathrm{B} 04 *(\mathrm{TIME})+\mathrm{R} 0 \\
\mathrm{P} 1 & =\mathrm{B} 10+\mathrm{B} 11 *\left(\mathrm{CMMI} \_\mathrm{MEA}\right) \\
\mathrm{P} 2 & =\mathrm{B} 20 \\
\mathrm{P} 3 & =\mathrm{B} 30 \\
\mathrm{P} 4 & =\mathrm{B} 40
\end{aligned}
$$

Level-3 Model

$$
\begin{aligned}
& \mathrm{B} 00=\mathrm{G} 000+\mathrm{G} 001(\mathrm{BUSINESS})+\mathrm{U} 00 \\
& \mathrm{~B} 01=\mathrm{G} 010 \\
& \mathrm{~B} 02=\mathrm{G} 020 \\
& \mathrm{~B} 03=\mathrm{G} 030 \\
& \mathrm{~B} 04=\mathrm{G} 040 \\
& \mathrm{~B} 10=\mathrm{G} 100 \\
& \mathrm{~B} 11=\mathrm{G} 110 \\
& \mathrm{~B} 20=\mathrm{G} 200 \\
& \mathrm{~B} 30=\mathrm{G} 300 \\
& \mathrm{~B} 40=\mathrm{G} 400
\end{aligned}
$$

In the final model, only P0 and B00 were specified as random and others were specified as fixed effects. When coefficients other than P0 and B00 were specified as random, data analysis was slow to converge, reliability estimates were lower than 0.10 , and $p$-value for chi-square test for homogeneity was greater than 0.5 .

The summary of the statistical results of various models is given in the table below.

Table 22: HLM Results

\begin{tabular}{|l|r|r|r|r|r|r|}
\hline & Model 1 & Model 2 & Model 3 & Model 4 & Model 5 & Model 6 \\
\hline Intercept & $1.53^{* *}$ & $1.93^{* * *}$ & $2.02^{* * *}$ & $2.00^{* * *}$ & $2.01^{* * *}$ & $2.01^{* * *}$ \\
\hline
\end{tabular}




\begin{tabular}{|c|c|c|c|c|c|c|}
\hline Logofinflation & & $-2.83^{* * *}$ & $-2.85 * * *$ & $-2.64 * * *$ & $-2.53 * * *$ & $-2.52 * * *$ \\
\hline Isenglishspoken & & $1.81 * * *$ & $1.81 * * *$ & 1.80 *** & $1.80 * * *$ & $1.79 * * *$ \\
\hline Culturaldistance & & $1.53 * * *$ & $1.56^{* * *}$ & $1.47 * * *$ & $1.50^{* * *}$ & $1.51 * *$ \\
\hline Purpose & & & $1.78^{*}$ & $1.68^{*}$ & $1.68^{*}$ & $1.68^{*}$ \\
\hline Time & & & & $-.39 * * *$ & $-.42 * * *$ & $-.42 * *$ \\
\hline CMMI & & & & & 1.07 & 1.08 \\
\hline KMSW & & & & & -1.31 & -1.27 \\
\hline Wagebillperemployee & & & & & -11.36 & -10.20 \\
\hline BusinessGroup & & & & & & -0.25 \\
\hline Purpose*KMSW & & & & & & \\
\hline Purpose*wagebillperer & & & & & & \\
\hline Purpose*CMMI & & & & & & \\
\hline Deviance & 1917.65 & 1789.33 & 1764.24 & 1730.2 & 1720.60 & 1720.25 \\
\hline Estimated parameters & 3 & 6 & 7 & 8 & 11 & 12 \\
\hline Chi-square & & 128.31 & 25.08 & 34.04 & 9.59 & 0.34 \\
\hline d.f. & & 3 & 1 & 1 & 3 & 1 \\
\hline p-value & & $<0.001$ & $<0.001$ & $<0.001$ & 0.02 & $>0.5$ \\
\hline $\mathrm{N}$ & 650 & 650 & 650 & 650 & 650 & 650 \\
\hline Total number of firms & 32 & 32 & 32 & 32 & 32 & 32 \\
\hline
\end{tabular}

Table 22: HLM Results (Cont'd)

\begin{tabular}{|l|r|r|r|}
\hline & Model 7 & \multicolumn{1}{|l|}{ Model 8 } & \multicolumn{2}{|l|}{ Model 9 } \\
\hline Intercept & $2.03^{* * *}$ & $2.01^{* * *}$ & $2.06^{* * *}$ \\
\hline Logofinflation & $-2.52^{* * *}$ & $-2.50^{* *}$ & $-2.40^{* * *}$ \\
\hline Isenglishspoken & $1.80^{* *}$ & $1.80^{* *}$ & $1.86^{* *}$ \\
\hline Culturaldistance & $1.50^{* *}$ & $1.51^{* *}$ & $1.54^{* *}$ \\
\hline
\end{tabular}




\begin{tabular}{|c|c|c|c|}
\hline Purpose & $1.81^{*}$ & $1.63 *$ & $2.20 * *$ \\
\hline Time & $-.42 * *$ & $-.43 * *$ & $-.43 * *$ \\
\hline CMMI & 1.10 & 1.10 & 0.98 \\
\hline KMSW & -1.35 & -1.29 & -1.30 \\
\hline Wagebillperemployee & -11.73 & -8.09 & -13.04 \\
\hline BusinessGroup & -0.26 & -0.25 & -0.26 \\
\hline Purpose*KMSW & -1.44 & & \\
\hline Purpose*wagebillperemployee & & 7.68 & \\
\hline Purpose*CMMI & & & $-3.03 *$ \\
\hline Deviance & 1719.81 & 1719.85 & 1711.26 \\
\hline Estimated parameters & 13 & 13 & 13 \\
\hline Chi-square & 0.43 & 0.40 & 8.99 \\
\hline d.f. & 1 & 1 & 1 \\
\hline p-value & $>0.5$ & $>0.5$ & $<0.01$ \\
\hline $\mathrm{n}$ & 650 & 650 & 650 \\
\hline Total number of firms & 32 & 32 & 32 \\
\hline
\end{tabular}

$* * *$ denotes $\mathrm{p}<0.001, * *$ denotes $\mathrm{p}<0.01$, $*$ denotes $\mathrm{p}<0.05$.

The summary of the results obtained is presented in Table 23 below:

Table 23: Significant Hypotheses

\begin{tabular}{|l|c|}
\hline Hypothesis & Supported \\
\hline H1: International strategy determines the location choice of emerging market firms & Yes \\
such that Indian software firms when pursuing a market-seeking strategy are & \\
more likely to locate in a developed country than the firms pursing a labor- & \\
seeking strategy, which, in turn, are more likely to locate in an emerging & \\
country. & \\
\hline H2: There will be an interaction between type of international strategy of Indian & No \\
\hline
\end{tabular}




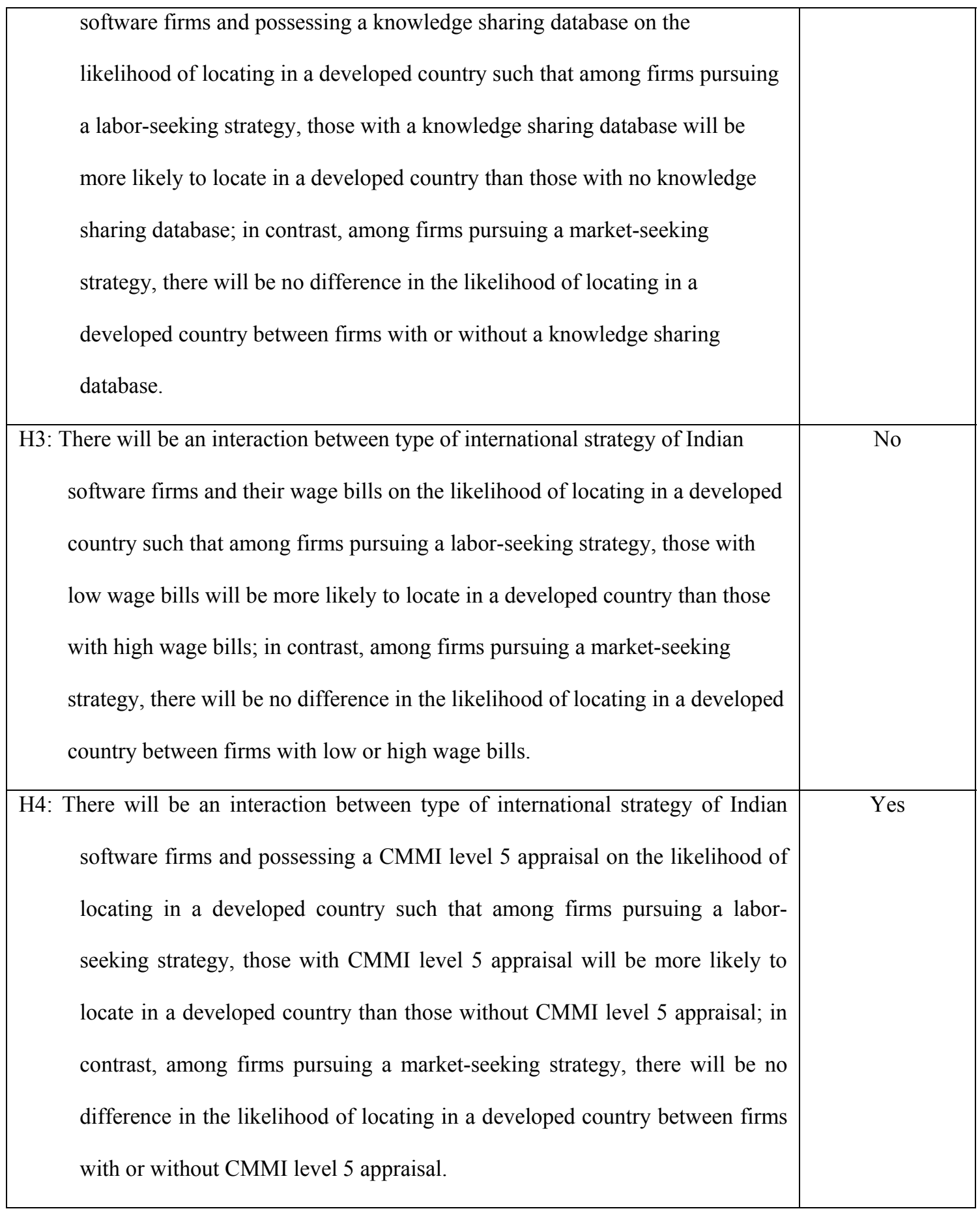

For checking if the results are sensitive to the choice of variables in the model, six separate HLM Bernoulli models were run by replacing the following highly correlated variables (i) logofgdp with 
logofpopulation; (ii) loggeodistance with timediff, (iii) logofsales with profit, (iv) logofsales with logtotalemp, (v) logofsales with indiagdc, (vii) logofsales with internationalexp. The results did not change. Discussion

Traditional theories explain the location decisions of multinational organizations, whether manufacturing or services, with help of country-specific variables such as macroeconomic factors, institutions, or agglomeration and distance between home and host countries. A small number of studies consider top management attributes such as its international experience and tenure for explaining the location decisions. An even smaller number of studies have analyzed the impact of firm resources and strategies on location decision of firms. This dissertation conceptualizes a comprehensive model that proposes firm resources and its strategies, country characteristics and distance as drivers of the international location decisions made by emerging market firms. The conceptual model is general enough to explain the location decisions of all multinational firms whether from developed or emerging market countries. However, the focus in the dissertation is on firms from emerging markets.

It is proposed in the conceptual model that emerging market firms possess different types of resources that make them select some internationalization strategies for foreign markets. Based on their internationalization strategies, emerging market firms choose apt location decisions. The model further proposes that the direct relationship between strategy and location decision is moderated by the resources of the firm. Thus, two firms following same internationalization strategy but having different resource type are likely to make different international location decisions, after controlling for various country and top management characteristics.

To empirically examine the conceptual model, a dataset of international location decisions made by Indian software firms between April 2000 and March 2009 was compiled. Indian software firms have been globalizing and have been establishing their operations overseas for many years. In a list of the top 40 Indian companies in terms of outward FDI approval compiled by Pradhan (2005), 14 companies are from the software industry. A study by Pradhan (2007) reports that Indian information and software technology firms are the most aggressive international investors from India. Thus, it became interesting to understand the factors responsible for the location decisions of Indian software companies. 
Traditional variables used in the extant literature to predict location decisions

Out of the various traditional variables in the location literature such as macroeconomic factors, agglomeration factors, and distances; inflation rates in the host country, whether or not English is spoken in a host country, and cultural distance between India and the host country significantly predicted the location decisions of Indian software companies. These firms are likely to choose a developed country over an emerging market for every unit increase in the cultural distance and when English is spoken in the two types of countries. The results obtained for cultural distance go contrary to the suggestions made in the IP model (Johanson \& Vahlne, 1977). Their likelihood of choosing a developed country over an emerging market country, however, decreases for every unit increase in annual inflation rate in the host country. Other variables such as GDP of the host country, tax rate, exchange rate fluctuations, or time differences between India and the host country location did not statistically significantly predict the location decisions of Indian software firms.

The reentry variable which denoted whether a firm was already present in a host country, surprisingly, did not statistically significantly predicted the location decisions of Indian software firms; the extant literature, though, suggests that firms tend to invest further in the countries where they have already invested. A probable reason for statistical non-significance of the variable could be that Indian software firms have largely located internationally with market-seeking strategy which may require lesser financial investment than other internationalization strategies such as labor-seeking strategy. Since the investment risk in market-seeking strategy is less for Indian software companies, these firms could afford to locate in different nations. Entry mode did not significantly predict the location decisions of Indian software companies.

Firm level control variables such as cash, sales, return on sales, age, or firm's international experience did not statistically significantly predicted the location choices of Indian software companies. Other often-studied variables such as advertising or R\&D intensity could not be incoproated in the dataset as the sampled Indian sotware companies invest very little or no amount in these two variables, as was evident from the annual reports of these companies. Time, when entered together with other firm-level control variables, was not statistically significant. However, when time was entered again without other 
firm-level control variables, it became significant, though the effect is not very large. It seems that Indian software firms demonstrate a propensity to locate in an emerging market with every passing year. The affiliation of an Indian software firm with a business group did not matter in their international location decisions. The firms' location patterns did not change as per their affiliation with a business group. Their first halt in international journey is a developed nation.

Independent variables in the dissertation

The predictor variable, internationalization strategy statistically significantly predicts the location decisions of Indian software firms. Indian software firms locate in developed nations when following the market-seeking strategy and in emerging markets when following the labor-seeking strategy. Indian software firms seem to be investing overseas more in line with their internationalization strategy than as per the 'distance' between India and host countries. The geographic distance, or cultural distance, or economic distance does not seem to affect the location decisions of these firms. On the contrary, increase in cultural distance increases the propensity of Indian software firms to locate in a developed nation. These firms have their first overseas destination in a developed nation. In this regard, it seems that Indian software firms follow the born-global hypothesis more than the prescriptions made by IP model.

The dissertation studied the impact of three resources of Indian software firms namely wage bill, successful appraisal at CMMI level-5, and whether or not the firm possesses an electronic knowledge sharing database. The conceptual model predicts a moderating impact of the firm resources on its location decision. In line with the model, the main effects of none of the three variables were statistically significant. When the interaction terms between strategy variable called purpose and these resources were entered in the model, the interaction between CMMI level-5 appraisal and internationalization strategy was statistically significant. It can be deduced that the firms that have been appraised at CMMI level- 5 seem to be making different international location decisions than the firms that have not been appraised at CMMI level-5 for the same internationalization strategy. Indian software firms with CMMI level-5 appraisal show an increased propensity to locate in a developed nation than the firms without CMMI level-5 appraisal when in market-seeking mode. However, as stated in the hypothesis, the effect is not big as firms without CMMI level-5 appraisal have an already high propensity to locate in a developed country for market- 
seeking purpose. When Indian software firms want to follow labor-seeking strategy for a location, those with CMMI level-5 appraisal are more likely to choose developed countries whereas those without such an appraisal are more likely to choose emerging markets. Surprisingly, wage bills of Indian software firms do not affect their international location decisions, despite the fact that the phenomenon of offshore outsourcing has its genesis in the wage differential between developed and developing countries. The wage bill appears to be a resource that makes Indian software firms competitive in the offshore outsourcing industry and helps them gain offshoring projects; it, however, does not impact their international location choices. Since the firms in an industry pay their employees as per prevailing market salary structure, there may not be a big difference in the salary paid by various Indian software firms to their employees so as to cause a differential impact on their location decisions. Similarly, establishing a knowledge sharing database in an Indian software firm does not impact its international location decisions. Indian software firms may have employed some other methods such as job rotation or careful team selection to disseminate effectively an existing set of knowledge about a client or project to another project.

It may be concluded from the study in this dissertation that internationalization strategies of firms impact their location decisions and some firm resources may moderate this relationship, over and above the country-level and firm-level variables already studied in the literature on location decisions of firms. In the context of Indian software firms, it is the international strategy and the interaction between international strategy and CMMI appraisal at level 5 that impact the location decisions, especially in the context of a labor-seeking strategy.The results obtained in the dissertation are in line with those in Makino et. al's (2002) study with Taiwanese sample where they demonstrate the impact of resources and strategies on international location decisions of Taiwanese firms. With these findings, the limitations of the present study and the potential for future research are discussed in the following chapter. 


\section{CHAPTER IX}

\section{LIMITATIONS AND FUTURE RESEARCH}

The dissertation explores the impact of firm's resources and strategies on its international location choices. The data-points for location strategies were collected for each international location decision. However, the data-points for resources could not be collected at the same time when the firm made the international location decisions. The resource data-points could be collected only at the end of each financial year because of paucity of firms' archival resource data at the time of location decisions. Had such data been available, the statistical tests for hypotheses would have been more rigorous. Availability of such a database would have also reduced the HLM design to two levels instead of three levels as is the case in the dissertation.

The limited sample size of the data restricts the statistical power of the results. In hierarchical designs, it is better to have a larger sample size at the firm level. The dissertation data has only 32 Indian IT services firms tracked over 9 years. The 32 Indian IT services firms in the dataset may appear small in number. However, it is noteworthy that only 165 Indian firms from this sector expanded internationally by 2006 (Pradhan, 2007). The sampled 32 firms engage in more than 50\% of IT exports from India (Gopal \& Gao, 2009) and are among the largest IT services companies of India. Future research may collect data from a bigger sample of Indian IT services companies and study their international location decisions. Indian pharmaceutical firms may have also thrived internationally on the basis of their processrelated resources. These firms engage in research and development (R\&D) and a data collected from Indian pharmaceutical firms would have allowed the analysis of the impact of R\&D on international location decisions, as $R \& D$ is considered one of the ownership advantages of multinationals that help them go international (Caves, 1971; Dunning, 1983). The same could not be explored in the context of Indian IT software firms as only a handful of these companies conduct R\&D restricting the dataset to have a proportionately large number of missing values. At the same time, a dataset collected from Indian pharmaceutical companies would have allowed the analysis of location decisions in the context of assetseeking strategy as many Indian pharmaceutical firms have internationalized for asset-seeking purpose. A similar analysis for Indian IT software companies could not be conducted as these firms have not 
internationalized with asset-seeking strategy. It was, however, decided to proceed with Indian IT services companies because these companies have located in many countries (Pradhan, 2007) compared to Indian pharmaceutical firms affording a larger database with more statistical power. Future research may consider data collection from Indian pharmaceutical industry and may analyze the differences, if any, in the international location patterns of the firms possessing similar resource types but coming from different industries.

As only one of the resources namely CMMI level 5 appraisal moderated the relationship between international strategy and location choice, future research is required to validate further the role played by resources in international location decisions of the firms.

The full conceptual model proposed in the dissertation could not be empirically tested at this time, as its empirical test requires a dataset collected from firms having different types of resources defined in the conceptual model. This would have probably required a data collected and compiled from firms based in more than one country. The limited time and other resources available to the author of the dissertation at the time of conducting the dissertation research precluded the author from engaging in full empirical testing of the conceptual model. Hence at this time, with limited resources at disposal, only one string of the full conceptual model is empirically tested in the dissertation. It is acknowledged that an empirical study based on data collected from firms from single country may suffer from low external validity. However, the dissertation is among the few scholarly studies that analyze the international location decisions of emerging market firms. The conceptual model, though, has its settings in emerging markets as it discusses the resources owned by emerging market firms, the broader theoretical argument of the model is equally applicable to the developed country firms which possess a different set of resources.

As a research design, it is better to have an understanding of what kinds of resources helped Indian IT services companies choose each of their international location decisions. Though $81.25 \%$ of 64 interviewees responded that it was the process-related responses that helped their companies locate internationally, some resondents, though fewer in numbers, did indicate that resources other than processrelated ones helped in the internationalization of their firms. This makes it plausible, then, that companies may possess a basket of resources and may choose and utilize the most suitable resource type from this 
basket of resources to launch their operations in different countries. A dataset that compiles which resource type out of the ones proposed in the dissertation helps emerging market firms choose each of their location decisions would provide a more statistically powerful examination of the relationship between resources, strategies, and location decisions. Such a dataset, however, could not be compiled in this dissertation as such historical information could only be obtained with help of interviews at this time as the firms did not possess any archival records of this information. However, such an interview-based dataset may suffer from common-method bias and retrospective response bias. The future research may look into this aspect and compile a dataset over a period of time that simultaneously records the resource type that helps a firm make a particular location decision.

It is plausible that firms, in their location decision matrix, may consider different set of country characteristics as more salient over others for different internationalization strategy. For example, a different set of macroeconomic factors may become more important when firms locate in a country with labor-seeking strategy than when they locate in the same country with other internationalization strategy. Similarly, cultural or geographic distance may impact location decisions when firms follow one type of internationalization strategy over others. Thus, a study looking at the interaction between country characteristics and internationalization strategies may likely throw some interesting findings and may be conducted by future researchers.

Last but not least, the conceptual model can be empirically tested for developed country firms by future scholars. In the following chapter which also happens to be the last chapter of the dissertation, conclusions drawn from the study are discussed. 


\section{CHAPTER X}

\section{CONCLUSION}

Indian software companies are recognized as the most aggressive international investors from India, constituting 30\% of outward FDI from India (Pradhan, 2007). These organizations have expanded overseas on the basis of their process-related resources. Thus, these companies may serve as a laboratory for understanding the location decisions of emerging market firms with process-related resources. The extant literature would approach a study on location decisions by mainly incorporating country characteristics in the statistical model. This dissertation suggests that, over and above the country characteristics, it is the internationalization strategies and interaction between firm resources and its strategies that would predict the location decisions of firms. The empirical results obtained by using multilevel hierarchical model for analyzing the location decisions made by Indian software companies between April 2000 and March 2009 statistically support the model. It seems that Indian software organizations are guided by their internationalization strategies in making location decisions and various kinds of distances do not negatively impact their location decisions. In fact, an increase in cultural distance between India and the host country seems to motivate these companies to go to a distantly located developed country. Hence, the traditional theories in location decision may incorporate the firm's internationalization strategies and the interaction of these strategies with firm resources as two additional predictors in the model aiming to predict the location decisions of the firms.

Indian software firms have located overseas with two internationalization strategies namely market-seeking and labor-seeking strategies. The roles of firm-specific resources such as their wage bills, electronic knowledge sharing database, and CMMI level-5 appraisal was investigated in context of their location decisions. CMMI level-5 appraisal was found to moderate the relationship between firms' strategies and location decisions.

The study carries many managerial implications. First, it suggests a comprehensive model to the managers to steer the international location choices of their firms. The proposed comprehensive model has the potential to overcome the conflicting guidelines offered by the extant literature on location decisions. Moreover, by grounding the dissertation in an emerging market setting, the study makes specific 
recommendations to the managers working with emerging market firms that own a set of resources different from developed country firms. The conceptual model proposed in the dissertation, however, may be applied with equal ease to study the location decisions of developed country firms - just that the model for developed country firms would require the resource box in the model to have developed country firmspecific resources. To the managers working with Indian software firms, it suggests that they try to obtain CMMI level-5 appraisal, if they aim to lead their companies into the league of the largest Indian software companies and aim to compete with large multinational vendor firms from other countries. CMMI level-5 appraisal holds the prospect to steer these firms successfully in (i) tapping bigger potential in developed nations; and (ii) establishing a global delivery center in close vicinity of their customers in developed countries.

Thus, it can be concluded that internationalization strategies predict the location decisions made by firms over and above the factors listed in the extant literature and some firm resources may moderate this relationship. The dissertation demonstrates this with help of hand-collected data from Indian software companies that have been internationalizing rapidly irrespective of the cultural distances between India and the host nations. 


\section{LIST OF REFERENCES}

Acquaah, M., \& Bryan, J.M. 2007. Managerial social capital, strategic orientation, and organizational performance in an emerging economy. Strategic Management Journal, 28: 1235-1255.

Aharonson, B.S., Baum, J.A.C., \& Feldman, M.P. 2007. Desperately seeking spillovers? Increasing returns, industrial organization and the location of new entrants in geographic and technological space. Industrial and Corporate Change, 16(1): 89-130.

Aitken, B., \& Harrison, A. 1999. Do domestic firms benefit from direct foreign investment? Evidence from Venezuela. American Economic Review, 89: 605-618.

Alcacer, J. 2006. Location choice across the value chain: How activity and capability influence collocation. Management Science, 52(10): 1457-1471.

Alcacer, J., \& Chung, W. 2007. Location strategies and knowledge spillovers. Management science, 53(5): 760-776.

Almeida, P. 1996. Knowledge Sourcing by Foreign Multinationals: Patent Citation Analysis in the US Semiconductor Industry. Strategic Management Journal, 17(Winter Special Issue): 155-165.

Almeida, P., \& Phene, A. 2004. Subsidiaries and knowledge creation: The influence of the MNC and host country on innovation. Strategic Management Journal, 25: 847-864.

Almor, T., \& Hashai, N. 2004. The competitive advantage and strategic configuration of knowledgeintensive, small- and medium-sized multinationals: A modified resource-based view. Journal of International Management, 10: 479-500.

Amit, R., \& Schoemaker, P.J.H. 1993. Strategic assets and organizational rent. Strategic Management Journal, 14(1): 33-46.

Anand, J., \& Delios, A. 1997. Location specificity and the transferability of downstream assets to foreign subsidiaries. Journal of International Business Studies, 28(3): 579-603.

Anand, J., \& Delios, A. 2002. Absolute and relative resources as determinants of international acquisitions. Strategic Management Journal, 23: 119-134.

Argyres, N. 1996. Evidence on the role of firm capabilities in vertical integration decisions. Strategic Management Journal, 17: 129-150.

Armstrong, C.E., \& Shimizu, K. 2007. A review of approaches to empirical research on the resource-based view of the firm. Journal of Management, 33(6): 959-986.

Arregle, J-L., Hebert, L., \& Beamish, P.W. 2006. Mode of international entry: The advantages of multilevel methods. Management International Review, 46(5): 597-618.

Aulakh, P.S. 2007. Emerging multinationals from developing economies: Motivations, paths, and performance. Journal of International Management, 13: 235-240.

Aulakh, P.S., \& Kotabe, M. 2008. Institutional changes and organizational transformation in developing economies. Journal of International Management, 14: 209-216.

Aulakh, P.S., Kotabe, M., \& Teegen, H. 2000. Export strategies and performance of firms from emerging economies: evidence from Brazil, Chile, and Mexico. Academy of Management Journal, 43(3): 342-361. 
Aydin, M.N., \& Bakker, M.E. 2008. Analyzing IT maintenance outsourcing decision from a knowledge management perspective. Information Systems Frontiers, 10: 293-305.

Babcock, P. 2004. Shedding light on knowledge management. HR Magazine, 49(5): 46-50.

Banga, R. 2006. The export-diversifying impact of Japanese and US foreign direct investments in the Indian manufacturing sector. Journal of International Business Studies, 37: 558-568.

Barkema, H.G., Bell, J.H., \& Pennings, J.M. 1996. Foreign entry, cultural barriers, and learning. Strategic Management Journal, 17(2): 151-166.

Barkema, H.G., \& Drogendijk, R. 2007. Internationalizing in small, incremental or larger steps? Journal of International Business Studies, 38: 1132-1148.

Barkema, H.G., Shenkar, O., Vermeulen, F., \& Bell, J.H.J. 1997. Working abroad, working with others: How firms learn to oeprate international joint ventures. Academy of Management Journal, 40(2): 426442.

Barney, J.B. 1991. Firm resources and sustained competitive advantage. Journal of Management, 17(1): $99-120$.

Barney, J.B., \& Arikan, A.M. 2001. The resource-based view: Origins and implications. In M.A. Hitt, R.E. Freeman, \& J.S. Harrison (Eds.), Handbook of strategic management: 124-188. Oxford, U.K.: Blackwell.

Bartlett, C.A., \& Ghoshal, S. 1989. Managing across borders: The transnational solution. Boston, MA: Harvard Business School Press.

Baum, J.A.C., \& Haveman, H.A. 1997. Love thy neighbor? Differentiation and agglomeration in the manhattan hotel industry, 1898-1990. Administrative Science Quarterly, 42(2): 304-338.

Baum, J.A.C., Li, S.T., \& Usher, J.M. 2000. Making the next move: How experiential and vicarious learning shape the locations of chains' acquisitions. Administrative Science Quarterly, 45(4): 766-801.

Baum, J.A.C., \& Mezias, S.J. 1992. Localized competition and organizational failure in the Manhattan hotel industry, 1898-1990. Administrative Science Quarterly, 37(4): 580-604.

Bandelj, N. 2002. Embedded economies: Social relations as determinants of foreign direct investment in Central and Eastern Europe. The University of North Carolina Press, 81(2): 411-444.

Beamish, P.W. 1984. Joint venture performance in developing countries. Unpublished Ph.D. dissertation. London, Canada: The University of Western Ontario.

Beckerman, W. 1956. Distance and the pattern of intra-european trade, Review of Economics and Statistics, 71(1): 143-153.

Benito, G.R.G., \& Gripsrud, G. 1992. The expansion of foreign direct investments: Discrete rational location choices or a cultural learning process? Journal of International Business Studies, 23(3): 461476.

Bhardwaj, A., Dietz, J., \& Beamish, P.W. 2007. Host country cultural influences on foreign direct investment. Management International Review, 47(1): 29-50. 
Bianchi, C.C., \& Ostale, E. 2006. Lessons learnt from unsuccessful internationalization attempts: examples of multinational retailers in Chile. Journal of Business Research, 59(1): 140-147.

Black, J.A., \& Boal, K.B. 1994. Strategic resources: Traits, configurations and paths to sustainable competitive advantage. Strategic Management Journal, 15 (Summer Special Issue): 131-148.

Bliese, P.D., Ployhart, R.E. 2002. Growth modeling using random coefficient models: Model building, testing, and illustrations. Organizational Research Methods, 5(4): 362-387.

Bock, G., Zmud, R.W., Kim, Y., \& Lee, J. 2005. Behavioral intention formation in knowledge sharing: Examining the roles of extrinsic motivators, social-psychological forces, and organizational climate. MIS Quarterly, 29: 87-111.

Boddewyn, J.J. 1988. Political aspects of MNE theory. Journal of International Business Studies, 19(3): 341-363.

Boddewyn, J.J. 2003. Understanding and advancing the concept of "nonmarket". Business \& Society, 42(3): 297-327.

Boddewyn, J.J., \& Brewer, T.L. 1994. International-Business political behavior: New theoretical directions. Academy of Management Review, 19(1): 119-143.

Bogner, W.C., Thomas, H., \& McGee, J. 1996. A longitudinal study of the competitive positions and entry paths of European firms in the U.S. pharmaceutical market. Strategic Management Journal, 17: 85-107.

Bogner, W., \& Barr, P. 2000. Making sense in hypercompetitive environments: a cognitive explanation for the persistence of high velocity competition. Organization Science, 11(2): 212-226.

Bonaglia, F., Golstein, A., \& Mathews, J.A. 2007. Accelerated internationalizaiton by emerging markets' multinationals: The case of the white goods sector. Journal of World Business, 42(4): 369-383.

Breschi, S., \& Malerba, F. 2001. The geography of innovation and economic clustering: Some introductory notes. Industrial and Corporate Change, 10(4): 817-833.

Brewer, T.L. 1993. Government policies, market imperfections, and foreign direct investment. Journal of International Business Studies, 24(1): 101-120.

Brouthers, K.D.; Brouthers, L.E., Werner, S. 2008. Resource-based advantages in an international context. Journal of Management, 34(2): 189-217.

Brouthers, L.E. 1998. Explaining MNC profitability: country-specific, industry-specific and countryindustry interactive influences. Management International Review, 38(4): 345-361.

Brouthers, L.E., Gao, Y., \& Mcnicol, J.P. 2008. Corruption and market attractiveness influences on different types of FDI. Strategic Management Journal, 29: 673-680.

Buckley, P. J., \& Casson, M.C. 1976. The future of multinational enterprises. London: Holmes \& Meier.

Buckley, P. J., \& Casson, M.C. 1996. An economic model of intenational joint venture strategy. Journal of International Business Studies, 27(5): 849-876.

Buckley, P. J., Clegg, L.J., Wang, C. 2002. The impact of inward FDI on the performance of Chinese manufacturing firms. Journal of International Business Studies, 33(4): 637-655. 
Buckley, P. J., Clegg, L.J., Cross, A.R., Liu, X., Voss, H., \& Zheng, P. 2007. The determinants of Chinese outward foreign direct investment. Journal of International Business Studies, 38: 499-518.

Buckley, P.J., Devinney, T.M., \& Louviere, J.J. 2007. Do managers behave the way theory suggests? A choice-theoretic examination of foreign direct investment location decision-making. Journal of International Business Studies, 38: 1069-1094.

Buckley, P.J., \& Ghauri, P.N. 2004. Globalization, economic geography, and the strategy of multinational enterprises. Journal of International Business Studies, 35(2): 81-98.

Campbell-Hunt, C. 2000. What have we learned about generic competitive strategy? A meta-analysis. Strategic Management Journal, 21: 127-154.

Canal-Garcia, E., \& Guillen, M.F. 2008. Risk and the strategy of foreign location choice in regulated industries. Strategic Management Journal, 29: 1197-1115.

Cantwell, J.A. 1989. Technological innovation and multinational corporations. Oxford: Basil Blackwell.

Cantwell, J.A. 1995. The globalization of technology: What remains of the product cycle model: Cambridge Journal of Economics, 19(1): 155-174.

Cantwell, J.A. 2009. Location and the Multinational Enterprise. Journal of International Business Studies, 40(1): 35-41.

Cantwell, J.A., Dunning, J.H., \& Janney, O.E.M. 2004. Towards a technology-seeking explanation of U.S. direct investment in the United Kingdom. Journal of International Management, 10: 5-20.

Cantwell, J.A. \& Janney, O.E.M. 1999. Technologies globalization and innovative centers: the role of corporate technological leadership and location hierarchy. Research Policy, 28: 119-144.

Cantwell, J.A., \& Mudambi, R. 2005. MNE competence-creating subsidiary mandates. Strategic Management Journal, 26(12): 1109-1128.

Capelleras, J-L., Mole, K.F., Greene, F.J., \& Storey, D.J. 2008. Do more heavily regulated economies have poorer performing new ventures? Evidence from Britain and Spain. Journal of International Business Studies, 39: 688-704.

Carney, M. 2008. The many futures of Asian business groups. Asia Pacific Journal of Management, 25: 595-613.

Carpenter, M.A., \& Fredrickson, J.W. 2001. Top management teams, global strategic posture, and the moderating role of uncertainty. Academy of Management Journal, 44(3): 533-545.

Caves, R.E. 1971. Industrial Corporations: The industrial economics of foreign investment. Economica, 38: $1-27$.

Chang, S.J., \& Hong, J. 2000. Economic performance of group-affliated companies in Korea: Intragroup resource sharing and internal business transactions. Academy of Management Journal, 43(3): 429-448.

Chacar, A., \& Vissa, J. 2005. Are emerging economies less efficient? Performance persistence and business group affiliation. Strategic Management Journal, 26: 933-946.

Chakrabarti, A., Singh, K., \& Mahmood, I. 2007. Diversification and performance: Evidence from East Asian firms. Strategic Management Journal, 28: 101-120. 
Chan, C.M., Isobe, T., \& Makino, S. 2008. Which country matters? Institutional development and foreign affiliate performance. Strategic Management Journal, 29: 1179-1205.

Chand, S.J., \& Hong, J. 2000. Economic Performance of Group-Affiliated Companies in Korea: Intragroup Resource Sharing and Internal Business Transactions. Academy of Management Journal, 43(3): 429-448.

Chang, S., 2006. Business groups in East-Asia: Post-crisis restructuring and new growth. Asia Pacific Journal of Management, 23: 407-417.

Chang, S., \& Park, S. 2005. Types of firms generating network externalities and MNC's co-location decision. Strategic Management Journal, 26: 595-615.

Chang, S.J., \& Xu, D. 2008. Spillovers and Competition Among Foreign and Local Firms in China. Strategic Management Journal, 29: 495-518.

Chapman, M., Gajewska-De Mattos, H., Clegg, J., \& Buckley, P.J. 2008. Close neighbors and distant friends: Perceptions of cultural distance. International Business Review, 17(3): 217-234.

Chatterjee, S., \& Wernerfelt, B. 1991. The link between resources and the type of diversification: Theory and evidence. Strategic Management Journal, 12: 33-48.

Chen, T. 2003. Netwrok resources for internationalization: The case of Taiwan's electronics firms. Journal of Management Studies, 40(5): 1107-1130.

Chen, H. \& Chen, T.J. 1998. Network linkages and location choice in foreign direct investment. Journal of International Business Studies, 29(3): 445-468.

Chen, T.J., Chen, H., \& Ku,Y.H. 2004. Foreign direct investment and local linkages. Journal of International Business Studies, 35(4): 320-333.

Chen, D., Park, S.H., \& Newburry, W. 2009. Parent contribution and organizational control in international joint ventures. Strategic Management Journal, 30(11): 1133-1156.

Child, J. 1997. Strategic choice in the analysis of action, structure, organizations and environment: Retrospect and prospect. Organization Studies, 18(1): 43-76.

Child, J., Chung, L., \& Davies, H. 2003. Ther performance of cross-border untis in China: A test of natural selection, strategic choce and contingency theories. Journal of International Business Studies, 34: 242254.

Child, J., \& Rodrigues, S.B. 2005. The internationalization of Chinese firms: A case for theoretical expansion?. Management and Organizational Review, 1(3): 381-410.

Child, J., \& Tse, D.K. 2001. China's transition and its implications for international business. Journal of International Business Studies, 32(1): 5-21.

Chittoor, R., \& Ray, S. 2007. Internationalization paths of Indian pharmaceutical firms - A Strategic Group Analysis. Journal of International Management, 13: 338-355.

Chittoor, R., Sarkar, M.B., Ray, S., \& Aulakh, P.S. 2009. Third-world copycats to emerging multinationals: institutional changes and organizational transformation in the Indian pharmaceutical industry.

Organization Science, 20(1): 187-205. 
Choi, J.C., Lee, S.H., \& Kim, J.B. 1999. A note on countertrade: Contractual uncertainty and transaction governance in emerging economies. Journal of International Business Studies, 30(1): 189-201.

Christman, P., Day, D.L., \& Yip, G.S. 1999. The relative influence of country conditions, industry structure, and business strategy on MNC subsidiary performance. Journal of International Management, 5: 241-265.

Chung, W. \& Alcacer, J. 2002. Knowledge seeking and location choice of foreign direct investment in the United States. Management Science, 48(12): 1534-1554.

Chung, W., \& Kalnins, A. 2001. Agglomeration effects and performance: A test of the Texas lodging industry. Strategic Management Journal, 22(10): 969-988.

Coeurderoy, R., \& Murray, G. 2008. Regulatory environments and the location decisions: evidence from the early foreign market entries of new technology-based firms. Journal of International Business Studies, 39: 670-687.

Cordell, V. 1993. Interaction effects of country of origin with braning, price, and perceived performance risk. Journal of International Consumer Marketing, 5(2): 5-20.

Couto, V., Mani, M., Lewin, A., \& Peeters, C. 2006. The globalization of white-collar work. Offshoring Research Network working paper, Duke University-CIBER, Durham, NC.

Craig, C.S., \& Douglas, S.P. 1997. Executive insights: Managing the transnational value chain - Strategies for firms from emerging markets. Journal of International Marketing, 5(3): 71-84.

Crook, T.R., Ketchen Jr., D.J., Combs, J.G., Todd, S.Y. 2008. Strategic resources and performance: A meta-analysis. Strategic Management Journal, 29: 1145-1154.

Cuervo-Cazurra, A. 2006. Who cares about corruption? Journal of International Business Studies, 37: 807822.

Cuervo-Cazurra, A. 2006. Business groups and their types. Asia Pacific Journal of Management, 23: 419437.

Cuervo-Cazurra, A. 2007. Sequence of value-added activities in the multinationalization of developing country firms. Journal of International Management, 13: 258-277.

Cuervo-Cazurra, A. 2008. Better the devil you don't know: Types of corruption and FDI in transition economies. Journal of International Management, 14: 12-27.

Cuervo-Cazurra, A. 2008. The multinationalization of developing country MNEs: The case of multilatinas. Journal of International Management, 14: 138-154.

Cuervo-Cazurra, A., \& Genc, M. 2008. Transforming disadvantages into advantages: Developing-country MNEs in the least developed countries. Journal of International Business Studies, 39: 957-979.

Cuervo-Cazurra, A., Maloney, M.M., Manrakhan, S. 2007. Causes of the difficulties in internationalization. Journal of International Business Studies, 38: 709-725.

Dawar, N., \& Frost, T. 1999. Competing with giants: survival strategies for local companies in emerging markets. Harvard Business Review, 119-129. 
D'Costa, A.P. 2004. The Indian software industry in the global division of labor. In D'Costa, A.P. \& Sridharan, E. (Eds.), India in the global software industry: Innovation, firms strategies and development: 1-26. London: Palgrave McMillan.

Delios, A., \& Beamish, P.W. 2001. Survival and profitability: The roles of experience and intangible assets in foreign subsidiary performance. Academy of Management Journal, 44(5): 1028-1038.

Delios, A., \& Henisz, W.J. 2000. Japanese firms' investment strategies in emerging economics. Academy of Management Journal, 43(3): 305-323.

Delios, A., \& Henisz, W.J. 2003. Policy uncertainty and the sequence of entry by Japanese firms, 19801998. Journal of International Business Studies, 34: 227-241.

Delios, A., \& Henisz, W.J. 2003. Political hazards, experience, and sequential entry strategies: The international expansion of Japanese Firms, 1980-1998. Strategic Management Journal, 24: 1153-1164.

Deng, P. 2003. Foreign investment by multinationals from emerging countries: The case of China. Journal of Leadership and Organizational Studies, 10(2): 113-124.

Dierickx, I., \& Cool, K. 1989. Asset stock accumulation and sustainability of competitive advantage. Management Science, 35: 1504-1511.

DiMaggio, P.J., \& Powell, W.W. 1983. The iron cage revisited: Institutional isomorphism and collective rationality in organizational fields. American Sociological Review, 48(2): 147-160.

Dixit, A. 1989. Hysteresis, import penetration, and exchange rate pass-through. The Quarterly Journal of Economics. 104(2): 205-228.

Doh, J.P. 2005. Offshore outsourcing: Implications for international business and strategic management theory and practice. Journal of Management Studies, 42(3): 695-704.

Doh, J.P., \& Ramamurti, R. 2003. Reassessing risk in developing country infrastructure. Long Range Planning, 36: 337-353.

Donaldson, L. 2001. The contingency theory of organizations. Sage: Thousand Oaks, CA.

Dow, D. 2000. A note on psychological distance and export market selection. Journal of International Marketing, 8(1): 51-64.

Dow, D., \& Karunaratna, A. 2006. Developing a multidimensional instrument to measure psychic distance stimuli. Journal of International Business Studies, 37: 578-602.

Dowell, G., Killaly, B. 2008. Effect of resource variation and firm experience on market entry decisions: Evidence from U.S. telecommunication firms' international expansion decisions. Organization Science, 20(1): 69-84.

Drazin, R., \& Van de ven, A.H. 1985. Alternative forms of fit in contingency theory. Adminstrative Science Quarterly, 30: 514-39.

Dunning, J.H. 1980. Towards an eclectic theory of international production: Some empirical tests. Journal of International Busines Studies, 11(1): 9-31.

Dunning, J.H. 1983. Changes in the structure of international production. The last 100 years. In M.C. Casson, ed., The growth of international business. London: Allen \& Unwin. 
Dunning, J.H. 1988. The eclectic paradigm of international production: A restatement and some possible extensions. Journal of International Business Studies, 19(1): 1-31.

Dunning, J.H. 1995. Reappraising the eclectic paradigm in the age of alliance capitalism. Journal of International Business Studies, 26(3): 461-491.

Dunning, J.H. 1998. Location and the multinational enterprise: A Neglected Factor? Journal of International Business Studies, 29(1): 45-66.

Dunning, J.H. 2000. Regions, globalization, and the knowledge-based economy. Oxford: Oxford University Press.

Dunning, J.H. 2006. Comment on dragon multinationals: New players in $21^{\text {st }}$ century globalization. Asia Pacific Journal of Management, 23: 139-141.

Dunning, J.H. 2009. Location and the Multinational Enterprise: John Dunning's thoughts on receiving the Journal of International Business Studies 2008 decade award. Journal of International Business Studies, 40(1): 20-34.

Dunning, J.H., Fujita, M., \& Yakova, N. 2007. Some macro-data on the regionalisation/globalisation debate: A comment on the Rugman/Verbeke analysis. Journal of International Business Studies, 38: 177199.

Dunning, J.H., \& Lundan, S.M. 2008. Multinational enterprises and the global economy. U.K.: Edward Elgar.

Dyer, J.H., \& Singh, H. 1998. The relational view: cooperative strategy and sources of interorganizational competitive advantage. Academy of Management Review, 23: 660-679.

Economist. India's economy: Too hot to handle, November 25, 2006, pp. 73-74.

Eisenhardt, K.M. \& Schoonhoven, C.B. 1996. Resource-based view of strategic alliance formation: Strategic and social effects in entrepreneurial firms. Organization Science, 7(2): 136-150.

Elango, B., \& Pattnaik, C. 2007. Building capabilities for international operations through networks: A study of Indian firms. Journal of International Business Studies, 38: 541-555.

Ellis, P.D. 2008. Does psychic distance moderate the market size-entry sequence relationship? Journal of International Business Studies, 39: 351-369.

Enders, C.K., \& Tofighi, D. 2007. Centering predictor variables in cross-sectional multilevel models: A new look at an old issue. Pyschological Methods, 12(2): 121-138.

Enright, M.J. 2002. Geographies and international business: a three dimensional approach. Paper delivered at the Academy of International Business Conference, San Juan.

Erramilli, M.K. 1992. The experience factor in foreign market entry behavior of service firms. Journal of International Business Studies, 23(3): 479-501

Erramilli, M.K., Agarwal, S. \& Kim, S., 1997. Are firm-specific advantages location-specific too? Journal of International Business Studies, 28(4): 735-757.

Erramilli, M.K., Srivastava, R., \& Kim, S. 1999. Internationalization theory and Korean multinationals. Asia Pacific Journal of Management, 16: 29-45. 
Fagre, N., \& Wells, L.T. 1982. Bargaining power of multinationals and host governments. Journal of International Business Studies, 13(2): 9-24.

Farashahi, M., \& Hafsi, T. 2009. Strategy of firms in unstable institutional environments. Asia Pacific Journal of Management, 26(4): 643-667.

Fiegenbaum, A., Shaver, J.M., \& Yeung, B. 1997. Which firms expand to the Middle-East: The experience of U.S. multinationals. Strategic Management Journal, 18(2): 141-148.

Filatotchev, I., Buck, T., \& Zhukov, V. 2000. Downsizing in privatized firms in Russia, Ukraine, and Belarus. Academy of Management Journal, 43(3): 286-304.

Filatotchev1, I., Strange1, R., Piesse1, J., \& Lien, Y.C. 2007. FDI by firms from newly industrialized economies in emerging markets: Corporate governance, entry mode and location. Journal of International Business Studies, 38(4): 556-572.

Flores, R.G., \& Aguilera R.V. 2007. Globalization and location choice: An analysis of US multinational firms in 1980 and 2000. Journal of International Business Studies, 38(7): 1187-1210.

Flowers, E.B. 1976. Oligopolistic reactions in European and Canadian direct investment in the United States. Journal of International Business Studies, 7(2): 43-55.

Frost, T.S. 2001. The geographic sources of foreign subsidiaries' innovations. Strategic Management Journal, 22(2): 101-123.

Fulk, J., Heino, R., Flanagin, A.J., Monge, P.R., \& Bar, F. 2004. A test of the individual action model for organizational information commons. Organization Science, 15: 569-585.

Galan, J.I., Gonzalez-Benito, J., \& Zuniga-Vincente, J.A. 2007. Factors determining the location decisions of Spanish MNEs: an analysis based on the investment development path. Journal of International Business Studies. 38: 975-997.

Gavetti, G., \& Rivkin, J.W. 2007. On the origin of strategy: Action and cognition over time. Organization Science, 18(3): 420-439.

Gelbuda, M., Meyer, K.E., Delios, A. 2008. International business and institutional development in central and eastern europe. Journal of Inernational Management, 14(1): 1-11.

Ghemawat, P. 2001. Distance Still Matters: The hard reality of global expansion. Harvard Business Review, 79(8): 137-147.

Ghemawat, P., \& Khanna, T. 1998. The nature of diversified business groups: A research design and two case studies. Journal of Industrial Economics: 46: 35-61.

Ghemawat. P., \& Thomas, C. 2008. Strategic interaction across countries and multinational agglomeration: An application to the cement industry. Management Science, 54(12): 1980-1996.

Gifford, B., \& Kestler, A. 2008. Toward a theory of local legitimacy by MNEs in developing nations: Newmont mining and health sustainable development in Peru. Journal of International Management, 14: 340-352.

Gillespie, K., Riddle, L., Sayre, E., \& Sturges, D. 1999. Diaspora interest in homeland investment. Journal of International Business Studies, 30(3): 623-634. 
Gimeno, J., Hoskisson, R.E., Beal, B.D., \& Wan, W.P. 2005. Explaining the clustering of international expansion moves: A critical test in the U.S. telecommunications industry. Academy of Management Journal, 48(2): 297-319.

Globerman, S., \& Shapiro, D. 2003. Governance infrastructure and US foreign direct investment. Journal of International Business Studies, 34(1): 19-39.

Gomez, H. 1997. The globalization of business in Latin America. International Executive, 39(2): 225-254.

Gopal, A., \& Gao, G. 2009. Certification in the Indian offshore IT services industry. Manufacturing \& Service Operations Management, 2(3): 471-492.

Gopal, A., Mukhopadhyay, T., \& Krishnan, M.S. 2002. The role of software processes and communication in offshore software development. Communications of the ACM, 45(4): 193-200.

Graham, E.M. 1978. Transatlantic investment by multinational firms: A rivalistic phenomenon? Journal of Post Keynesian Economics, 1(1): 82-99.

Grant, R.M. 1991. The resource-based theory of competitive advantage: Implications for strategy formulation. California Management Review, 33(3): 114-135.

Grosse, R., \& Trevino, L.J. 1996. Foreign direct investment in the United States: An analysis by country of origin. Journal of International Business Studies, 27(1): 139-155.

Grosse, R., \& Trevino, L.J. 2005. New institutional economics and FDI location in central and eastern Europe. Management International Review, 45(2): 123-145.

Guillen, M.F. 2000. Business groups in emerging economies: A resource-based view. Academy of Management Journal, 43(4): 362-380.

Guillen, M.F. 2002. Structural intertia, imitation, and foreign expansion: South Korean firms and business groups in China, 1987-95. Academy of Management Journal, 45(3): 509-525.

Hambrick, D.C. 1983. High profit strategies in mature capital goods industries: A contingency approach. Academy of Management Journal, 26: 687-707.

Haveman, H.A., \& Nonnemaker, L. 2000. Competition in multiple geographic markets: The impact on growth and market entry. Administrative Science Quarterly, 45(2): 232-267.

Henisz, W.J. 2000. The institutional environment for multinational investment. Journal of Law Economics \& Organization, 16(2): 334-364.

Henisz, W.J., \& Delios, A. 2001. Uncertainty, imitation, and plant location: Japanese multinational corporations, 1990-1996. Administrative Science Quarterly, 46(3): 443-475.

Henisz, W.J. 2003. The power of the Buckley and Casson thesis: The ability to manage institutional idiosyncrasies. Journal of International Business Studies, 34: 173-184.

Henisz, W.J., \& Macher, J.T. 2004. Firm- and country-level trade-offs and contingencies in the evaluation of foreign investment: The semiconductor industry, 1994-2000. Organization Science, 15(5): 537-554.

Henisz, W.J., \& Zelner, B.A. 2001. The institutional environment for telecommunications investment. Journal of Economics \& Management Strategy, 10(1): 123-147. 
Hennart, J.F., \& Park, Y.R. 1994. Location, governance, and strategic, determinants of Japanese manufacturing investment in the United States. Strategic Management Journal, 15(6): 419-436.

Herbsleb, J., Zubrow, D., Goldenson, D., Hayes, W., \& Paulk, M. 1997. Software quality and the capability maturity model. Communications of the ACM, 40(6): 30-40.

Hillman, A.J. 2005. Politicians on the board of directors: Do connections affect the bottom line? Journal of Management, 31: 464-481.

Hirschman, A.O. 1958. The strategy of economic development. New Haven, CT: Yale University Press.

Hitt, M.A., Ahlstrom, D., Dacin, M.T., Levitas, E., Svobodina, L. 2004. The institutional effects on strategic alliance partner selection in transition economies. Organization Science, 15(2): 173-185.

Hitt, M.A., Beamish, P.W., Jackson, S.E., Mathieu, J.E. 2007. Building theoretical and empirical bridges across levels: multilevel research in management. Academy of Management Journal, 50(6): 1385-1399.

Hitt, M.A., Bierman, L., Shimizu, K., Kochhar, R. 2001. Direct and moderating effects of human capital on strategy and performance in professional service firms: A resource-based perspective. Academy of Management Journal, 44(1): 13-28.

Hitt, M.A., Bierman, L., Uhlenbruck, K., \& Shimizu, K. 2006. The importance of resources in the internationalization of professional service firms: The good, the bad, and the ugly. Academy of Management Journal, 49(6): 1137-1157.

Hitt, M.A., Hoskission, R.E., \& Kim, H. 1997. International diversification: Effects on innovation and firm performance in product-diversified firms. Academy of Management Journal, 40: 767-777.

Hitt, M.A., Tihanyi, L., Miller, T., \& Connelly, B. 2006. International diversification: Antecedents, outcomes, and moderators. Journal of Management, 32(6): 831-867.

Hoffmann, W.H. 2007. Strategies for managing a portfolio of alliances. Strategic Management Journal, 28: 827-856.

Hofstede, G. 2007. Asian management in the $21^{\text {st }}$ century. Asia Pacific Journal of Management, 24: 411420.

Holcomb, T.R., \& Hitt, M.A. 2007. Toward a model of strategic outsourcing. Journal of Operations Management, 25: 464-481.

Hong, J.F. 2004. Knowledge sharing review. Management Learning, 35(1): 78-82.

Hooley, G., Cox, T., Shipley, D., Fahy, J., Beracs, J., \& Kolos, K. 1996. Foreign direct investment in Hungary: Resource acquisition and domestic competitive advantage. Journal of International Business Studies, 27(4): 683-709.

Hoskisson, R.E., Eden, L., Lau, C.M., \& Wright, M. 2000. Strategy in emerging economies. Academy of Management Journal, 43(3): 249-267.

Hoskisson, R.E., Johnson, R.A., Tihanti, L., \& White, R.E. 2005. Diversified business groups and corporate refocusing in emerging economies. Journal of Management, 31(6): 941-965. 
Hsieh, M.H., Tsai, K.H., \& Hultink, E.J. 2006. The relationships between resource configurations and launch strategies in Taiwan's IC design industry: An exploratory study. Journal of Product Innovation Management, 23(3): 259-273.

Hsing, Y. 1996. Blood, thicker than water: Interpersonal relations and Taiwanese investment in Southern China. Environment and Planning, 28(12): 2241-2261.

Huchzermeier, A., \& Cohen, M.A. 1996. Valuing operational flexibility under exchange rate risk. Oeprations Research, 44(1): 100-113.

Husted, B.W. 1999. Wealth, culture, and corruption. Journal of International Business Studies, 30(2): 339360.

Hutzschenreuter, T., Pedersen, T., \& Volberda, H.W. 2007. The role of path dependency and managerial intentionality: A perspective on international business research. Journal of International Business Studies, 38: 1055-1068.

Hutzschenreuter, T., \& Voll, J.C. 2008. Performance Effects of "Added Ciltural Distance" In the Path of International Expansion: The Case of German Multinational Enterprises. Journal of International Business Studies, 39: 53-70.

Hymer, S.H. 1976. The international operations of national firms: A study of foreign direct investment. Cambridge, MA: MIT Press.

Itaki, M. 1991. A critical assessment of the eclectic theory of the multinational enterprise. Journal of International Business Studies, 22(3): 445-460.

Ito,K., \& Rose, E.L. 2002. Foreign direct investment location strategies in the tire industry. Journal of International Business Studies, 33(3): 593-602.

Jacobides, M.G., \& Lorin, M.H. 2005. Losing sight of the forest for the trees? Productive capabilities and gains from trade as drivers of vertical scope. Strategic Management Journal, 26: 1209-1227.

Jaffe, A.B., Trajtenberg, M., \& Hendersen, R. 1993. Geographic localization of knowledge spillovers as evidenced by patent citations. The Quarterly Journal of Economics, 108(3): 577-598.

Jansson, H., \& Sandberg, S. 2008. Internationalization of small and medium sized enterprises in the Baltic Sea region. Journal of International Management, 14: 65-77.

Johanson, J \& Vahlne H. 1990. The mechanism of internationalisation. International Marketing Review, 7(4): $12-24$.

Johanson, J., \& Vahlne, J.E. 1977. The internationalization process of the firm - A model of knowledge development and increasing foreign market commitments. Journal of International Business Studies, $8(1): 23-32$.

Johanson, J., \& Weidersheim-Paul, F. 1975. The internationalization of firm - Four Swedish cases. Journal of Management Studies, 12: 305-322.

Kapur, D., \& Ramamurti, R. 2001. India's emerging competitive advantage in services. Academy of Management Executive, 15(2): 20-32. 
Karhunen, P., Lofgren, J., \& Kosonen, R. 2008. Revisiting the relationship between ownership and control in international business operations: Lessons from transition economies. Journal of International Management, 14: 78-88.

Kaufmann, D., Kraay, A., \& Zoido-Lobaton, P. 1999. Aggregating Governance Indicators, World Bank, Working Paper no. 2195.

Kedia, B.L., Mukherjee, D., \& Lahiri, S. 2006. Indian business groups: evolution and transformation. Asia Pacific Journal of Management, 23: 559-577.

Khanna, T., \& Palepu, K. 1997. Why focused strategies may be wrong for emerging markets. Harvard Business Review, 75: 41.

Khanna, T., \& Palepu, K. 2000. The future of business groups in emerging markets: Long-run evidence from Chile. Academy of Management Journal, 43(3): 268-285.

Khanna, T., \& Rivkin, J.W. 2006. Interorganizational ties and business group boundaries: Evidence from an emerging economy. Organization Science, 17(3): 333-352.

Khanna, T., \& Yafeh, Y. 2005. Business groups and risk sharing around the world. Journal of Business, 78(1): 301-340.

Kim, H.Y. 2005. The locational and functional behavior of U.S. autoparts suppliers. Small Business Economics, 24: 79-95.

Kimura, Y., \& Lee, H.K. 1998. Korean direct investment in manufacturing: its patterns and determinants an empirical analysis. Journal of International Management, 4(2): 109-127.

Klein, S., \& Wocke, A. 2007. Emerging global contenders: The South African experience. Journal of International Management, 13: 319-337.

Knickerbocker, F.T. 1973. Oligopolistic reaction and multinational enterprise. Division of research, Graduate School of Business Administration, Harvard University. Boston: Harvard Business School Press.

Kobrin, S.J., Basek, J., Blank, S., \& Palombara, J.L. 1980. The environmental determinants of foreign direct manufacturing investment: An ex post empirical analysis. Journal of International Business Studies, 11(1): 32-47.

Kogut, B. \& Singh, H. 1988. The effect of national culture on the choice of entry mode. Journal of International Business Studies, 19(3): 411-432.

Kogut, B., \& Chang, S.J. 1996. Platform investments and volatile exchange rates: direct investment in the U.S. by Japanese electronic companies. The Review of Economics and Statistics, 78(2): 221-231.

Kostova, T. 1999. Transnational transfer of strategic organizational practices: A contextual perspective. Academy of Management Review, 24(2): 308-324.

Kostova, T., \& Zaheer, S. 1999. Organizational legitimacy under conditions of complexity: The case of the multinational enterprise. Academy of Management Review, 24(1): 64-81.

Kostova, T., Roth, K., \& Dacin, T. 2008. Institutional theory in the study of MNCs: A critique and new directions. Academy of Management Review, 33(4): 994-1006. 
Kotha, S., Rindova, V.P., \& Rothaermel, F.T. 2001. Assets and actions: Firm-specific factors in the internationalization of U.S. internet firms. Journal of International Business Studies, 32(4): 769-791.

Kraatz, M.S., \& Zajac, E.J. 2001. How organizational resources affect strategic change and performance in turbulent environments: Theory and evidence. Organization Science, 12(5): 632-657.

Krugman, P. 1991. Increasing returns and economic geography. Journal of Political Economy, 99: 383397.

Kshetri, N., \& Ajami, R., 2008. Institutional reforms in the Gulf cooperation council economies: A conceptual framework. Journal of International Management, 14: 300-318.

Kumar, K. \& McLeod, M.G. (eds.). 1981. Multiantional from developing countries. Lexington, Lexington Books.

Kumar, N. 1994. Determinants of export orientation of foreign production by U.S. multinationals: An intercountry analysis. Journal of International Business Studies, 25(1): 141-156.

Kuemmerle, W. 1999. The drivers of foreign direct investment into research and development: An empirical investigation. Journal of Intenational Business Studies. 30(1): 1-24.

Kundu, S.K., \& Contractor, F.J. 1999. Country location choices of service multinationals: An empirical study of the international hotel sector. Journal of International Management, 5(4): 241-319.

Lall, S. 1983. The new multinationals: The spread of third-world multinationals. New-York: John Wiley.

La Porta, R., Lopez-de-Silanes, F., Shleifer, A., \& Vishny, R. 1998. Legal determinants of external finance. Journal of Political Economy, 106: 1113-1155.

Lawrence, P.R. \& Lorsch, J.W. 1967. Organization and environment. Boston: Harvard Business School Press.

Lecraw, D.J. 1983. Performance of transnational corporations in less developed countries. Journal of International Business Studies, 14(1): 15-34.

Lecraw, D.J. 1986. Bargaining power, ownership, and profitability of transnational corporations in developing countries. Journal of International Business Studies, 15(1): 27-43.

Lecraw, D.J. 1993. Outward direct investment by Indonesian firms: Motivation and effects. Journal of International Business Studies, 24(3): 589-600.

Lee, C., \& Beamish, P.W. 1995. The characteristics and performance of Korean joint ventures in LDCs. Journal of International Business Studies, 26(3): 637-654.

Lee, J-R., Chen, W-R., \& Kao, C. 1998. Bargaining power and the trade-off between the ownership and control of international joint ventures in China. Journal of International Management, 4(4): 353-385.

Lee, J., \& Slater, J. 2007. Dynamic capabilities, entrepreneurial rent-seeking and the investment development path: the case of Samsung. Journal of International Management, 13:241-257.

Leff, N. 1978. Industrial organization and entrepreneurship in the developing countries: The economic group. Economic Development and Cultural Change, 26: 661-675. 
Lepak, D.P., \& Snell, S.A. 1999. The human resource architecture: Toward a theory of human capital allocation and development. Academy of Management Review, 24(1): 31-48.

Levitt, B., \& March, J.G. 1988. Organizational learning. Annual Review of Sociology. 14: 319-340.

Li, L., Lin, Z., \& Arya, B. 2008. The turtle-hare race story revisited: Social capital and resource accumulation of firms from emerging economies. Asia Pacific Journal of Management, 25: 251-275.

Li, P.P. 2007. Toward an integrated theory of multinational evolution: The evidence of chinese multinational enterprises as latecomers. Journal of International Management, 13:296-318.

Li, S. 2004. Location and performance of foreign firms in China. Management International Review, 44(2):151-169.

Li, H., \& Zhang, Y. 2007. The role of managers' political networking and functional experience in new venture performance: evidence from China's transition economy. Strategic Management Journal, 28:791-804.

Li, J., \& Guisinger, S. 1992. The globalization of service multinationals in the "triad" regions: Japan, Western Europe And North America. Journal of International Business Studies, 23(4): 675-696.

Li, J.J., Poppo, L., \& Zhou, K.Z. 2008. Do managerial ties in China always produce value? Competition, uncertaintym and domestic vs. foreign firms. Strategic Management Journal, 29: 383-400.

Li, J.J., Zhou, K.Z., \& Shao, A.T. 2009. Competitive position, managerial ties, and profitability of foreign firms in China: an interactive perspective. Journal of International Business Studies, 40(2): 339-352.

Liu, C.Z. 2007. Lenovo: An example of globalization of Chinese enterprises. Journal of International Business Studies, 38(4): 573-577.

Liu, H., \& Li, K. 2002. Strategic implications of emerging Chinese multinationals: The Haier case study. European Management Journal, 20(6): 699-706.

London, T., \& Hart, S.L. 2004. Reinventing strategies for emerging markets: Beyond the transnational model. Journal of International Business Studies, 35(5): 350-370.

Loree, D.W., \& Guisinger, S.E. 1995. Policy and non-policy determinants of U.S. equity foreign direct investment. Journal of International Business Studies, 26(2): 281-299.

Lu, J.W., \& Ma, X. 2008. The contingent value of local partners' business group affiliation. Academy of Management Journal, 51(2): 295-314.

Luo, Y. 2001. Determinants of local responsiveness: Perspectives from foreign subsidiaries in an emerging market. Journal of Management, 27: 451-477.

Luo, Y. 2002. Capability exploitation and building in a foreign market: Implications for multinational enterprises. Organization Science, 13(1): 48-63.

Luo, Y. 2002. Corruption and organization in Asian management systems. Asia Pacific Journal of Management, 19: 405-422.

Luo, Y., \& Park, S.H. 2001. Strategic alignment and performance of market-seeking MNCs in China. Strategic Management Journal, 22: 141-155. 
Luo, Y., \& Peng, M.W. 1999. Learning to compete in a transition economy: Experience, environment, and performance. Journal of International Business Studies, 30(2): 269-296.

Luo, Y., \& Tan, J.J. 1998. A comparison of multinational and domestic firms in an emerging market: A strategic choice perspective. Journal of International Management, 4(1): 21-40.

Luo, Y., \& Tung, R.L. 2007. International expansion of emerging market enterprises: A springboard perspective. Journal of International Business Studies, 38(4): 481-498.

MacCarthy, B.L., \& Atthirawong, W. 2003. Factors affecting location decisions in international operations: A Delphi study. International Journal of Operations \& Production Management, 23(7/8): 794-818.

Majchrzak, A., Rice, R.E., King, N., Malhotra, A., \& Ba, S. 2000. Computer-controlled inter-organizational knowledge-sharing: Insights from a virtual team innovating using a collaborative tool. Information Resources Management Journal, 13: 44-53.

Makhija, M.V. 1993. Government intervention in the Venezuelan petroleum industry: An empirical investigation of political risk. 24: 531-555.

Makhija, M.V. 2004. The value of restructuring in emerging economies: The case of the Czech Republic. Strategic Management Journal, 25: 243-267.

Makino, S., Beamish, P.W., \& Zhao, N.B. 2004. The characteristics and performance of Japanese FDI in less developed and developed countries. Journal of World Business, 39: 377-392.

Makino, S., Chan, C.M., Isobe, T., \& Beamish, P.W. 2007. Intended and unintended termination of international joint ventures. Strategic Management Journal, 28: 1113-1132.

Makino, S., \& Delios, A. 1996. Local knowledge transfer and performance: Implications for alliance formation in Asia. Journal of International Business Studies. 27(5): 905-927.

Makino, S., Isobe, T., \& Chan, C.M. 2004. Does country matter? Strategic Management Journal, 25: 10271043.

Makino, S., Lau, C.M., \& Yeh, R.S. 2002. Asset - exploitation versus asset - seeking: implications for location choice of foreign direct investment from newly industrialized economies. Journal of International Business Studies, 33(3): 403-421.

Malik, O.R. 2008. Adapting to market liberalization: The role of dynamic capabilities, initial resource conditions, and strategic path choices in determining evolutionary fitness of less developed country (LDC) firms. Journal of International Management, 14: 217-231.

Markides, C.C., \& Williamson, P.J. 1996. Corporate diversification and organizational structure: A resource-based view. Academy of Management Journal, 39(2): 340-367.

Mathews, J.A. 2002. Competitive advantages of latecomer firm: A resource-based account of industrial catch-up strategies. Asia Pacific Journal of Management, 19(4): 467-488.

Mathews, J.A. 2006. Dragon multinationals: New players in $21^{\text {st }}$ century globalization. Asia Pacific Journal of Management, 23: 5-27.

May, R.C., Stewart, W.H., \& Sweo, R. 2000. Environmental scanning behavior in a transitional economy: Evidence from Russia. Academy of Management Journal, 43(3): 403-427. 
Mariotti, S., \& Piscitello, L. 1995. Information costs and location of FDIs within the host country: Empirical evidence from Italy. Journal of International Business Studies, 26(4): 815-841.

Marshall, A. 1920. Principles of economics. London: Macmillan.

Martin, K.D., Cullen, J.B., Johnson, J.L., \& Parboteeah, K.P. 2007. Deciding to bribe: A cross-level analysis of firm and home country influences on bribery activity. Academy of Management Journal, 50(6): 1401-1422.

Martin, X., \& Salomon, R. 2003. Tacitness, learning, and international expansion: A study of foreign direct investment in a knowledge-intensive industry. Organization Science, 14(3): 297-311.

Martin, X., Swaminathan, A., \& Mitchell, W. 1998. Organizational evolution in the interorganizational environment: Incentives and constraints on international expansion strategy. Administrative Science Quarterly, 43(3): 566-601.

McCann, B.T., \& Folta, T.B. 2008. Location matters: Where we have been and where we might go in agglomeration research. Journal of Management, 34(3): 532-565.

Mesquita, L.F., \& Lazzarini, S.G. 2008. Horizontal and vertical relationships in developing economies: implications for SMEs' access to global markets. Academy of Management Journal, 51(2): 359-380.

Meyer, K.E. 1998. Direct investment in economies in transition. Cheltenham, UK: Edward Elgar.

Meyer, K.E. 2004. Perspectives on multinational enterprises in emerging economies. Journal of International Business Studies, 35(4): 259-276.

Meyer, K.E., Estrin, S., Bhaumik, S.K., \& Peng, M.W. 2009. Institutions, resources, and entry strategies in emerging economies. Strategic Management Journal, 30: 61-80.

Meyer, K.E., \& Nguyen, H.V. 2005. Foreign investment strategies and sub-national institutions in emerging markets: Evidence from Vietnam. Journal of Management Studies, 42(1): 63-93.

Miles, R.E., \& Snow, C.C. 1978. Organizational strategy, structure, and process. New York: Mc-GrawHill.

Miller, D. 1981. Toward new contingency approach: The search for organizational gestalts. Journal of Management Studies, 18: 1-26.

Miller, D. 1988. Relating Porter's business strategies to environment and structure. Academy of Management Journal, 31: 280-308.

Miller, D. 2003. An asymmetry-based view of advantage: towards an attainable sustainability. Strategic Management Journal, 24(10): 961-976.

Miller, D., \& Shamsie, J. 1996. The resource-based view of the firm in two environments: The Hollywood film studios from 1936 to 1965. Academy of Management Journal, 39(3): 519-543.

Miller, S.R., \& Parkhe, A. 1998. Patterns in the expansion of U.S. Banks' foreign operations. Journal of International Business Studies, 29(2): 359-390.

Milliken, F.J., Morrison, E.W., \& Hewlin, P.F. 2003. An exploratory study of employee silence: Issues that employees don't communicate upward and why. Journal of Management Studies, 40(6): 1453-1476. 
Minder, R. Indian wage rises forecast to continue, Financial Times, June 11, 2008, p. 8.

Miranda, S.M., \& Kavan, B.C. 2005. Moments of governance in IS outsourcing: conceptualizing effects of contracts on value capture and creation. Journal of Information Technology. 20: 152-169.

Morck, R., Yeung, B., \& Zhao, M. 2008. Perspectives on China's outward foreign direct investment. Journal of International Business Studies, 39(3): 337-350.

Mudambi, R., \& Navarra, P. 2003. Political tradition, political risk and foreign direct investment in Italy. Management International Review, 43: 247-265.

Mudambi, R. 1998. The role of duration in multinational investment strategies. Journal of International Business Studies, 29(2): 239-262.

Mudambi, R. 2008. Location, control and innovation in knowledge-intensive industries. Journal of Economic Geography, 8(5): 699-725.

Nachum, L. 2000. Economic geography and the location of TNCs: Financial and professional service FDI to the USA. Journal of International Business Studies, 31(3): 367-385.

Nachum, L., \& Wymbus, C. 2005. Product differentiation, external economies and MNE location choices: M\&As in global cities. Journal of International Business Studies, 36(4): 415-434.

Nachum, L., \& Zaheer, S. 2005. The persistence of distance? The impact of technology on MNE motivations for foreign investment. Strategic Management Journal, 26: 747-767.

Nachum, L., Zaheer, S., \& Gross, S. 2008. Does it matter where countries are? Proximity to knowledge, markets and resources, and MNE location choices. Management Science, 54(7): 1252-1265.

Narula, R., \& Dunning, H. 2000. Industrial development and multinational enterprises: new realities for developing countries. Oxford Development Studies, 28(2): 141-167.

Newman, K. 2000. Organizational transformation during institutional upheaval. Academy of Management Review, 25: 602-619.

Newbert, S.L. 2007. Empirical research on the resource-based view of the firm: An assessment and suggestions for future research. Strategic Management Journal. 28: 121-146.

Nigh, D. 1985. The effect of political events on united states direct foreign investment: A pooled timeseries cross-sectional analysis. Journal of International Business Studies, 16(1): 1-17.

Noda, T., \& Bower, J.L. 1996. Strategy making as iterated processes of resource allocation. Strategic Management Journal, 17: 159-192.

Nonaka, I. 1994. A dynamic theory of organizational knowledge creation. Organization Science, 5(1): 1437.

North, D.C. 1990. Institutions, institutional change and economic performance. Cambridge: Cambridge University Press.

O'Grady, S., \& Lane, H.W. 1996. The psychic distance paradox. Journal of International Business Studies, 27(2): 309-333. 
Oliver, C. 1991. Strategic responses to institutional processes. Academy of Management Review, 16(1): 145-159.

Oliver, C. 1997. Sustainable competitive advantage: Combining institutional and resource-based views. Strategic Management Journal, 18(9): 697-713.

Orr, R.J., \& Scott, W.R. 2008. Institutional exceptions on global projects: A process model. Journal of International Business Studies, 39(4): 562-588.

Pan, Y., \& Chi, P.S.K. 1999. Financial performance and survival of multinational corporations in China. Strategic Management Journal, 20: 359-374.

Pananond, P. 2001. The making of Thai multinationals: A comparative study of Thailand's CP and Siam Cement groups. Journal of Asian Business, 17(3): 41-70.

Pananond, P. 2007. The changing dynamics of Thai multinationals after the Asian economic crisis. Journal of International Management, 13: 356-375.

Pantzalis, C. 2001. Does location matter? An empirical analysis of geographic scope and MNC market valuation. Journal of International Business Studies, 32(1): 133-155.

Papadakis, V.M., Lioukas, S, \& Chambers, D. 1998. Strategic decision-making processes: The role of management and context. Strategic Management Journal, 19: 115-147.

Park, S.H., Chen, R. \& Gallagher, S. 2002. Firm resources as moderators of the relationship between market growth and strategic alliances in semiconductor start-ups. Academy of Management Journal, 45(3): 527-545.

Park, S.H., \& Luo, L. 2001. Guanxi and organizational dynalics: Organizational networking in Chinese firms. Strategic Management Journal, 22: 455-477.

Peng, M.W. 2001. Resource-based view and international business. Journal of Management, 27: 803-829.

Peng, M.W. 2003. Institutional transitions and strategic choices, Academy of Management Review, 28(2): 275-296.

Peng, M.W., \& Luo, Y. 2000. Managerial ties and firm performance in a transition economy: The nature of a micro-macro link. Academy of Management Journal, 43(3): 486-501.

Peng, M.W., \& Heath, P.S. 1996. The growth of the firm in planned economies in transition: Institutions, organizations, and strategic choice. Academy of Management Review, 21(2): 492-528.

Perez-Batres, L.A., \& Eden, L. 2008. Is there a liability of localness? How emerging market firms respond to regulatory punctuations. Journal of International Management, 14: 232-251.

Peteraf, M.A. 1993. The cornerstones of competitive advantage: A resource-based view. Strategic Management Journal, 14(3): 179-192.

Petersen, B., \& Pedersen, T. 1999. Fast and slow resource commitment to foreign markets: What causes the difference? Journal of International Management, 5(2): 73-91.

Petersen, B., Pedersen, T., \& Lyles, M.A. 2008. Closing knowledge gaps in foreign markets. Journal of International Business Studies, 39(7): 1097-1114. 
Petrou, A. 2007. Multinational banks from developing versus developed countries: Competing in the same arena? Journal of International Management, 13: 376-397.

Phene, A. \& Paul, A. 2008. Innovation in multinational subsidiaries: The role of knowledge assimilation and subsidiary capabilities. Journal of International Business Studies, 39(5): 901-919.

Porter, M.E. 1980. Competitive strategy. New York: Free Press.

Porter, M.E. 1985. Competitive advantage. New York: Free Press.

Porter, M.E. 1990. The competitive advantage of nations. New York: Free Press.

Porter, M.E. 1994. The role of location in competition. Journal of the Economics of Business, 1(1): 35-39.

Porter, M.E. 2000. Location, competition, and economic development: Local clusters in a global economy. Economic Development Quarterly, 14(1): 15-34.

Pradhan, J.P. 2005. Outward foreign direct investment from India: Recent trends and patterns. GIDR working paper, No. 153.

Pradhan, J.P. 2007. National innovation system and the mergence of Indian information and software technology multinationals. Munich Personal RePEc Archive, Paper No. 12359. 11:31.

Prahalad, C.K. \& Hamel, G. 1990. The core competence of the corporation. Harvard Business Review, 7991.

Priem, R.L., \& Butler, J.E. 2001. Is the resource-based "view" a useful perspective for strategic management research? Academy of Management Journal, 26(1): 22-40.

Pusterla, F., \& Resmini, L. 2007. Where do foreign firms locate in transition countries? An empirical investigation. Annual Regional Science, 41: 835-856.

Ramamurti, R. 2004. Developing Countries and MNEs: Extending and enriching the research agenda. Journal of International Business Studies, 35: 277-283.

Raudenbush, S.W., \& Bryk, A.S. 2002. Hierarchical linear models. Applications and data analysis methods. ( $2^{\text {nd }}$ ed.). London: Sage Publications.

Ricart, J.E., Enright. M.J., Ghemawat, P., Hart, S., \& Khanna, T. 2004. New frontiers in international Strategy. Journal of International Business Studies, 35(3): 175-200.

Rodriguez, P., Uhlenbruck, K., \& Eden, L. 2005. Government corruption and the entry strategies of multinationals. Academy of Management Review, 30(2): 383-396.

Root, F.R., \& Ahmed, A.A. 1978. The influence of policy instruments on manufacturing direct investment in developing countries. Journal of International Business Studies, 9(3): 81-93.

Rose, E.L., \& Ito, K. 2008. Competitive Interactions: The International Investment Patterns of Japanese Automobile Manufacturers. Journal of International Business Studies, 39(5): 864-879.

Rothaermel, F.T., Kotha, S., \& Steensma, H.K. 2006. International market entry by U.S. internet firms: An empirical analysis of country risk, national culture, and market size. Journal of Management, 32(1): 5682. 
Rugman, A., 1979. International diversification and the multinational enterprise. Lexington, MA: Lexington Books.

Rugman, A.M., \& Verbeke, A. 1992. A note on the transnational solution and the transaction cost theory of multinational strategic management. Journal of International Business Studies, 23(4): 761-771.

Rugman, A.M., \& Verbeke, A. 2004. A perspective on regional and global strategies of multinational enterprises. Journal of International Business Studies, 35(1): 3-18.

Sambharya, R.B. 1996. Foreign experience of top management teams and international diversification strategies of U.S. multinational corporations. Strategic Management Journal, 17: 739-746.

Saxenian, A.L., 1996. Regional advantage: culture and competition in silicon valley and route 128. MA: Harvard University Press.

Scheiber, N. 2004. As a center of outsourcing, India could be losing its edge. New York Times, 9 May, 3.

Schoenecker, T.S. \& Cooper, A.C. 1998. The role of firm resources and organizational attributes in determining entry timing: A cross-industry study. Strategic Management Journal, 19: 1127-1143.

Sethi, D., Guisinger, S.E., Phelan, S.E., \& Berg, D.M. 2003. Trends in Foreign Direct Investment Flows: A Theoretical and Empirical Analysis. Journal of International Business Studies, 34(4): 315-326.

Shaver, J.M., \& Flyer, F. 2000. Agglomeration Economies, Firm Heterogeneity, and Foreign Direct Investment In The United States. Strategic Management Journal, 21: 1175-1193.

Shaver, J.M., Mitchell, W., \& Yeung, B. 1997. The effect of own-firm and other-firm experience on foreign direct investment survival in the United States, 1987-92. Strategic Management Journal, 18: 811824.

Shenkar, O. 2001. Cultural Distance Revisited: Towards a more rigorous conceptualization and measurement of cultural differences. Journal of International Business Studies, 32(3):519-535.

Shenkar, O., \& Von-Glinow, M.A.1994. Paradoxes of organizational theory and research: Using the case of China to illustrate national contingency. Management Science, 40(1):56-71.

Smith, D., \& Florida, R. 1994. Agglomeration and industry location: An econometric analysis of Japaneseaffiliated manufacturing establishments in automotive related industries. Journal of Urban Economics. 36: $23-41$

Snijders, T., \& Bosker, R. 1999. Multilevel analysis. An introduction to basic and advanced multilevel modeling. London: Thousand Oaks.

Sol, P.D., \& Kogan, J. 2007. Regional competitive advantage based on pioneering economic reforms: The case of Chilean FDI. Journal of International Business Studies, 38(6): 901-927.

Song, J. 2002. Firm Capabilities and Technology Ladders: Sequential foreign direct investments of Japanese electronics firms in East Asia. Strategic Management Journal, 23(3):191-210.

Soulsby, A. \& Clark, E. 1996. The emergence of post-communist management in the Czech republic. Organization Studies, 17(2): 227-247.

Stare, M. 2002. The pattern of internationalization of services in Central European countries. The Service Industries Journal, 22(1):77-91. 
Steensma, H.K., \& Lyles, M.A. 2000. Explaining IJV survival in a transitional economy through social exchange and knowledge-based perspectives. Strategic Management Journal, 21: 831-851.

Steensma, H.K., Tihanyi, L., Lyles, M., \& Dhanaraj, C. 2005. The evolving value of foreign partnerships in transitioning economies. Academy of Management Journal, 48(2): 213-235.

Suchman, M.C. 1995. Managing legitimacy: Strategic and institutional approaches. Academy of Management Review, 20: 571-610.

Suhomlinova, O. 2006. Toward a model of organizational co-evolution in transition economies. Journal of Management Studies, 43(7): 1537-1558.

Swamidass, P., \& Kotabe, M. 1992. Component sourcing strategies of multinationals: An empirical study of European and Japanese multinationals. Journal of International Business Studies, 23(1): 81-99.

Tabachnik, B.G., \& Fidell, L.S. 2007. Using multivariate statistics $\left(5^{\text {th }}\right.$ ed.). Boston: Pearson.

Tallman, S.B. 1988. Home country political risk and foreign direct investment in The United States. Journal of International Business Studies, 19(2): 219-234.

Tallman, S.B. 1991. Strategic management models and resource-based strategies among MNEs in a host market. Strategic Management Journal, 12 (special issue): 69-82.

Tallman, S.B., Jenkins, M., Henry, N., \& Pinch, S. 2004. Knowledge, clusters, and competitive advantage. Academy of Management Review, 29(2): 258-271.

Tan, J.J., \& Litschert. 1994. Environmental-strategy relationship and its performance implications: An empirical study of the Chinese electronics industry. Strategic Management Journal, 15: 1-20.

Teece, D.J. 1977. Technology transfer by multinational firms: The resource cost of transferring technological know-how. Economic Journal, 87: 242-261.

Teece, D.J., Pisano, G., \& Shuen, A. 1997. Dynamic capabilities and strategic management. Strategic Management Journal, 18(7): 509-533.

Terlaak, A., King, A.A., 2006. The effect of certification with the ISO 9000 quality management standard: A signaling approach. Journal of Economic Behavior \& Organization, 60(4): 579-602.

Terpstra, V., \& Yu, C.M. 1988. Determinants of foreign investment of U.S. advertising agencies. Journal of International Business Studies, 19(1): 33-46.

Thomas, D.E., \& Grosse, R. 2001. Country-of-origin determinants of foreign direct investment in an emerging market: the case of Mexico. Journal of International Management, 7(1): 59-79.

Tian, X. 2007. Accounting for sources of FDI technology spillovers: evidence from China. Journal of International Business Studies, 38(1): 147-159.

Tihanyi, L., Ellstrand, A.E., Daily, C.M., \& Dalton, D.R. 2000. Composition of the top management team and firm international diversification. Journal of Management, 26(6): 1157-1177.

Tihanyi, L., Griffith, D.A., \& Russell, C.J. 2005. The effect of cultural distance on entry mode choice, international diversification and MNE performance: a meta-analysis. Journal of International Business Studies, 36(3): 270-283. 
Tolentino, P.E.E. 1993. Technological innovation and third world multinationals. London: Routledge.

Tong, T.W., Alessandri, T.M., Reuer, J.J., \& Chintakananda, A. 2008. How much does country matter? An analysis of firms' growth options. Journal of International Business Studies, 39(3): 387-405.

Toulan, O.N. 2002. The impact of market liberalization on vertical scope: The case of Argentina. Strategic Management Journal, 23: 551-560.

Trevino, L.J., Mixon, F.G. 2004. Strategic factors affecting foreign direct investments by multinational enterprises in Latin America. Journal of World Business, 39(3): 233-243.

Tsang, E.W., \& Yip, P.S.L. 2007. Economic distance and the survival of foreign direct investments. Academy of Management Journal, 50(5): 1156-1168.

Tseng, C-H., Tansuhaj, P., Hallagan, W., \& McCullough, J. 2007. Effects of firm resources on growth in multinationality. Journal of International Business Studies, 38(6): 961-974.

Tsui, A.S. 2007. From homogenization to pluralism: International management research in the academy and beyond. Academy of Management Journal, 50(6): 1353-1364.

Tushman, M.L., \& Anderson, P. 1986. Technological discontinuities and organizational environments. Administrative Science Quarterly, 31(3): 439-465.

Uhlenbruck, K. Meyer, K.E., \& Hitt, M.A. 2003. Organizational Transformation in Transition Economies: Resource-Based and organizational Learning Perspectives. Journal of Management Studies, 40(2): 257282.

Uhlenbruck, K., \& Castro, J.O.D. 2000. Foreign Acquisitions in Central and Eastern Europe: Outcomes of Privatization in Transitional Economies. Academy of Management Journal, 43(3): 381-402.

Uhlenbruck, K., Rodriguez, P., Doh, J., \& Eden, L. 2006. The impact of corruption on entry strategy: Evidence from telecommunication projects in emerging economies. Organization Science, 17(3): 402414.

UNCTAD. 2004. India's outward FDI: a giant awakening? Geneva: United Nations.

UNCTAD. 2006. World investment report: FDI from developing and transition economies: Implications for development. Geneva: United Nations.

UNCTAD. 2008. World investment report: Transnational corporations, infrastructure and development. Geneva: United Nations.

Uzzi, B. 1997. Social structure and competition in interfirm networks: The paradox of embeddedness. Administrative Science Quarterly, 42: 35-67.

Verdin, P.J., \& Williamson, P.J. 1994. Core competences, competitive advantage and market analysis: Forging the links. In G. Hamel \& A. Heene (Eds.), Competence-based competition: 77-110. New York: Wiley.

Vermeulen, F., \& Barkema, H. 2002. Pace, rhythm, and scope: Process depencence in building a profitable multinational corporation. Strategic Management Journal, 23(7): 637-653. 
Vernon, R. 1966. International investment and international trade in the product cycle. Quarterly Journal of Economics, 80(2): 190-207.

Villalonga, B., McGahan, A.M. 2005. The choice among acquistions, alliances, and divestiures. Strategic Management Journal, 26: 1183-1208.

Wan, W.P. 2005. Country resource environments, firm capabilities, and corporate diversification strategies. Journal of Management Studies, 42(1): 161-182.

Wang, H., \& Schaan, J.L. 2008. How much distance do we need? Revisiting the "national cultural distance paradox". Management International Review, 48(3): 263-277.

Wei, S.J. 2000. How taxing is corruption on international investors? Review of Economics and Statistics, 82(1): $1-11$.

Wei, Y., \& Liu, X. 2006. Productivity spillovers from R\&D, exports and FDI in China's manufacturing sector. Journal of International Business Studies, 37(4): 544-557.

Wells, L.T. 1983. Third world multinationals: The rise of foreign investment from developing countries. Cambridge, MA: MIT Press.

Werner, S. 2002. Recent developments in international management research: a review of 20 top management journals. Journal of Management, 28(30): 277-305.

Wernerfelt, B. 1984. A resource-based view of the firm. Strategic Management Journal, 5(2): 171-180.

Woodward, D.P., \& Rolfe, R.J. 1993. The location of export-oriented foreign direct investment in the Caribbean basin. Journal of International Business Studies, 24(1): 121-144.

Wright, M., Filatotchev, I. Hoskisson, R.E., \& Peng, M.W. 2005. Guest editors' introduction strategy research in emerging economies: challenging the conventional wisdom. Journal of Management Studies, 42(1): 1-33.

Xin, K.R., \& Pearce, J.L. 1996. Guanxi: Connections as substitutes for formal institutional support. Academy of Management Journal, 39(6): 1641-1658.

Xu, D., \& Shenkar, O. 2002. Institutional distance and the multinational enterprise. Academy of Management Review, 27(4): 608-618.

Yamori, N. 1998. A note on the location choice of multinational banks: The Case of Japanese Financial Institutions. Journal of Banking \& Finance, 22(1): 109-120.

Yang, X., Jiang, Y., Kang, R., \& Ke, Y. 2009. A comparative analysis of the internationalization of Chinese and Japanese firms. Asia Pacific Journal of Management, 26: 141-162.

Yeung, H.W.C. 1994. Third world multinationals revisited: A research critique and future agenda. Third World Quarterly, 15: 297-317.

Yeung, H.W.C. 1998. The political economy of transnational corporations: a study of the regionalization of Singaporean firms. Political Geography, 17(4): 389-416.

Yeung, H.W.C. 2000. The globalization of business firms from emerging economies. Chetenham, UK.: Edward Elgar. 
Yu, C.J., \& Ito, K. 1988. Oligopolistic reaction and foreign direct investment : The case of the U.S. tire and textiles industries. Journal of International Business Studies. 19(3): 449-460.

Zaheer, S. 1995. Overcoming the liability of foreignness. Academy of Management Journal, 38(2): 341363.

Zaheer, S., \& Mosakowski, E. 1997. The dynamics of the liability of foreignness: A global study of survival in financial services. Strategic Management Journal, 18(6): 439-464.

Zahra, S.A. 2003. International expansion of US manufacturing family businesses: the effect of ownership and involvement. Journal of Business Venturing, 18(4): 495-512.

Zhao, D., Delios, A., \& Yang, J.Y. 2002. Location determinants of Japanese foreign direct investment in China. Asia Pacific Journal of Management, 19: 63-86.

Zhao, H., \& Zhu, G. 2000. Location factors and country-of-origin differences: An empirical analysis of FDI in China. Multinational Business Review, 8(1): 60-73.

Zhou, X.G. 2000. Economic transformation and income inequality in urbn china: Evidence from panel data. American Journal of Sociology, 105(4): 1135-1174. 


\section{APPENDIX 1}

\section{LIST OF COUNTRIES CLASSIFIED AS EMERGING MARKETS IN DISSERTATION}

Asia

Bangladesh

China

India

Indonesia

Israel

Jordan

Malaysia

Mauritius

Pakistan

Philippines

Saudi Arabia

Sri Lanka

South Korea

Taiwan

Thailand

Europe

Albania

Armenia

Azerbijan

Belarus

Bosnia \& Herzegovina

Bulgaria

Croatia

Czech Republic 
Estonia

Georgia

Greece

Hungary

Kazakhstan

Kyrgystan

Latvia

Lithuania

Macedonia

Moldova

Poland

Portugal

Romania

Russia

Slovakia

Slovenia

Tajikstan

Turkey

Turkmenistan

Ukraine

Uzbekistan

Latin America

Argentina

Brazil

Chile

Colombia

Ecuador 
Jamaica

Mexico

Peru

Trinidad \& Tobago

Venezuela

Africa

Botswana

Cote d'Ivoire

Egypt

Ghana

Kenya

Morocco

Nigeria

South Africa

Tunisia

Zimbabwe 
VITA

\section{NAVEEN KUMAR JAIN}

$1987-90$

1992-94

1994-2005

2006-2009
B.Sc. Honors, Chemistry

Delhi University

Delhi, India

P.G.D.M

Indian Institute of Management

Bangalore, India

worked in corporate India with various organizations

Doctoral Candidate in Business Administration

Florida International University

Miami, Florida

\section{PUBLICATIONS \& PRESENTATIONS}

Jain, N.K., Kundu, S.K., \& Niederman, F. 2008. Offshoring propensity in information technology services: A firm and country level analysis. Management International Review, 48(4): 447-461.

Jain, N.K. Resources, strategies and FDI determinants of emerging market firms. Academy of Management, Chicago, 2009.

Jain, N.K. Resources, strategies, location determinants, and host country location choice by emerging market firms. Accepted for presentation at the Strategic Management Society, Washington D.C., 2009.

Jain, N.K., \& Kundu, S.K. Resources, strategies and host country location choice of emerging market firms. Academy of International Business, San Diego, 2009.

Jain, N.K., Kumar, V., Kundu, S.K., \& Zahra, S. The limits of our Knowledge: Competing in emerging markets. Strategic Management Society, Cologne, 2008.

Jain, N.K., Kumar, V., \& Kundu, S.K. Internationalization of emerging market firms: Search for new direction. Academy of Management, Anaheim, 2008.

Kumar, V., Perdersen, T., Kundu, S.K., \& Jain, N.K. Business group affiliation and internationalization of emerging market firms. Academy of Management, Anaheim, 2008.

Jain, N.K., Kundu, S.K., \& Niederman, F. Offshoring propensity in information technology: The interaction of firm imitative behavior \& host country capacity. Academy of International Business, Milan, 2008.

Schneper, W.D., Celo, S., \& Jain, N.K. 2008. Agents, altruism and corporate governance: The impact of family ownership on non-executive compensation and training. Proceedings of the American Society of Business and Behavioral Sciences, 15(1): 1340-1352.

Kundu, S.K., Jain, N.K., \& Niederman, F. Explaining propensity toward offshoring in information technology industry: A firm and country level analysis. Academy of International Business, Indianapolis, 2007. 